\title{
Methods for Adjusting U.S. Geological Survey Rural Regression Peak Discharges in an Urban Setting
}
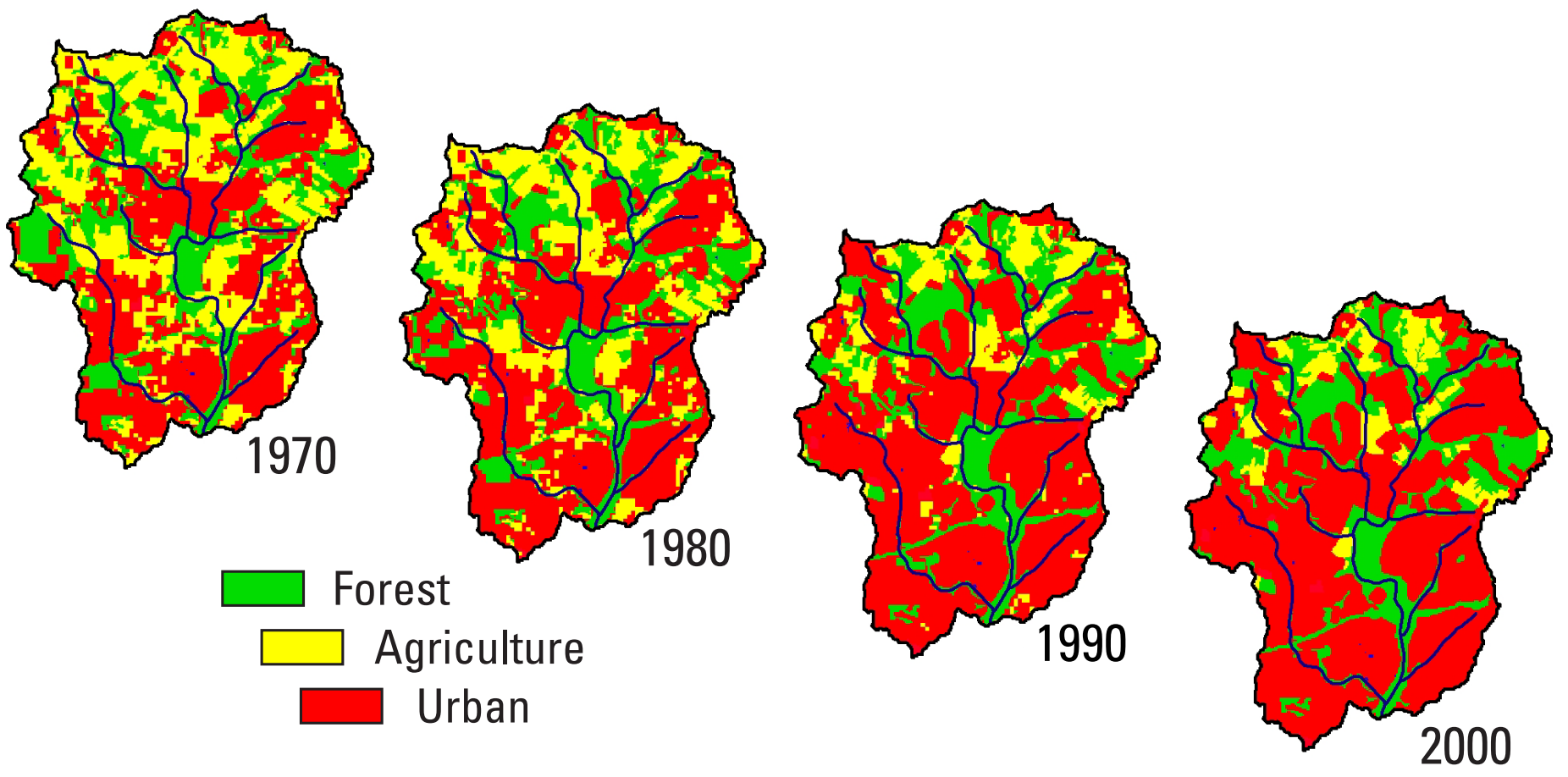

Scientific Investigations Report 2006-5270 
Cover. Land use change in the Northwest Branch Anacostia River near Colesville, Maryland (USGS streamgage 01650500). The images show the progression of urban development in this watershed over the period 1970 to 2000. 


\section{Methods for Adjusting U.S. Geological Survey Rural Regression Peak Discharges in an Urban Setting}

By Glenn E. Moglen and Dorianne E. Shivers

Scientific Investigations Report 2006-5270 


\section{U.S. Department of the Interior \\ Gale A. Norton, Secretary \\ U.S. Geological Survey \\ Mark D. Meyers, Director}

U.S. Geological Survey, Reston, Virginia: 2005

For more information about the USGS and its products:

Telephone: 1-888-ASK-USGS

World Wide Web: http://www.usgs.gov/

\footnotetext{
Any use of trade, product, or firm names in this publication is for descriptive purposes only and does not imply endorsement by the U.S. Government.

Although this report is in the public domain, permission must be secured from the individual copyright owners to reproduce any copyrighted materials contained within this report.

Suggested citation:

Moglen, G.E. and Shivers, D.E., 2006, Methods for Adjusting U.S. Geological Survey Rural Regression Peak Discharges in an Urban Setting: Reston, Virginia, U.S. Geological Survey, Scientific Investigations Report 2006-5270, 55 p.
} 


\section{Contents}

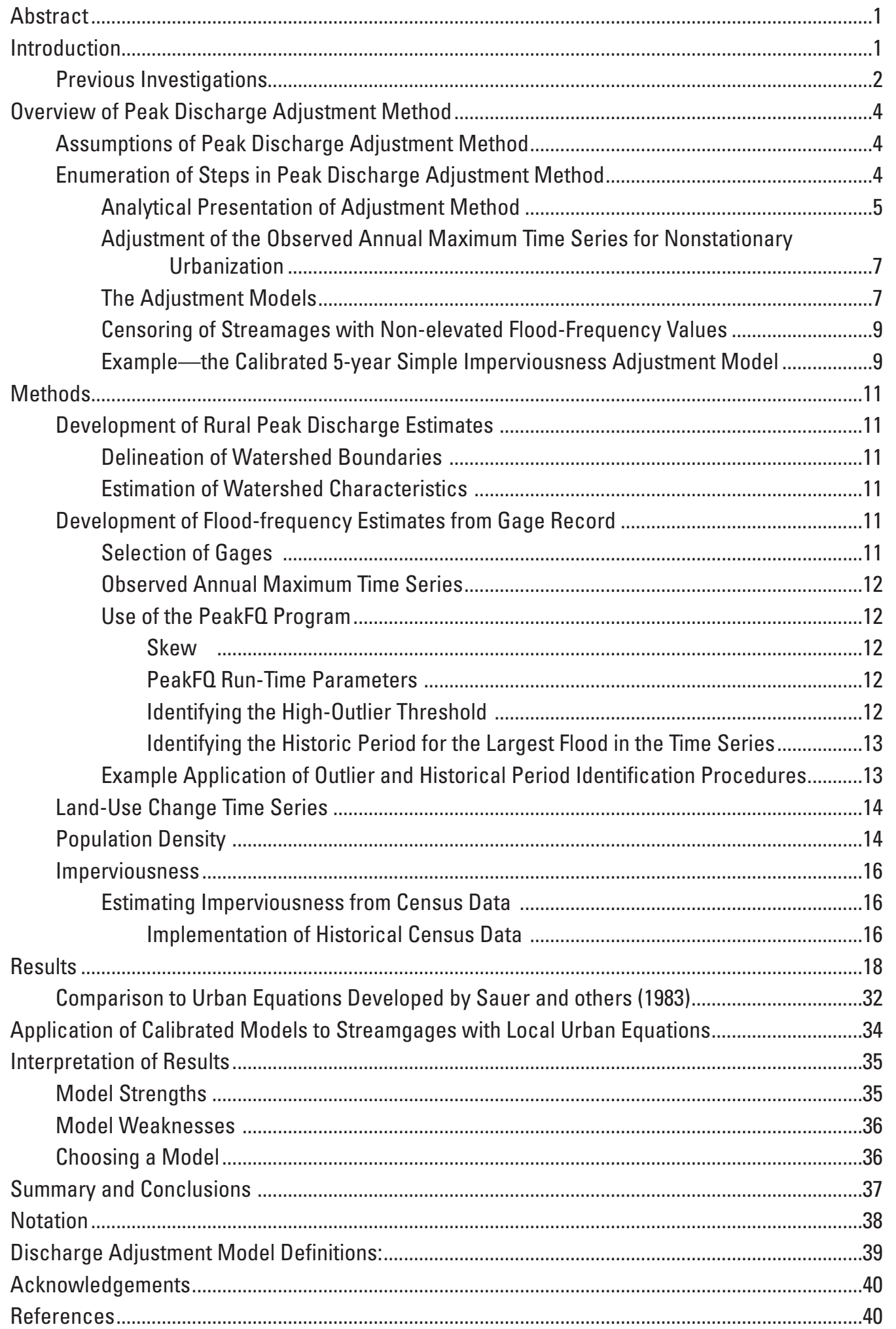




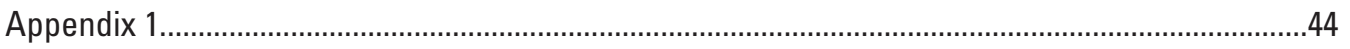

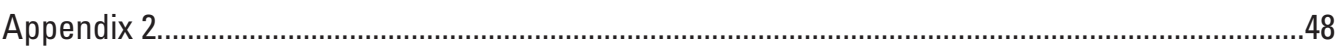

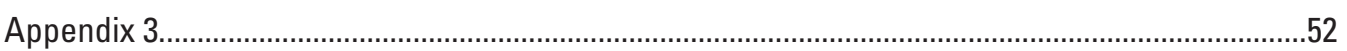

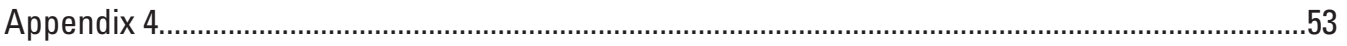

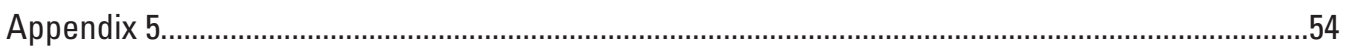

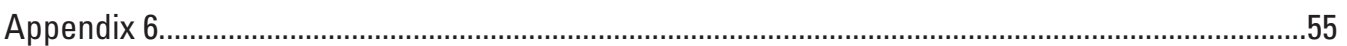

\section{Figures}

Figure 1. Locations of urban and rural streamgages used in current (2006) study of rural regression peak discharges.........................................................................................

Figure 2. Flow chart for the process for calibrating adjustment equations..................................6

Figure 3. The relation between observed and scaled imperviousness for the scaled vales of $I^{*}=12.1$ and $\boldsymbol{c}_{4}=0.2$.

Figure 4. Annual maximum time series for U.S. Geological Survey streamgage 02037800, Falling Creek near Midlothian, Virginia.

Figure 5. Population density in Montgomery County, Maryland, as a function of census tract area from the 2000 census.

Figure 6. Distribution of population density as a fraction of the total watershed area for U.S. Geological Survey streamgage 01645000, Seneca Creek at Dawsonville, Maryland.15

Figure 7. Relations of imperviousness to population density as measured by Stankowski (1972) and as measured in this study.

Figure 8. Estimated imperviousness from census tract data for U.S. Geological Survey streamgage 01645000, Seneca Creek at Dawsonville, Maryland.

Figure 9. Application of the $(A)$ simple imperviousness model, $(B)$ imperviousness distribution model, and $(C)$ scaled imperviousness model to the ratio of urban to rural discharges as a function of return period and imperviousness at U.S. Geological Survey streamgage 01645000, Seneca Creek at Dawsonville, Maryland.

Figure 10. Application of the (A) simple density model, $(B)$ density distribution model, and (C) scaled density model to the ratio of urban to rural discharges as a function of return period and imperviousness at U.S. Geological Survey streamgage 01645000, Seneca Creek at Dawsonville, Maryland.

Figure 11. Application of the (A) simple imperviousness model, $(B)$ imperviousness distribution model, and $(C)$ scaled imperviousness model to the ratio of urban to rural discharges as a function of return period and imperviousness at U.S. Geological Survey streamgage 01585200, West Branch Herring Run at Idlewylde, Maryland. ...30

Figure 12. Application of the (A) simple density model, $(B)$ density distribution model, and (C) scaled density model to the ratio of urban to rural discharges as a function of return period and imperviousness at U.S. Geological Survey streamgage 01585200, West Branch Herring Run at Idlewylde, Maryland. 


\section{Tables}

Table 1. Example of the adjustment of the observed annual maximum time series using the 5-year simple imperviousness adjustment model for U.S. Geological Survey streamgage 01645000, Seneca Creek at Dawson, Maryland.

Table 2. Number of gages used in the regression analysis as a function of return period......18

Table 3. Goodness-of-fit characteristics for the models evaluated.........................................19

Table 4. Calibrated values of the adjustment model coefficients and exponents.....................20

Table 5. Rankings of model performance based on the goodness-of-fit values shown in table 3 .

\section{0}

Table 6. Summed rankings of model calibration statistics based on goodness-of-fit values

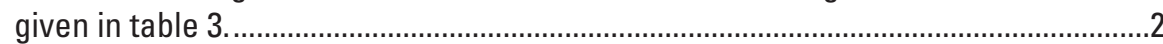

Table 7. Smoothed values of the adjustment model coefficients and exponents.....................23

Table 8. Performance of U.S. Geological Survey urban equations from an earlier study and urban equations developed in this report.......................................................................33

Table 9. Relative Standard error $\left(S_{\mathrm{e}} / S_{\mathrm{y}}\right)$ for three imperviousness models developed in this report as normalized by the relative standard error determined by Sauer and others (1983).

Table 10. Mean bias, in cubic feet per second, for new urban equations used on data from 10 U.S. Geological Survey streamgages for which localized urban equations are available.

Table 11. Relative standard error $\left(S_{\mathrm{e}} / S_{\mathrm{y}}\right)$ for new urban equations used on data from 10 U.S. Geological Survey streamgages for which localized urban equations are available.... 35

Table 12. Summed and ranked overall performance of new urban equations used on data from 10 U.S. Geological Survey streamgages for which localized urban equations are available. 


\section{Conversion Factors}

Inch/Pound to SI

\begin{tabular}{|c|c|c|}
\hline Multiply & By & To obtain \\
\hline \multicolumn{3}{|c|}{ Length } \\
\hline inch (in.) & 2.54 & centimeter $(\mathrm{cm})$ \\
\hline inch (in.) & 25.4 & millimeter $(\mathrm{mm})$ \\
\hline \multicolumn{3}{|c|}{ Area } \\
\hline square mile $\left(\mathrm{mi}^{2}\right)$ & 259.0 & hectare (ha) \\
\hline square mile $\left(\mathrm{mi}^{2}\right)$ & 2.590 & square kilometer $\left(\mathrm{km}^{2}\right)$ \\
\hline \multicolumn{3}{|c|}{ Flow rate } \\
\hline cubic foot per second $\left(\mathrm{ft}^{3} / \mathrm{s}\right)$ & 0.02832 & cubic meter per second $\left(\mathrm{m}^{3} / \mathrm{s}\right)$ \\
\hline \multicolumn{3}{|c|}{ Hydraulic gradient } \\
\hline foot per mile (ft/mi) & 0.1894 & meter per kilometer $(\mathrm{m} / \mathrm{km})$ \\
\hline
\end{tabular}

Temperature in degrees Celsius $\left({ }^{\circ} \mathrm{C}\right)$ may be converted to degrees Fahrenheit $\left({ }^{\circ} \mathrm{F}\right)$ as follows:

$$
{ }^{\circ} \mathrm{F}=\left(1.8 x^{\circ} \mathrm{C}\right)+32
$$

Temperature in degrees Fahrenheit $\left({ }^{\circ} \mathrm{F}\right)$ may be converted to degrees Celsius $\left({ }^{\circ} \mathrm{C}\right)$ as follows:

$$
{ }^{\circ} \mathrm{C}=\left({ }^{\circ} \mathrm{F}-32\right) / 1.8
$$

Vertical coordinate information is referenced to the North American Vertical Datum of 1988 (NAVD 88).

Horizontal coordinate information is referenced to the North American Datum of 1983 (NAD 83).

Altitude, as used in this report, refers to distance above the vertical datum.

The following SI unit of measure is given in this report in reference to impervious mapping resolution.

\begin{tabular}{l|c|c}
\hline Multiply & By & To obtain \\
\hline \multicolumn{2}{c|}{ Length } \\
\hline meter $(\mathrm{m})$ & 3.281 & foot $(\mathrm{ft})$ \\
\hline
\end{tabular}




\title{
Methods for Adjusting U.S. Geological Survey Rural Regression Peak Discharges in an Urban Setting
}

\author{
By Glenn E. Moglen and Dorianne E. Shivers ${ }^{1}$
}

\begin{abstract}
A study was conducted of 78 U.S. Geological Survey gaged streams that have been subjected to varying degrees of urbanization over the last three decades. Flood-frequency analysis coupled with nonlinear regression techniques were used to generate a set of equations for converting peak discharge estimates determined from rural regression equations to a set of peak discharge estimates that represent known urbanization. Specifically, urban regression equations for the 2-, 5-, 10-, 25-, 50-, $100-$, and 500-year return periods were calibrated as a function of the corresponding rural peak discharge and the percentage of impervious area in a watershed. The results of this study indicate that two sets of equations, one set based on imperviousness and one set based on population density, performed well. Both sets of equations are dependent on rural peak discharges, a measure of development (average percentage of imperviousness or average population density), and a measure of homogeneity of development within a watershed. Average imperviousness was readily determined by using geographic information system methods and commonly available land-cover data. Similarly, average population density was easily determined from census data. Thus, a key advantage to the equations developed in this study is that they do not require field measurements of watershed characteristics as did the U.S. Geological Survey urban equations developed in an earlier investigation.

During this study, the U.S. Geological Survey PeakFQ program was used as an integral tool in the calibration of all equations. The scarcity of historical land-use data, however, made exclusive use of flow records necessary for the 30-year period from 1970 to 2000. Such relatively short-duration streamflow time series required a nonstandard treatment of the historical data function of the PeakFQ program in comparison to published guidelines. Thus, the approach used during this investigation does not fully comply with the guidelines set forth in U.S. Geological Survey Bulletin 17B, and modifications may be needed before it can be applied in practice.
\end{abstract}

\section{Introduction}

The U.S. Geological Survey (USGS) maintains and publishes a set of rural regression equations for use in estimating peak discharges of varying return periods for each State in the United States (U.S.; Jennings and others, 1994; Ries and Crouse, 2002). Sauer and others (1983) developed a method for transforming these rural discharge estimates to estimates for urban watersheds based on several watershed characteristics, most notably two different indices of urbanization - the basin development factor (BDF) and the percentage of impervious area. A study was conducted to reassess the method of Sauer and others (1983) by taking advantage of 20 additional years of streamflow data, using geographic information system (GIS) data and techniques, and considering new approaches in the development of a set of urban regression equations. As in the earlier study, the goal of this study was to develop flood-frequency equations for urbanized sites by applying urban adjustments to the $T$-year flood values obtained from the regional equations for rural ungaged sites. The $T$-year flood is the flood that, on average, is equaled or exceeded once in any given number $(T)$ of years.

The USGS typically conducts flood-frequency analyses consistent with Bulletin 17B (Interagency Advisory Committee on Water Data, 1982). For the study, the USGS flood-frequency analysis program, PeakFQ, was incorporated into an optimization program to calibrate several sets of urban regression equations. Because of limited-duration streamflow time series used in the analysis, however, the approach used in this study for the historical period input to the PeakFQ program does not comply with Bulletin 17B guidelines.

\footnotetext{
${ }^{1}$ University of Maryland, Department of Civil and Environmental Engineering, College Park, MD 20742.
} 


\section{Previous Investigations}

The effects of land-use changes on stream discharge are well documented (for example Carter, 1961; James, 1965; Viessman, 1966; Leopold, 1968; Andersen, 1970). The effects of urbanization, in particular, typically are related to characteristic changes in watersheds. Urbanization generally is associated with increased areas of impervious surfaces, such as pavement and rooftops. These surfaces usually have drainage features that quickly convey water away from structures or road surfaces and into nearby streams. In addition, urbanization generally reduces temporary stormwater storage, such as depression storage and tree-leaf interception. These urbanization processes create large volumes of stormwater that generally travel swiftly to the surface-drainage network and result in high flood peaks, which are the focus of this study.

Sauer and others (1983) presented a regression-equation approach of using rural flood-frequency estimates, such as those resulting from the equations summarized by Jennings and others (1994), and scaling these estimates upwards based on several measures of urbanization. Such rural flood-frequency estimates are currently (2006) calculated using the USGS National FloodFrequency Program (version 3; Ries and Crouse, 2002).

Although Sauer and others (1983) calibrated several different sets of adjustment equations, their best model included seven parameters as presented in the following form:

$$
U Q_{T}=c_{1, T} A^{c_{2, T}} S L^{c_{3, T}}(R I 2+3)^{c_{4, T}}(S T+8)^{c_{5, T}}(13-B D F)^{c_{6, T}} I A^{c_{7, T}} R Q_{T}^{c_{8, T}},
$$

where $U Q_{T} \quad$ is the $T$-year urban peak discharge, in cubic feet per second;

$A$ is the drainage area, in square miles;

$S L \quad$ is the main channel slope, in foot per mile;

$R I 2$ is the 2-hour, 2-year rainfall, in inches;

$S T$ is the basin storage in percent;

$B D F$ is the basin development factor (an urbanization index that quantifies channel improvements, channel linings, storm drains/sewers, and curb-and-gutter streets);

$I A \quad$ is the impervious area, in percent; and

$R Q_{T} \quad$ is the $T$-year rural discharge as predicted from the appropriate USGS rural-regression equation.

(Note: The difficulty in determining the BDF index based solely on remotely sensed data was a motivating factor for conducting this study.)

In some States, the USGS has developed localized urban equations that supersede the use of the national urban equations developed by Sauer and others (1983; shaded areas in fig. 1). The localized urban equations vary in sophistication, but all generally require some measure of urbanization, such as the percentage of impervious or residential area. The general equations for the States of New Jersey (Stankowski, 1974), Pennsylvania (Stuckey and Reed, 2000), and Wisconsin (Conger, 1986) are presented here to illustrate the available range of localized urban equations.

\section{New Jersey:}

$$
Q_{T}=c_{1, T} A^{c_{2, T}} S L^{c_{3, T}} S T^{c_{4, T}} I A^{c_{5, T}}
$$

where $Q_{T} \quad$ is the $T$-year urban peak discharge, in cubic fet per second;

$A \quad$ is the drainage area, in square miles;

$S L \quad$ is the channel slope, in foot per mile;

$S T \quad$ is the basin storage, such as lakes and swamps, in percent; and

IA is the impervious area, in percent, based on population density.

Pennsylvania (Region A):

$$
Q_{T}=c_{1, T} A^{c_{2, T}}(1+0.01 F)^{c_{2, T}}(1+0.01 U)^{c_{2, T}}(1+0.01 C)^{c_{3, T}}(1+0.01 C A)^{c_{4, T}},
$$

where $Q_{T} \quad$ is the $T$-year urban peak discharge, in cubic feet per second;

$A$ is the drainage area, in square miles;

$F \quad$ is forest cover, in percent;

$U$ is urban development, in percent;

$C \quad$ is the watershed, in percent, underlain by carbonate rock; and

$C A$ is the watershed, in percent, controlled by lakes, swamps, or reservoirs. 


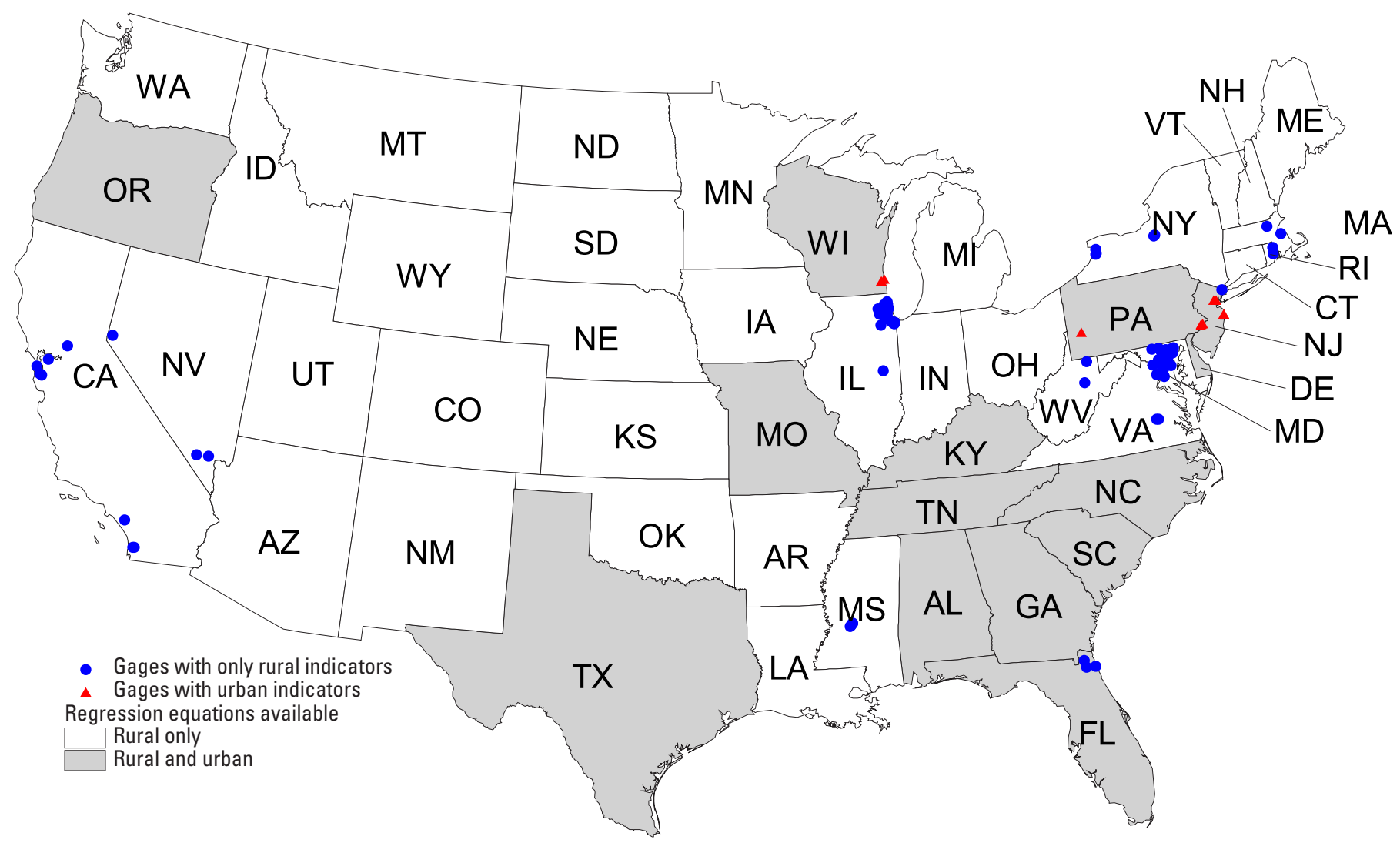

Figure 1. Locations of urban and rural streamgages used in current (2006) study of rural regression peak discharges. [Shaded states have urban prediction regression equations that apply either statewide or in selected areas.]

$\underline{\text { Wisconsin (Milwaukee County urban areas): }}$

$$
Q_{T}=c_{1, T} A^{c_{2, T}} I A^{c_{3, T}},
$$

where $Q_{T} \quad$ is the $T$-year urban peak discharge, in cubic feet per second;

$A$ is the drainage area, in square miles; and

IA is the impervious area, in percent. 


\section{Overview of Peak Discharge Adjustment Method}

The central premise of the study is that observed peak discharges at USGS streamgages are a function of watershed characteristics that exist at the time of the observed flood. Specifically, urbanization, measured as impervious area, varies over time and needs to be properly accounted for when performing flood-frequency analysis on an observed annual maximum time series.

\section{Assumptions of Peak Discharge Adjustment Method}

- Assumption 1: The USGS rural regression equations for a State or region represent the best estimate of rural discharges for that particular location.

- Assumption 2: In a watershed undergoing urbanization, the observed flood peak in any given year $(t)$ depends on the amount of impervious area in the watershed. Because urbanization is an ongoing process, it may be necessary to obtain annual time series of impervious areas in rapidly changing watersheds.

- Assumption 3: At streamgages influenced by urbanization, the observed annual maximum time series can be adjusted downward to be consistent with the predicted flood frequency obtained by applying the USGS rural regression equations for the gage location.

- Assumption 4: The equations used to adjust the observed annual maximum time series can be inverted for use in scaling a USGS rural flood-frequency regression equation upward to account for urbanization effects. (Note: The objective function of a regression equation can be minimized only in the form in which it was calibrated, and the inversion process may cause a loss in optimality of the objective function.)

- Assumption 5: Because calibrated coefficients and exponents vary with each return period, separate optimizations are required for each return period considered. This assumption is consistent with the approach in Sauer and others (1983), which produced different coefficients and exponents for each return period.

- Assumption 6: Stormwater-management methods either are not present or do not have a measurable effect on flooding caused by urbanization. Although stormwater-management methods can mitigate increased flooding caused by urbanization, much of the urbanization quantified in this report predates the implementation of stormwater-management methods. Therefore, this report does not attempt to quantify any effects from implementing stormwater-management methods.

\section{Enumeration of Steps in Peak Discharge Adjustment Method}

The general steps in the adjustment method steps are described here. Because this is a calibration exercise, the process outlined here is iterative and is dependent on the minimization of an objective function that quantifies the difference between the observed rural flood-frequency values and the flood-frequency results obtained by using the PeakFQ program and adjusted annual maximum discharge data for urban streams.

Step 1. Assume (a) a functional form for an adjustment equation and (b) initial trial values for the coefficients and exponents of this adjustment equation.

Step 2. Adjust the annual maximum time series for the selected gage $(i)$ as a function of the observed annual maximum time series and the impervious area time series. This produces an adjusted annual maximum time series.

Step 3. Write the adjusted annual maximum time series in the USGS National Water Data Storage and Retrieval System (WATSTORE) format.

Step 4. Use the PeakFQ program to determine the flood-frequency distribution at the selected gage $(i)$ for the adjusted time series.

Step 5. Scan the output of the PeakFQ program for the $T$-year flood and incrementally adjust the objective function by the squared difference between the PeakFQ $T$-year flood and the rural regression value for the same flood-frequency. (Note that these differences will be in the logarithmic space to give similar weight to both small and large watersheds.)

Step 6. Modify the trial coefficients and exponents assumed in Step 1. 
Steps 2 through 6 are repeated for all gages in the database and then performed iteratively until the objective function described in Step 5 is minimized. The entire process is conducted separately for the 2-, 5-, 10-, 25-, 50-, 100-, and 500-year flood-frequencies. A detailed flow chart of the general process described here is shown in figure 2. (Note: Steps 2-6 are automated by a nonlinear optimization program modified from McCuen (1993). The objective function that is minimized is the sum of the squared errors between the PeakFQ output for the $T$-year flood and the equivalent $T$-year flood estimated by the rural regression equation.)

After an equation is calibrated for each return period, the calibrated urban equation is determined in the following step (7):

Step 7. Substitute the calibrated coefficients from the urban-to-rural adjustment function ( $f$-inverse) into the original ruralto-urban function $(f)$.

From the user's standpoint, there likely is only an interest in the actual use of the function $f$ from Step 7. The user's experience will be limited to the following two steps:

1) Using the National Flood-Frequency (NFF) program (Ries and Crouse, 2002) or direct application of the USGS rural regression equation, estimate the rural flood-frequency for the ungaged location; and

2) Use the rural-to-urban function $(f)$, transform rural $T$-year floods (from the rural regression equations previously determined) into corresponding $T$-year urban floods.

A critical challenge is the determination of the appropriate annual maximum discharge adjustment equation. The approach used during this study was to explore several functional forms and select the form that produced the best goodness-of-fit statistics across all frequencies.

\section{Analytical Presentation of Adjustment Method}

Pursuant to Bulletin 17B (Interagency Advisory Committee on Water Data, 1982), $F F\left(x, Q_{o}, H P, S S\right)$ is defined as the flood-frequency operator. This operator returns the flood-frequency vector, $\left(Q_{f f}\right.$ for the 2-, 5-, 10-, 25-, 50-, 100-, and 500-year floods) for a time series of annual maximum floods $(x)$, for an identified high-outlier discharge threshold $\left(Q_{o}\right)$, for a historical return period associated with the largest flood exceeding $Q_{o}(H P)$, and assuming the station skew option (SS). An individual member of the flood-frequency vector, say the $T$-year flood, is identified as $Q_{f t}(T)$ or $Q_{T}$.

The observed annual maximum time series is defined as $Q_{o b s}(t)$. The adjusted annual maximum time series is defined as $Q_{a d j}(t)$. Performing flood-frequency analyses on these two time series produced the flood-frequency vectors, $Q_{f f, o b s}$ and $Q_{f f ; a d j}$, respectively. Thus, the resulting equations take the following forms:

$$
Q_{f f, o b s}=F F\left(Q_{o b s}(t), Q_{o}, H P_{o b s}, S S\right),
$$

and

$$
Q_{f f, a d j}=F F\left(Q_{a d j}(t), Q_{o} H P_{a d j}, S S\right),
$$

where $H P_{o b s}$ and $H P_{a d j}$ are the return periods associated with the largest floods in the respective annual maximum time series exceeding $Q_{o}$. For simplification, the dependency of the flood-frequency operator on a high-outlier threshold, a specified historical period, and a skew option was omitted from the notation. Thus, equations 5 and 6 , respectively, reduce to simpler forms:

$$
Q_{f f, o b s}=F F\left[Q_{o b s}(t)\right] \text {, }
$$

and

$$
Q_{f f, a d j}=F F\left[Q_{a d j}(t)\right] .
$$

Two other flood-frequency vectors were relevant to this study- $Q_{f \text { frural }}$ and $Q_{f f \text {, urban }}$, which are the rural and urban floodfrequency vectors, respectively. Because these vectors are determined from regression equations, they exist only as flood-frequency values and have no time series directly associated with them. 


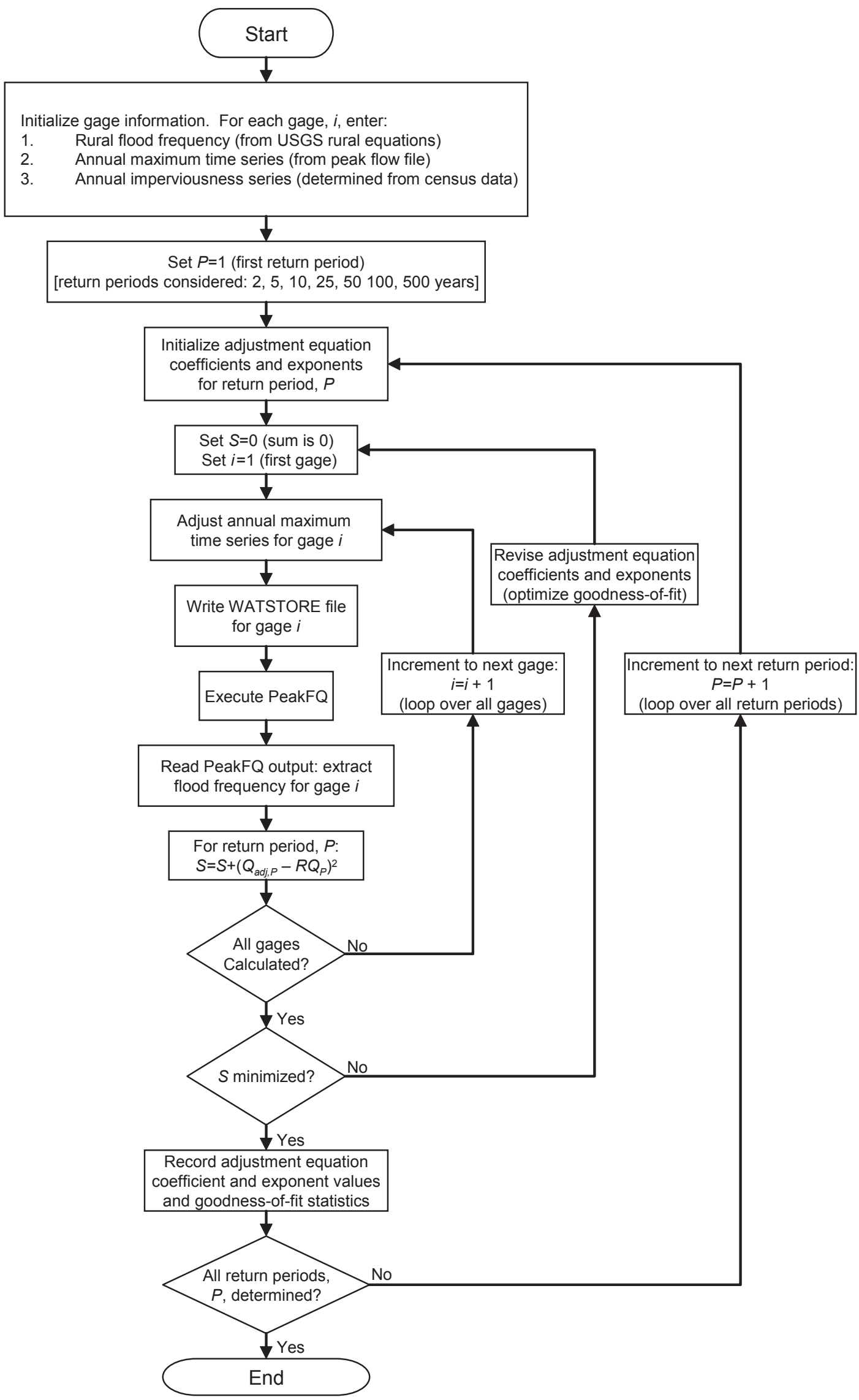

Figure 2. Flow chart for the process for calibrating adjustment equations. 


\section{Adjustment of the Observed Annual Maximum Time Series for Nonstationary Urbanization}

A central premise in the study by Sauer and others (1983) was that the observed flood-frequency record for a selected streamgage was stationary; in othet words, the record was unaffected by changes in urbanization over the period of record analyzed. To compensate for this premise, Sauer and others (1983) applied the rule that a streamgage record was usable if the amount of impervious area in the watershed had not increased more than 50 percent during the period of record.

In the current (2006) study, a different approach was taken. As discussed previously, an annual time series of impervious area, $I A(t)$, was developed for each gage studied in order to relate a unique value of impervious area to each observed annual maximum flood value.

The observed and adjusted annual maximum time series are related by a set of nonlinear functions, $f_{T}($.$) , such that$

$$
Q_{a d j, T}(t)=f_{T}\left[Q_{o b s}(t), I A(t)\right]
$$

where $Q_{a d j, T}(t)$ is the adjusted time series of annual maximum flows that is keyed to the $T$-year flood. Each of the seven equations for the 2-, 5-, 10-, 25-, 50-, 100-, and 500-year floods $\left(f_{2}, f_{5}, f_{10}, f_{25}, f_{50}, f_{100}\right.$, and $f_{500}$, respectively) must be calibrated.

When the flood-frequency operator is applied to each adjusted time series, it produces the rural flood-frequency value for the return period, $(T)$ :

$$
Q_{f f, \text { rural }}(T)=R Q_{T}=F F\left\{f_{T}\left[Q_{o b s}(t), I A(t)\right]\right\}
$$

Once all $f_{T}($.$) are determined and assumption 4$ was applied, these functions were inverted such that the independent variables were the rural flood-frequency values and impervious area, and the dependent variable was the urban flood-frequency value:

$$
Q_{f f, \text { urban }}(T)=U Q_{T}=f_{T}^{-1}\left[Q_{f f, \text { rural }}(T), I A\right],
$$

where $f_{T}^{-1}($.$) is the inverted form of f_{T}($.$) .$

\section{The Adjustment Models}

Several forms of $f_{T}($.$) were investigated - the null model, the simple imperviousness model, the simple density model, the$ imperviousness distribution model, the density distribution model, the scaled imperviousness model, and the scaled density model. These model forms are represented by the following equations (12 - 18, respectively).

Null model:

$$
Q_{a d j, T}(t)=c_{1, T}\left[Q_{o b s}(t)\right]^{c_{2, T}}
$$

Simple imperviousness model:

$$
Q_{a d j, T}(t)=\frac{c_{1, T}\left[Q_{o b s}(t)\right]^{c_{2, T}}}{[I A(t)+1.0]^{c_{3, T}}} .
$$

Simple density model:

$$
Q_{a d j, T}(t)=\frac{c_{1, T}\left[Q_{o b s}(t)\right]^{c_{2, t}}}{[P D(t)+0.001]^{c_{3, T}}}
$$

Imperviousness distribution model:

$$
Q_{a d j, T}(t)=\frac{c_{1, T}\left[Q_{o b s}(t)\right]^{c_{2, T}}[\Delta I A(t)+0.01]^{c_{4, T}}}{[I A(t)+0.01]^{c_{3, T}}} .
$$

Density distribution model:

$$
Q_{a d j, T}(t)=\frac{c_{1, T}\left[Q_{o b s}(t)\right]^{c_{2, T}}[\Delta P D(t)+0.001]^{c_{4, T}}}{[P D(t)+0.001]^{c_{3, T}}} .
$$


Scaled imperviousness model:

$$
Q_{\text {adj }, T}(t)=\frac{c_{1, T}\left[Q_{o b s}(t)\right]^{c_{2, T}}}{\left[1+\frac{99}{1+e^{c_{4, T}\left\{I_{T}^{*}-(I A(t)\}\right.}}\right]^{c_{3, T}}}
$$

Scaled density model:

$$
Q_{\text {adj }, T}(t)=\frac{c_{1, T}\left[Q_{o b s}(t)\right]^{c_{2, T}}}{\left[1+\frac{99}{1+e^{c_{4, T}\left\{P D_{T}^{*}-(P D(t)\}\right.}}\right]^{c_{3, T}}}
$$

The "distribution" models (eqs. 15 and 16) deserve a brief discussion. The terms $\triangle I A(t)$ and $\triangle P D(t)$ represent the difference between the $10^{\text {th }}$ and $90^{\text {th }}$ percentiles of the impervious area and population density, respectively. These terms quantify the homogeneity or uniformity of development within a watershed. Watersheds with relatively small values of either of these terms are considered to be uniform. Consideration of uniformity of development is helpful in predicting flood behavior.

The "scaled" models (eqs. 17 and 18) also deserve a brief explanation. The term "scaled imperviousness" varies nonlinearly from 1 to 100 as $I A$ increases from 0 to 100 percent. For $I A=I^{*}$, the scaled imperviousness equals 50.5 . The scaled imperviousness function for typical parameter values is shown in figure 3 . Scaled imperviousness is used because it could be argued that each incremental increase in imperviousness may not have an equivalent effect on flood-frequency. In figure 3 , the effect of imperviousness increases most rapidly within the range of 5 to 15 percent imperviousness. This is consistent with studies of the effects of imperviousness on ecological health (for example, Schueler, 1987).

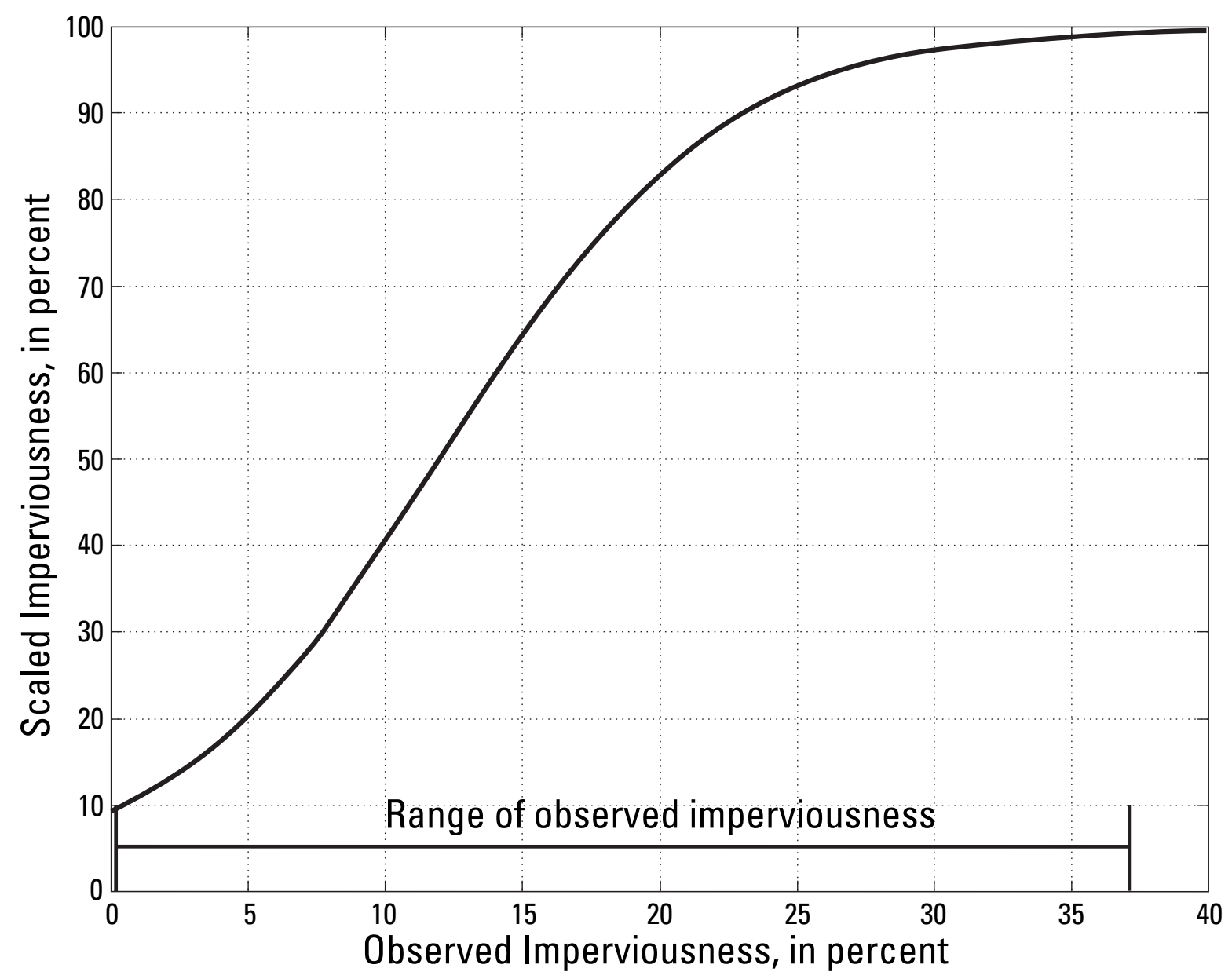

Figure 3. The relation between observed and scaled imperviousness for the scaled vales of $I^{*}=12.1$ and $c_{4}=0.2$. 


\section{Censoring of Streamages with Non-elevated Flood-Frequency Values}

Using PeakFQ, a preliminary flood-frequency analysis was performed for the observed annual maximum time series at each of the 78 streamgages. These analyses were conducted identically to those that are conducted in the optimization model with respect to identifying high outliers and determining the length of the historical record (discussed later). The flood-frequency results from these preliminary analyses were compared with the rural regression flood-frequency values described later in this report. If, at a specific streamgage, the flood-frequency from the observed annual maximum time series produced estimates for the $T$-year flood such that

$$
Q_{f f, o b s}(T)<Q_{f f, \text { rural }}(T),
$$

this gage was eliminated from the database for the development of the $T$-year regression equation. The rationale for such data elimination is that if a streamgage does not have an increase in flood-frequency values relative to the rural regression equations for peak flows, then it does not make sense to use such a gage to calibrate an urban-scaling factor. The number of gages censored from the analysis will be presented later in the "Results" section.

\section{Example - the Calibrated 5-year Simple Imperviousness Adjustment Model}

As an example of the flow-adjustment process, consider the calibrated form for the 5-year, simple imperviousness adjustment model determined in this study:

$$
f_{5}=0.331\left[Q_{o b s}(t)\right]^{1.15}[I A(t)+1.0]^{-0.173}
$$

Included in table 1 are the imperviousness time series, $I A(t)$, the observed annual maximum time series, $Q_{\text {obs }}(t)$, and the 5-year adjusted annual maximum time series, $Q_{a d j, 5}(t)$ for USGS streamgage 01645000, Seneca Creek at Dawsonville, Maryland. The far right column of the table contains the ratios of the adjusted discharges to the observed discharges. Notice that the ratios are less than 1 for all by the three largest discharges in 1971, 1972, and 1975, indicating that the adjusted annual maximum time series generally is less than the observed annual maximum time series, which would be expected if the adjusted series approximates the comparatively small rural discharges that would have occurred in these years had urbanization not occurred. The adjustment ratios also are clearly smaller for smaller discharges and approach (and slightly exceed) 1 as the discharges become large. This indicates that relatively small discharges that correspond to more frequent 2- and 5-year flows are subject to adjustment from the effects of imperviousness. Such adjustments are consistent with the expectation that urbanization has the greatest effect on flood flows from storms of small magnitude. Further, in general, note that the adjustment ratios decrease with time, indicating the need to adjust the more recent discharges that correspond to greater urbanization in the watershed.

The behavior of the adjustment equation can be observed clearly by comparing years 1973 and 1999 (table 1). In 1973, the peak discharge was 3,020 ft $3 / \mathrm{s}$, and imperviousness was about 5.6 percent. The adjusted discharge for 1973 is $2,397 \mathrm{ft}^{3} / \mathrm{s}$. In comparison, the peak discharge in 1999 was 3,060 ft³/s, and imperviousness was 12.8 percent. The adjusted discharge for 1999 is $2,144 \mathrm{ft}^{3} / \mathrm{s}$. Although the observed discharge in 1999 is only slightly greater $\left(40 \mathrm{ft}^{3} / \mathrm{s}\right)$ than the observed discharge in 1973 , the adjusted discharge for 1973 is greater by $253 \mathrm{ft}^{3} / \mathrm{s}$ than the adjusted discharge for 1999 . This clearly indicates the role of the annual imperviousness time series in this study. It is worth noting that imperviousness in the watershed between 1970 and 2000 increased from 4.8 percent to almost 13 percent, which represents more than a doubling of impervious area. For this reason, USGS streamgage 01645000 would have been eliminated from the Sauer and others (1983) study because their threshold of a 50-percent increase in imperviousness.

Finally, it is instructive to look at the 5-year flood-frequency values and compare these to the 5-year rural regression equation value of $5,876 \mathrm{ft}^{3} / \mathrm{s}$ determined from Dillow (1996). While the observed 5-year peak discharge is 1.27 times the rural regression estimate, the adjusted 5-year peak is only 1.05 times this estimate. The similarity of the adjusted 5-year peak to the rural regression estimate is indicative of the success of the calibrated adjustment equation in quantifying the effect of imperviousness on the annual maximum discharge. 
Table 1. Example of the adjustment of the observed annual maximum time series using the 5-year simple imperviousness adjustment model for U.S. Geological Survey streamgage 01645000, Seneca Creek at Dawson, Maryland.

\begin{tabular}{|c|c|c|c|c|}
\hline Year & $\begin{array}{c}\text { Imperviousness } \\
(\%)\end{array}$ & $\begin{array}{c}\text { Observed } \\
Q\left(\mathbf{f t}^{3} / \mathbf{s}\right) \\
\end{array}$ & $\begin{array}{c}\text { Adjusted } \\
Q\left(\mathbf{f t}^{3} / \mathbf{s}\right) \\
\end{array}$ & $\begin{array}{l}Q_{\text {adji, }}(t) \\
I Q_{\text {obs }}(t)\end{array}$ \\
\hline 1970 & 4.84 & 2,200 & 1,702 & 0.774 \\
\hline 1971 & 5.10 & 25,900 & 28,787 & 1.111 \\
\hline 1972 & 5.37 & 26,100 & 28,831 & 1.105 \\
\hline 1973 & 5.63 & 3,020 & 2,397 & 0.794 \\
\hline 1974 & 5.90 & 3,160 & 2,508 & 0.794 \\
\hline 1975 & 6.16 & 16,000 & 16,094 & 1.006 \\
\hline 1976 & 6.42 & 4,900 & 4,101 & 0.837 \\
\hline 1977 & 6.69 & 3,770 & 3,016 & 0.800 \\
\hline 1978 & 6.95 & 7,850 & 6,969 & 0.888 \\
\hline 1979 & 7.22 & 16,000 & 15,716 & 0.982 \\
\hline 1980 & 7.48 & 10,800 & 9,946 & 0.921 \\
\hline 1981 & 7.85 & 1,340 & 896 & 0.668 \\
\hline 1982 & 8.23 & 3,160 & 2,385 & 0.755 \\
\hline 1983 & 8.60 & 3,260 & 2,455 & 0.753 \\
\hline 1984 & 8.98 & 3,010 & 2,225 & 0.739 \\
\hline 1985 & 9.35 & 3,620 & 2,734 & 0.755 \\
\hline 1986 & 9.73 & 1,070 & 669 & 0.625 \\
\hline 1987 & 10.10 & 4,950 & 3,871 & 0.782 \\
\hline 1988 & 10.48 & 7,410 & 6,120 & 0.826 \\
\hline 1989 & 10.85 & 8,250 & 6,886 & 0.835 \\
\hline 1990 & 11.23 & 2,270 & 1,553 & 0.684 \\
\hline 1991 & 11.40 & 5,120 & 3,947 & 0.771 \\
\hline 1992 & 11.58 & 1,750 & 1,146 & 0.655 \\
\hline 1993 & 11.76 & 3,350 & 2,412 & 0.720 \\
\hline 1994 & 11.93 & 9,160 & 7,651 & 0.835 \\
\hline 1995 & 12.11 & 2,080 & 1,388 & 0.667 \\
\hline 1996 & 12.28 & 11,000 & 9,399 & 0.854 \\
\hline 1997 & 12.46 & 3,880 & 2,829 & 0.729 \\
\hline 1998 & 12.64 & 5,280 & 4,023 & 0.762 \\
\hline 1999 & 12.81 & 3,060 & 2,144 & 0.701 \\
\hline 2000 & 12.99 & 1,910 & 1,244 & 0.651 \\
\hline$Q_{5}$ & & 7,435 & 6,157 & \\
\hline
\end{tabular}




\section{Methods}

The database used for this investigation contains watershed characteristics for 78 USGS streamgages across the United States (Appendix 1). The two most critical elements in this database are the flood-frequency values obtained directly from the gage record and the flood-frequency values obtained from the current USGS rural discharge equations that apply at each gage site. In this section, the method for determining these two sets of values for the gages used in this investigation is discussed. Other ancillary data, such as outlier values, development of impervious-cover time series from census data, and determination of watershed characteristics also are discussed.

\section{Development of Rural Peak Discharge Estimates}

The premise of the current study is that the USGS rural flood-frequency regression equations for each State represent the best estimate of the nonurbanized flood-frequency at any gage analyzed in the study. Thus, it is necessary to apply these equations to each gage included in the study and use the flood-frequency results in the development of the urban adjustment methods.

\section{Delineation of Watershed Boundaries}

For each gage used in the study, the digital elevation model (DEM) covering the extent of the gaged watershed was obtained from the National Elevation Dataset (NED; U.S. Geological Survey, 2004a). Flow directions were constrained by "burning in" stream locations from the 1:100,000-scale National Hydrography Dataset (NHD; U.S. Geological Survey and U.S. Environmental Protection Agency, 2004). Standard GIS techniques were used to fill depressions and determine flow directions using a D8 algorithm (Jenson and Domingue, 1988). The watershed boundaries were delineated automatically by indicating the location of the streamgage to the GIS and initiating the delineation algorithm. An automated delineation is considered acceptable and consistent with USGS standards if the delineated drainage area is within 10 percent of the drainage area reported by the USGS (U.S. Geological Survey, 2004b).

\section{Estimation of Watershed Characteristics}

Using the watershed boundaries generated as described in the previous section other watershed characteristics were determined as needed from additional interpretation of the DEM (for example, calculating the channel slope). If additional landuse and land-cover descriptors were needed, such as percentage of forest cover, these data were determined by using the most current land-use and land-cover data available. In most cases this meant using the 1992 National Land Cover Dataset (NLCD; Vogelmann and others, 1998a, 1998b; U.S. Geological Survey, 2005), although the 2001 NLCD (Homer and others, 2004; Multi-Resolution Land Characterization Consortium, 2005) was available for some locations during this study.

\section{Development of Flood-frequency Estimates from Gage Record}

Flood-frequency estimates were developed from the observed annual maximum time series recorded as peak streamflow by the USGS (U.S. Geological Survey, 2004b). In this section, the methods will be discussed for selecting the gages used in the analysis, obtaining the observed annual maximum time, and using the PeakFQ program (Flynn and others, 2005) to analyze the data and produce the flood-frequency values.

\section{Selection of Gages}

The following list of criteria was used for selecting gages for this study:

- The gage must have been active for 20 or more years during 1970-2000, the first full period for which census population data are available in digital format.

- The gage must not be subject to flow regulation.

- The gage must be equipped to report measured peak discharges, not just stage measurements.

- The current peak-flow regression equations for the gage cannot be dependent on a measure of urbanization for flood prediction. 


\section{Methods for Adjusting USGS Rural Regression Peak Discharges in an Urban Setting}

- The drainage area for the gage, as determined by GIS, must be within plus or minus 10 percent of the reported USGS drainage area for the gage, thus providing a high degree of confidence in the application of GIS methods for determining the rural discharge estimates.

- The gage record must not have a large proportion (approximately 20 percent) of streamflow values identified as outliers by the PeakFQ program.

- The gage drainage area should contain more than 5 percent impervious area as quantified by the NLCD 2001 (MultiResolution Land Characteristics Consortium, 2005).

Applying these criteria resulted in the final selection of 78 gages in 12 States for the study analyses. The States in which the gages are located are California, Florida, Illinois, Maryland, Massachusetts, Michigan, Mississippi, Nevada, New York, Rhode Island, Virginia, and West Virginia (fig. 1).

\section{Observed Annual Maximum Time Series}

The observed annual maximum time series was obtained from the USGS (U.S. Geological Survey, 2004b). Observed peak discharge values for each study gage were obtained for all recorded floods occurring between 1970 and 2000. Data were collected in WATSTORE format, which can be read directly by the PeakFQ program.

\section{Use of the PeakFO Program}

The USGS developed the PeakFQ computer program (Flynn and others, 2005) to conduct flood-frequency analyses based on the guidelines in Bulletin 17B (Interagency Advisory Committee on Water Data, 1982). The PeakFQ program uses the sample-moment method to fit the Pearson Type III frequency distribution to the logarithms of annual flood peaks. The skew that is used may be (a) user-developed generalized skew for a region, (b) the skew map from Bulletin 17B, (c) computed from the data, or (d) weighted between the generalized skew and station skew computed from the data. Adjustments can be made for high and low outliers and historic information. Qualification codes can be used to censor data from the analysis.

\section{Skew}

The PeakFQ program offers several options for defining a skew value to use in developing a flood-frequency estimate. In developing rural flood-frequency estimates for a given State, a regionalized skew typically is developed that is weighted with the local skew at the gaging station being analyzed. For urban estimates, this method is problematic because of fewer urban watersheds from which to develop a regionalized value and the varying extent of urbanization. In this study, therefore, each gaging station was considered individually and the "station skew" option was used throughout the analyses presented in this report.

\section{PeakF0 Run-Time Parameters}

Because of the relatively short periods of record (31 years or less) for the flood-frequency analysis, there is a greater possibility of time-sampling errors than may be expected when examining longer periods of record. To reduce the potential effects of these errors, a systematic method for applying the high-outlier option of the PeakFQ program was applied. To apply this option, however, two quantities must be defined - the discharge threshold that defines the minimum high-outlier discharge and the return frequency of the largest discharge in the systematic record analyzed. Because of the nature of the model calibration process, the procedures outlined here were performed repeatedly (for each iteration, for each gage, for each return period examined) in calibrating various trial-adjustment models.

\section{Identifying the High-Outlier Threshold}

The high-outlier threshold is the largest discharge that is considered within the normal range of discharge for a particular time series being analyzed. Discharges greater than this threshold were not attributed a probability using the Weibull plotting position formula in the analyses. The high-outlier discharge threshold was determined by the following method: given an annual maximum time series of $n$ discharges at a particular gage, it was arbitrarily decided that these $n$ values would represent the flood-frequency characteristics for that location for a period four times as long. Although this is an arbitrary assumption, it adequately produced the desired effect of filtering out large extreme floods that far exceeded the periods of record being analyzed while allowing the consideration of moderate-sized floods. Thus, the approach for identifying outlier discharges for this study is not consistent with the approach outlined in Bulletin 17B; however, this outlier-identification approach was a repeatable criterion that worked effectively and could be applied uniformly. 
The discharges determined from the rural flood-frequency regression equations were used to determine the high-outlier threshold. The flood-frequency distribution was treated as a piecewise log-normal distribution, and the high-outlier threshold was determined by linear interpolation within the bounds of these values by applying the following equation:

$$
\log \left(Q_{o}\right)=\left[\frac{\log \left(Q_{u}\right)-\log \left(Q_{l}\right)}{\log \left\{z\left(T_{u}\right)\right\}-\log \left\{z\left(T_{l}\right)\right\}}\right]\left[\log \{z(4 n)\}-\log \left\{z\left(T_{l}\right)\right\}\right]+\log \left(Q_{l}\right),
$$

where $T_{l}<4 n \leq T_{u}$ and $z\left(T_{x}\right)$ is the standard normal deviate corresponding to a flood of return period, $T_{x}$. Thus, the high-outlier threshold $\left(Q_{o}\right)$, is determined simply as

$$
Q_{o}=10^{\log \left(Q_{o}\right)} .
$$

\section{Identifying the Historic Period for the Largest Flood in the Time Series}

In a similar manner, the largest flood in the systematic record was assigned a value for the historic period that it represents given the rural regression flood-frequency equation estimates that apply to a specific watershed. The largest flood was compared to the rural flood-frequency distribution, and a return period was determined by interpolating from this distribution, thus treating the flood-frequency distribution as a piecewise log-normal distribution. If the largest flood in the systematic record exceeded the 500-year rural flood, a return period of 500 years was arbitrarily assigned to the flood. The interpolation was performed as follows:

$$
z\left(Q_{o}\right)=\left[\frac{\log \left(Q_{o}\right)-\log \left(Q_{l}\right)}{\log \left(Q_{u}\right)-\log \left(Q_{l}\right)}\right]\left[z\left(Q_{u}\right)-z\left(Q_{l}\right)\right]+z\left(Q_{l}\right),
$$

where $Q_{l}<Q_{o} \leq Q_{u}$ and $z\left(Q_{x}\right)$ is the standard normal deviate corresponding to a flood of magnitude, $Q_{x}$. With $z\left(Q_{o}\right)$ known, the cumulative probability $\left(P\left(Q_{o}\right)\right)$ associated with this value was determined from the standard normal distribution. Finally, the return period $\left(T\left(Q_{o}\right)\right)$ was determined by using

$$
T\left(Q_{o}\right)=\frac{1}{1-P\left(Q_{o}\right)} .
$$

\section{Example Application of Outlier and Historical Period Identification Procedures}

To illustrate the application of the outlier and historical period identification procedures, the procedures were applied to the record of USGS streamgage 02037800, Falling Creek near Midlothian, Virginia. The period of record for this gage is 19512003, with several breaks in the record. Because of limited census data, only the period 1970-2000 was considered. Further, the gage was inactive in 1978 and again from 1994 to 2000; therefore, only the records for the periods 1970-1977 and 1979-1993 were available for this study. The largest flood during these two periods had a magnitude of 5,170 ft $3 / \mathrm{s}$ and occurred in 1979 . The next largest flood had a magnitude of 1,400 ft 33 s and occurred in 1985 (fig. 4).

The rural peak discharges determined from Bisese (1995) for the Southern Piedmont region produced peak-discharge estimates for the streamgage at Falling Creek of $380 \mathrm{ft}^{3} / \mathrm{s}, 647 \mathrm{ft}^{3} / \mathrm{s}, 862 \mathrm{ft}^{3} / \mathrm{s}, 1,217 \mathrm{ft}^{3} / \mathrm{s}, 1,552 \mathrm{ft}^{3} / \mathrm{s}, 1,923 \mathrm{ft}^{3} / \mathrm{s}$, and $3,054 \mathrm{ft}^{3} / \mathrm{s}$ for the 2-, 5-, 10-, 25-, 50-, 100-, and 500-year floods, respectively. To identify the high-outlier threshold $\left(Q_{m}\right)$ and determine the return period corresponding to the largest flood, the following criteria were applied. The length of the time series used in the analysis was $n=23$ years, representing the 1970-1977 and 1979-1993 periods of record. Using $4 n=92$ years, the log-normally interpolated 92-year flood from equations 21 and 22 is $1,876 \mathrm{ft}^{3} / \mathrm{s}$. No interpolation is necessary to determine the return period corresponding to the largest flood for either the observed or adjusted (discussed later) annual maximum time series because the observed $\left(5,170 \mathrm{ft}^{3} / \mathrm{s}\right)$ and adjusted $\left(4,220 \mathrm{ft}^{3} / \mathrm{s}\right)$ values exceed the rural 500-year flood of 3,054 $\mathrm{ft}^{3} / \mathrm{s}$. A 500-year return period is arbitrarily attached to the largest flood during the periods of record analyzed. Thus, the PeakFQ program was executed for both the observed and adjusted annual maximum time series using station skew, high-outlier threshold $\left(1,876 \mathrm{ft}^{3} / \mathrm{s}\right)$, and historical period (500 years). 


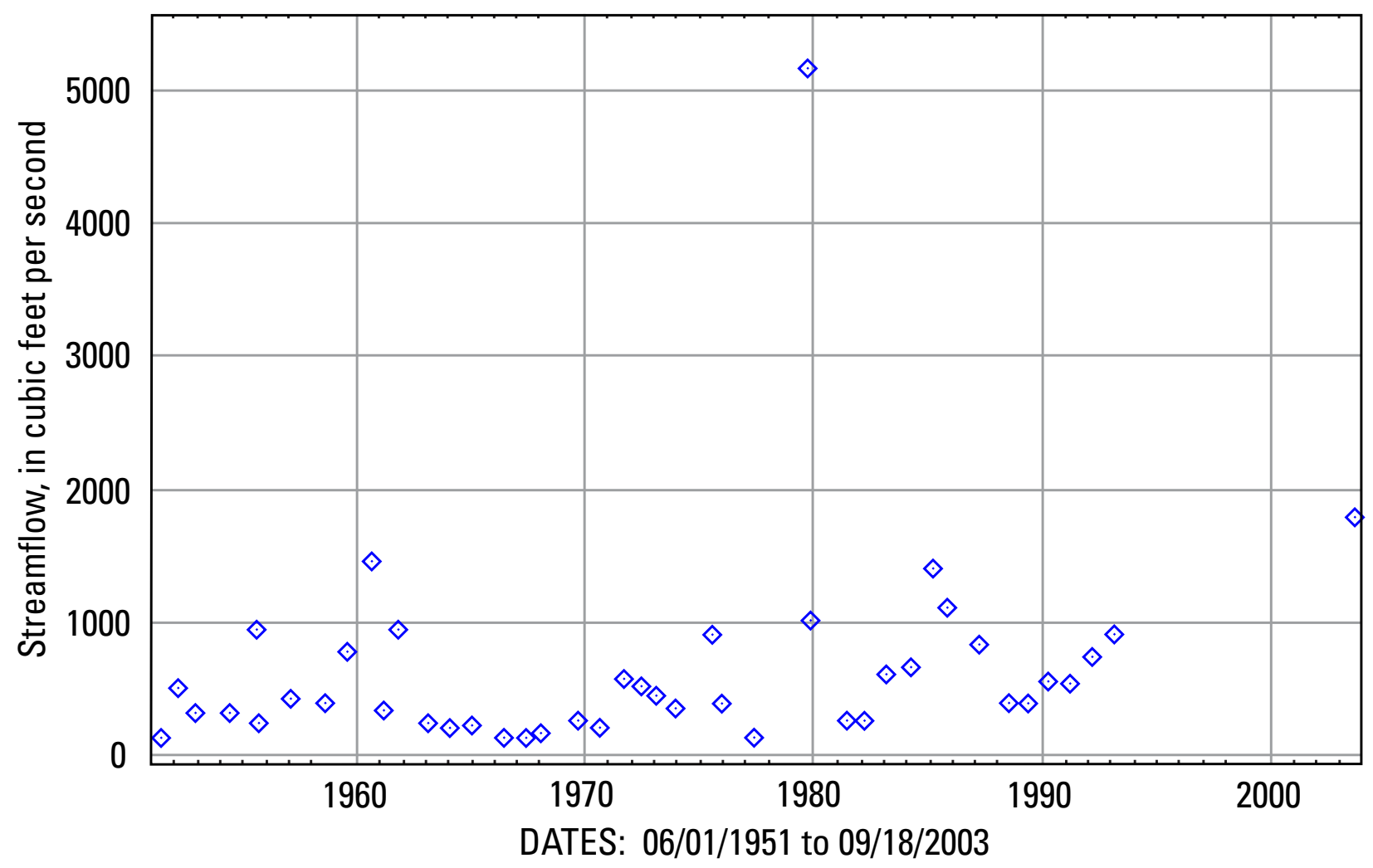

Figure 4. Annual maximum time series for U.S. Geological Survey streamgage 02037800, Falling Creek near Midlothian, Virginia.

\section{Land-Use Change Time Series}

This study draws heavily on the idea of developing a time series of changes in the spatial characteristics of the landscape. As a single descriptor of land-use change, imperviousness is the most simple characteristic that can be identified as having a strong influence on flood magnitude. Historical records of imperviousness are scarce, however, in both the spatial and temporal dimensions. For this reason, historical census-derived population-density estimates were used as a surrogate of imperviousness and as a predictor of imperviousness from which to develop the necessary space-time estimates of the changing landscape.

\section{Population Density}

Census data are readily available in 10-year increments and digital format for 1970 through 2000. Assuming linear changes in population density between incremental census data, it is possible to develop space-time estimates of population density for any location in the United States at the resolution of a census tract. Census tracts vary considerably in scale depending on population density. For this study, the focus was on urban areas for which the census data tend to delineate small-scale census tracts. For example, Montgomery County, Maryland, is a densely populated county directly north of Washington, D.C. In the 2000 census, this county was composed of 177 census tracts (GeoLytics, 2003), ranging in size from $0.13 \mathrm{mi}^{2}$ to $70 \mathrm{mi}^{2}$ and averaging $2.86 \mathrm{mi}^{2}$. Population density is not uniformly distributed among these tracts, however, and smaller tracts tend to have greater population densities, as shown in figure 5.

Landscape changes, such as increases in imperviousness, introduction of curb and gutter drainage, and channelization can vary with population density. Using a single, average population-density value and the landscape changes for which it is a surrogate to quantify human influences within a watershed may be a poor model when a watershed is large or if human influences vary considerably. To quantify such variability or nonhomogeneity within a watershed, the distribution of population densities was quantified as a fraction of the total watershed area as shown in the example for USGS streamgage 01645000, Seneca Creek at Dawsonville, Maryland (fig. 6). The population densities that correspond to the $10^{\text {th }}$ and $90^{\text {th }}$ percentiles of the watershed area were tagged, and the difference between these densities was recorded. This quantity $(\triangle P D)$ was defined as follows:

$$
\triangle P D=P D_{10}-P D_{90}
$$




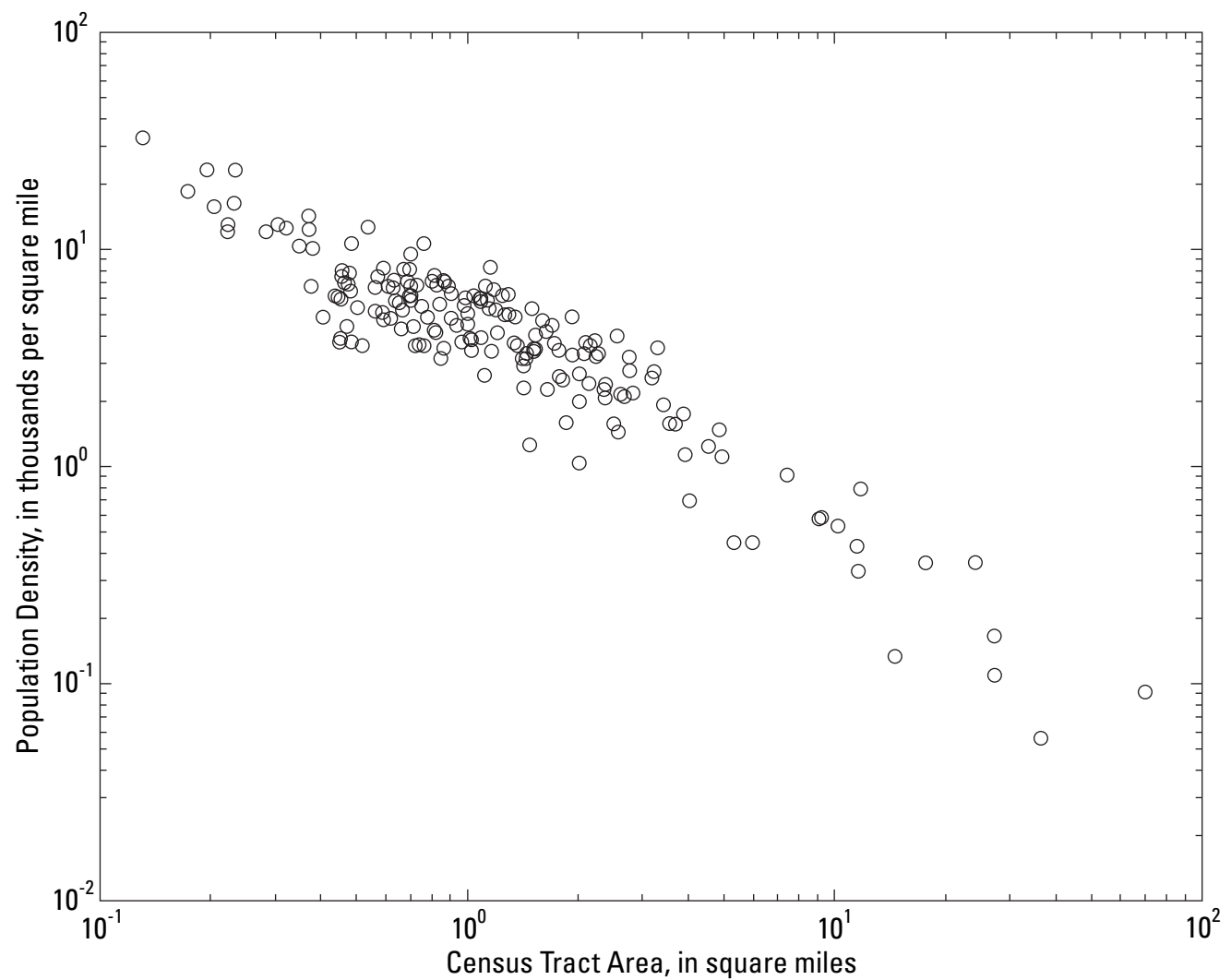

Figure 5. Population density in Montgomery County, Maryland, as a function of census tract area from the 2000 census.

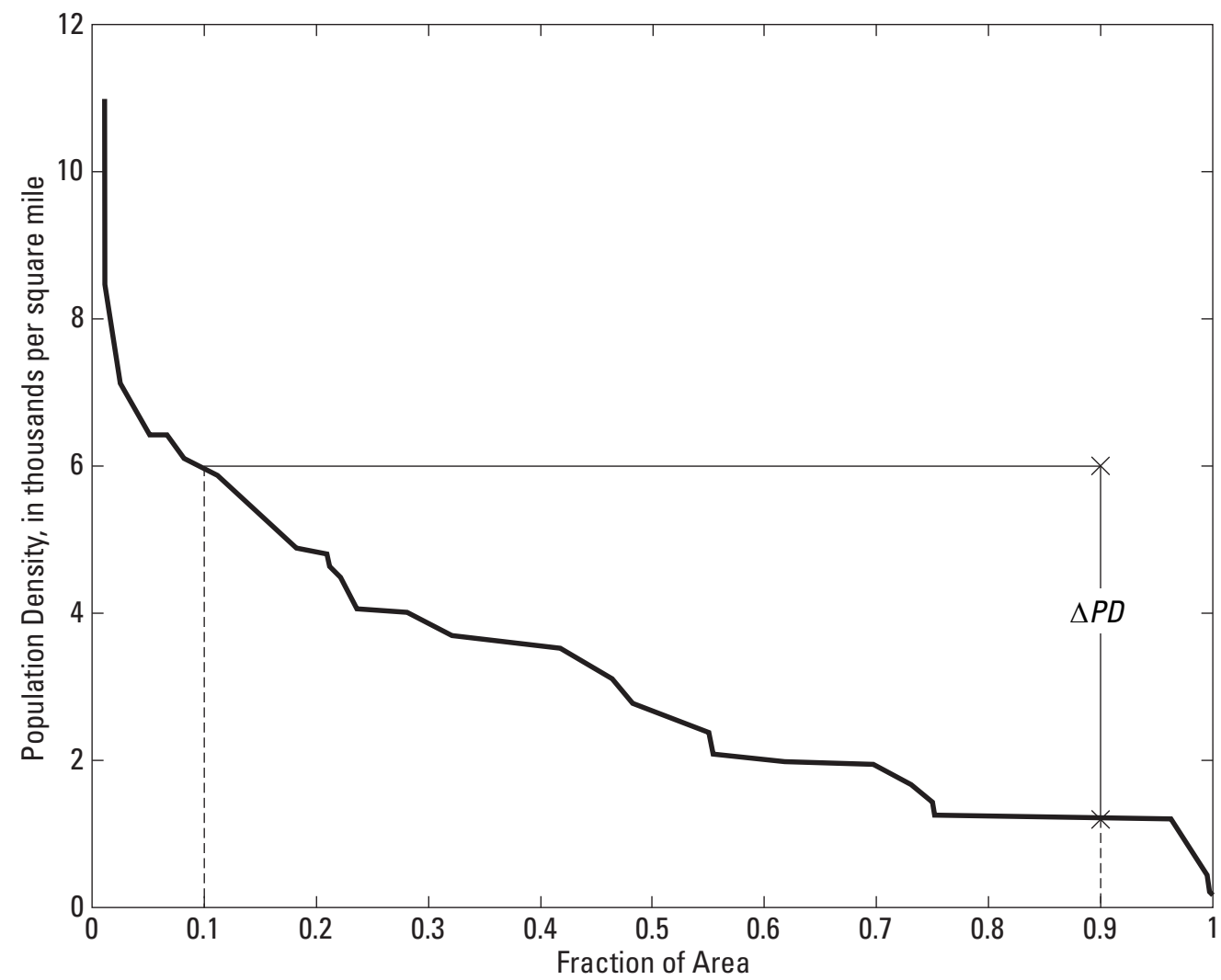

Figure 6. Distribution of population density as a fraction of the total watershed area for U.S. Geological Survey streamgage 01645000, Seneca Creek at Dawsonville, Maryland. $\left[\triangle P D\right.$ is the difference in population density between the $10^{\text {th }}$ and $90^{\text {th }}$ percentiles of the distribution of population density in the watershed.] 
The more homogeneous the distribution of population within a watershed, the smaller $\triangle P D$ will be. $\triangle P D$ is a potentially useful predictor, as discussed in the earlier section on Adjustment Models.

\section{Imperviousness}

The 2001 NLCD includes imperviousness mapping product at 30-meter resolution. Each pixel reports a value of imperviousness as a percentage of the total area of the pixel. The determination of the percentage of imperviousness across an entire watershed is straightforward and requires simply calculating the average imperviousness from the set of pixels within the watershed.

\section{Estimating Imperviousness from Census Data}

A time series of historical land-use (or imperviousness) data covering several decades and uniformly available at the national scale does not exist. Because of the need to develop estimates of imperviousness for each year for each watershed being studied, it was necessary to develop a procedure that could be uniformly applied to each watershed.

The imperviousness layer from the 2001 NLCD was obtained for the central region of Maryland because it was available and because this region includes two highly urbanized areas-Baltimore, Maryland, and Washington, D.C. Similarly, tract data from the 2000 census were obtained. For each census tract, the population density (in thousands of people per square mile) was determined based on the reported total population and the area of the tract as determined by using GIS. Similarly, the tract outlines were used to sample the 2001 NLCD imperviousness layer and to determine the average imperviousness for each tract. Several different models were investigated for describing the relation between population density and imperviousness. A simple power model was selected to provide the best compromise between statistical power and model rationality. The calibrated equation took the following form:

$$
I A=12.1953(P D)^{0.5195}
$$

where $I A \quad$ is imperviousness, in percent; and

$P D \quad$ is population density in thousands of people per square mile.

This equation was determined for $0.0002<P D<176.4$ and $0.08<I A<96.66$. The median $P D$ and $I A$ values were 3.87 and 21.8, respectively. The regression was performed using data from 998 census tracts. The ratio of the standard error $\left(S_{e}\right)$ of equation 26 to the standard deviation $\left(S_{d}\right)$ of observed imperviousness was $S_{e} / S_{d}=0.6163$, with an explained variance of 62.1 percent.

The regression equation developed by Stankowski (1972) to estimate imperviousness from population density in New Jersey had a different form from that of equation 26 :

$$
I A=0.117 P D^{0.792-0.039 \log P D},
$$

where $I A \quad$ is imperviousness, in percent; and

$P D$ is populatin density, in persons (not thousands of persons) per square mile.

The results of both equations, however, are quite comparable, as shown in figure 7.

In focusing on predicted imperviousness between 0 and 50 percent, which is the typical range observed in most watersheds, the maximum departure between the two methods is about 1.2 percent (fig. 7). The estimated imperviousness obtained by using equation 27 is 31.0 percent and 29.8 percent by using equation 26 for a population density of approximately 5,660 persons per square mile. While the difference is small, it is even less significant considering that most of the watersheds in this study had lower population densities and, thus, smaller estimated imperviousness. The typical departure in estimates of imperviousness between the two methods for the watersheds included in this study was less than 1.0 percent.

\section{Implementation of Historical Census Data}

Historical census tract data were obtained for 1970, 1980, 1990, and 2000. Population density and estimated imperviousness were determined, using equation 26 , for each census tract in each study watershed for each census period. The watershed boundary was then used to select all intersecting census tracts, and an area-weighted average of imperviousness for each census period was determined for each watershed. Imperviousness was assumed to vary linearly between each census measure. 


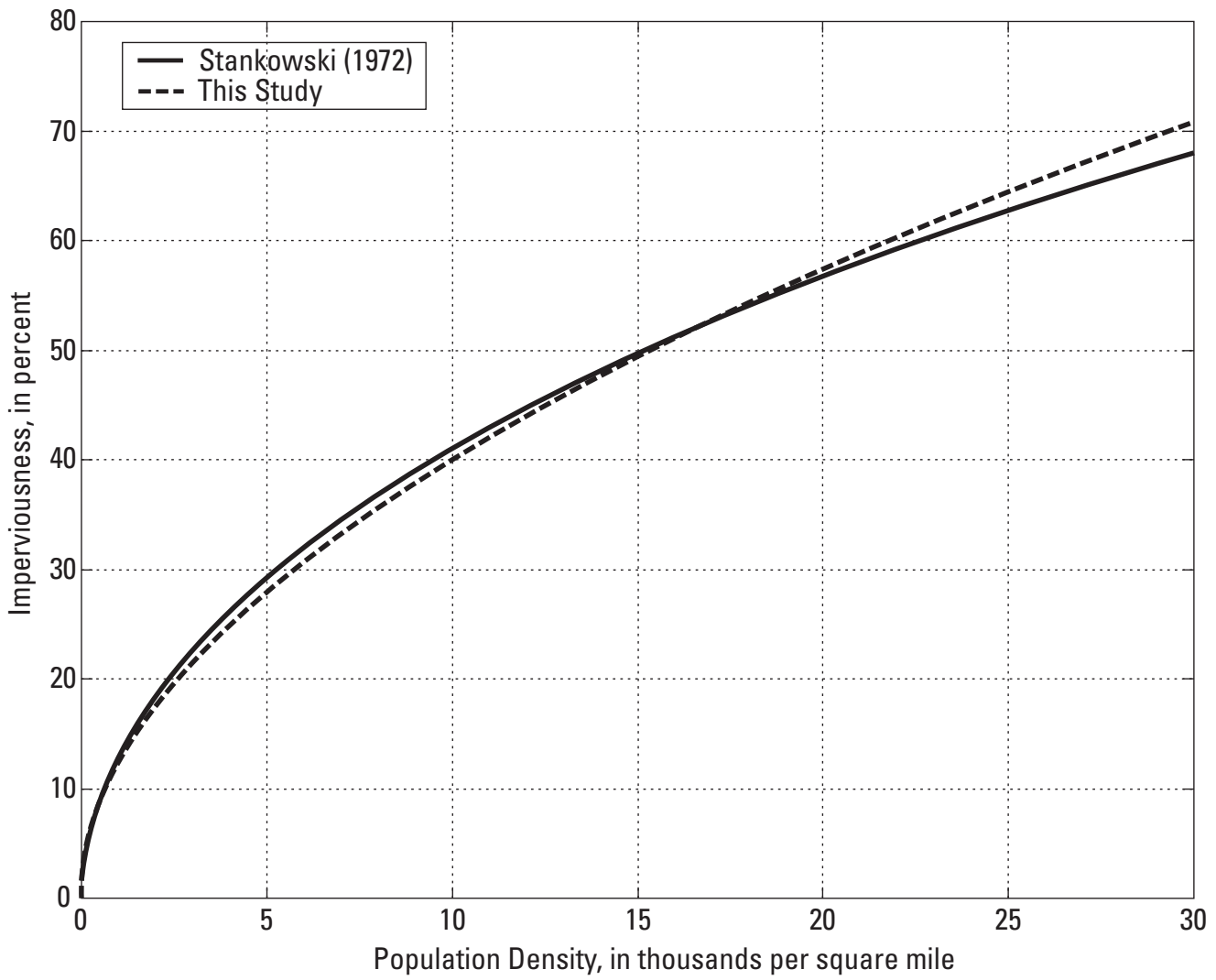

Figure 7. Relations of imperviousness to population density as measured by Stankowski (1972) and as measured in this study. [Note: Stankowski's (1972) equation was based on density in persons per square mile while this study's equation was based on density in thousands of persons per square mile. For consistency in this figure, Stankowski's (1972) equation was revised to be based on thousands of persons per square mile.]

In the event of decreasing population density over time, the estimate of imperviousness naturally would decline (eq. 26). Although population could decrease, imperviousness was assumed to be a strictly nondecreasing function with time and, therefore, was assumed to remain at the previous value. Of the 78 watersheds studied, 10 had decreasing population estimates and nonvarying estimates of imperviousness during the entire gaged period.

To illustrate the use of historical census data in estimating imperviousness, census tract data were obtained for the watershed of USGS streamgage 01645000, Seneca Creek at Dawsonville, Maryland (fig. 8). Equation 26 was applied to population densities for 1970, 1980, 1990, and 2000. The resulting imperviousness estimations for these years were 4.84 percent, 7.48 percent, 11.23 percent, and 12.99 percent, respectively.
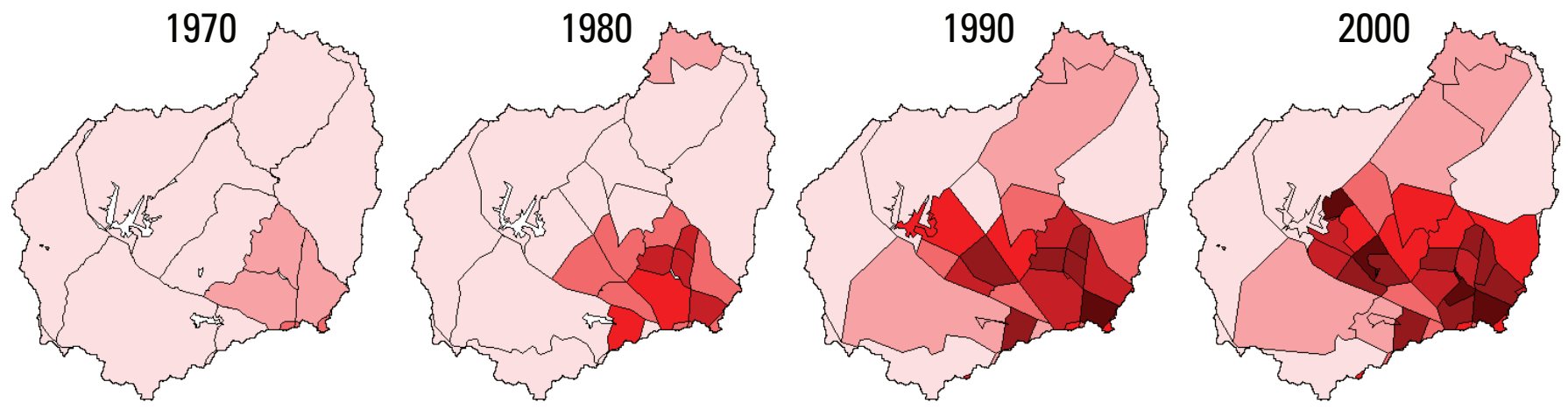

Figure 8. Estimated imperviousness from census tract data for U.S. Geological Survey streamgage 01645000, Seneca Creek at Dawsonville, Maryland. [Imperviousness in this figure ranges from $\mathbf{0}$ to $\mathbf{4 0}$ percent. Darker shades correspond to high degrees of imperviousness.] 


\section{Results}

Previously, in the "Methods" section the need to censor gages with non-elevated flood-frequency was discussed. The actual numbers of streamgages that were used in the calibration of the adjustment equations as a function of the flood-frequencies being considered are given in table 2 .

Table 2. Number of gages used in the regression analysis as a function of return period.

\begin{tabular}{lccccccc}
\hline $\begin{array}{c}\text { Return period } \\
\text { (years) }\end{array}$ & $\mathbf{2}$ & $\mathbf{5}$ & $\mathbf{1 0}$ & $\mathbf{2 5}$ & $\mathbf{5 0}$ & $\mathbf{1 0 0}$ & $\mathbf{5 0 0}$ \\
\hline $\begin{array}{l}\text { Number of } \\
\text { streamgages } \\
\text { used }\end{array}$ & 52 & 52 & 50 & 48 & 43 & 41 & 28 \\
\hline
\end{tabular}

In total, information was obtained from 61 of the 78 streamgages (identified by italics in appendix 2) for at least one of the seven frequencies for which urban regression equations were calibrated in this study. In other words, of the 78 streamgages originally selected for use in this study, observed flood-frequency estimates for 17 of the streamgages were no greater than the rural regression estimates for any of the seven frequencies examined. The explanation for this is attributed collectively to error inherent in the rural regression equations, possible error in the discharge measurement or corresponding rating curve, error in the flood-frequency analysis, and other inherent characteristics (such as manmade storage or missing basin attributes) that may have served to reduce the flood magnitudes as predicted by the rural regression equations.

The goodness-of-fit characteristics for the model calibrations are presented in table 3, and the calibrated coefficients are shown in table 4 . Table 3 presents standard error $\left(S_{e}\right)$ calculated as

$$
S_{e}=\sqrt{\frac{1}{n-m} \sum(y-\hat{y})^{2}},
$$

where $n \quad$ is the number of observations,

$m \quad$ is the number of coefficients or exponents being calibrated,

$y \quad$ is the observed discharge (from the PeakFQ output), and

$\hat{y} \quad$ is the predicted output calibrated by the nonlinear regression tool.

Standard deviation $\left(S_{y}\right)$ is calculated as

$$
S_{y}=\sqrt{\frac{1}{n-1} \sum(y-\bar{y})^{2}},
$$

where $\bar{y} \quad$ is the mean of the discharges for the return period $(T)$.

Explained variance $\left(R^{2}\right)$ is calculated as

$$
R^{2}=\frac{1}{n^{2} \cdot S_{e}^{2} \cdot S_{x}^{2}}\left[\sum(y-\hat{y}) \cdot(y-\bar{y})\right]^{2},
$$

where

$$
S_{x}=\sqrt{\frac{1}{n-1} \sum(\hat{y}-\overline{\hat{y}})^{2}}
$$

in which $\overline{\hat{y}}$ is the mean of the predicted discharges for the return period $(T)$.

As shown in table 3, the null model performed almost as well as the more sophisticated models, especially in regard to the standard error ratio measure. It must be noted, however, that only urban streamgages were used in this study. In particular, 
the calibrated equations were developed only for urban gages where the observed flood-frequency was associated with greater discharges than those predicted by the rural regression equations. Given such a dataset from which to calibrate an equation, the null model was certain to perform well simply because the data were already screened for the tendency to produce elevated flood magnitudes. The null model could be expected to have a poorer performance if both rural and urban streamgages were in the dataset. Further, the major shortcoming of the null model is that it will not predict larger urban discharges in relation to larger amounts of urbanization (imperviousness or density). The value of the null model is to provide some information about the additional predictive power of the models that include imperviousness in the flow-adjustment scheme.

Provided that a model that accounts quantitatively for urbanization is needed, the question now turns to which model of those examined performs "best." An absolute best model is not indicated in table 3 because only seven models were examined, and it is impossible to prove logically that the very best mathematical form was investigated. Nevertheless, the models examined encompass several different approaches to adjusting flows, and their performance probably is not far removed from the hypothetical best adjustment model. Further, the relative performance of the seven models varied, depending on the measure (explained variance or relative standard error) and the flood-frequency being considered (table 3). The goodness-of-fit values in table 3 were ranked within each measure and return period and the best performing model received a ranking of "1" with subsequent rankings increasing as model performance decreased (table 5). The rankings then were summed across both the explanatory measures and flood-frequencies, and the model producing the overall smallest sum was considered to be the best overall model among those considered. These summed rankings are presented in table 6 .

This ranking scheme indicates that the best overall performing model was the imperviousness distribution model (table 6). This assertion can be confirmed by a closer examination of table 3 in which the imperviousness distribution model produced the largest explained variance in three of the seven flood-frequencies examined and was among the top three performing models in this measure. With respect to relative standard error, the imperviousness distribution model is the best model in two of the seven flood-frequencies and was always among the top three performing models in this measure. In ranking overall performance, the imperviousness distribution model performed the best (slightly better than the density distribution model) with regard to explained variance and relative standard error (table 5).

In regard to the remaining models, one could ask two questions. First, does population density serve as a stronger predictor than imperviousness? Second, does the "simple" approach, such as simple imperviousness or simple density, outperform the "distribution" or "scaled" approach?

With regard to the first question, the tabulated results (table 5) indicate a modest advantage for imperviousness over density as a predictor. The imperviousness distribution model ranked first overall, whereas the density distribution model ranked second. The simple imperviousness model ranked fourth overall, whereas the simple density model ranked fifth. The oppo-

Table 3. Goodness-of-fit characteristics for the models evaluated.

[All statistics presented are for log-transformed discharges: $\log _{10}(Q)$. Bold values are best values for the return period.]

\begin{tabular}{|c|c|c|c|c|c|c|c|c|c|c|c|c|c|c|}
\hline \multirow{3}{*}{ Model } & \multicolumn{7}{|c|}{ Explained variance $\left(R^{2}\right)$} & \multicolumn{7}{|c|}{ Standard error ratio $\left(S_{\mathrm{e}} / S_{\mathrm{y}}\right)$} \\
\hline & \multicolumn{7}{|c|}{ Return period (years) } & \multicolumn{7}{|c|}{ Return period (years) } \\
\hline & 2 & 5 & 10 & 25 & 50 & 100 & 500 & 2 & 5 & 10 & 25 & 50 & 100 & 500 \\
\hline Null & 0.821 & 0.859 & 0.864 & 0.902 & 0.899 & 0.889 & 0.814 & 0.390 & 0.378 & 0.341 & 0.265 & 0.261 & 0.277 & 0.446 \\
\hline $\begin{array}{l}\text { Simple } \\
\text { imperviousness }\end{array}$ & 0.818 & 0.866 & 0.879 & 0.909 & 0.902 & 0.884 & 0.801 & 0.392 & 0.389 & 0.348 & 0.281 & 0.277 & 0.310 & 0.480 \\
\hline Simple density & 0.818 & 0.866 & 0.877 & 0.907 & 0.897 & 0.881 & 0.804 & 0.397 & 0.363 & 0.328 & 0.257 & 0.298 & 0.311 & 0.478 \\
\hline $\begin{array}{l}\text { Imperviousness } \\
\text { distribution }\end{array}$ & 0.832 & 0.867 & 0.874 & 0.909 & 0.901 & 0.897 & 0.855 & 0.385 & 0.374 & 0.338 & 0.292 & 0.268 & 0.271 & 0.356 \\
\hline $\begin{array}{l}\text { Density } \\
\text { distribution }\end{array}$ & 0.833 & 0.870 & 0.874 & 0.902 & 0.893 & 0.889 & 0.779 & 0.383 & 0.368 & 0.335 & 0.278 & 0.289 & 0.297 & 0.526 \\
\hline $\begin{array}{l}\text { Scaled } \\
\text { imperviousness }\end{array}$ & 0.822 & 0.873 & 0.869 & 0.904 & 0.900 & 0.884 & 0.810 & 0.409 & 0.396 & 0.365 & 0.288 & 0.280 & 0.310 & 0.528 \\
\hline Scaled density & 0.823 & 0.861 & 0.873 & 0.904 & 0.900 & 0.887 & 0.821 & 0.409 & 0.414 & 0.361 & 0.289 & 0.287 & 0.307 & 0.464 \\
\hline
\end{tabular}


Table 4. Calibrated values of the adjustment model coefficients and exponents.

[Variables for all models are defined in equations 12-18.]

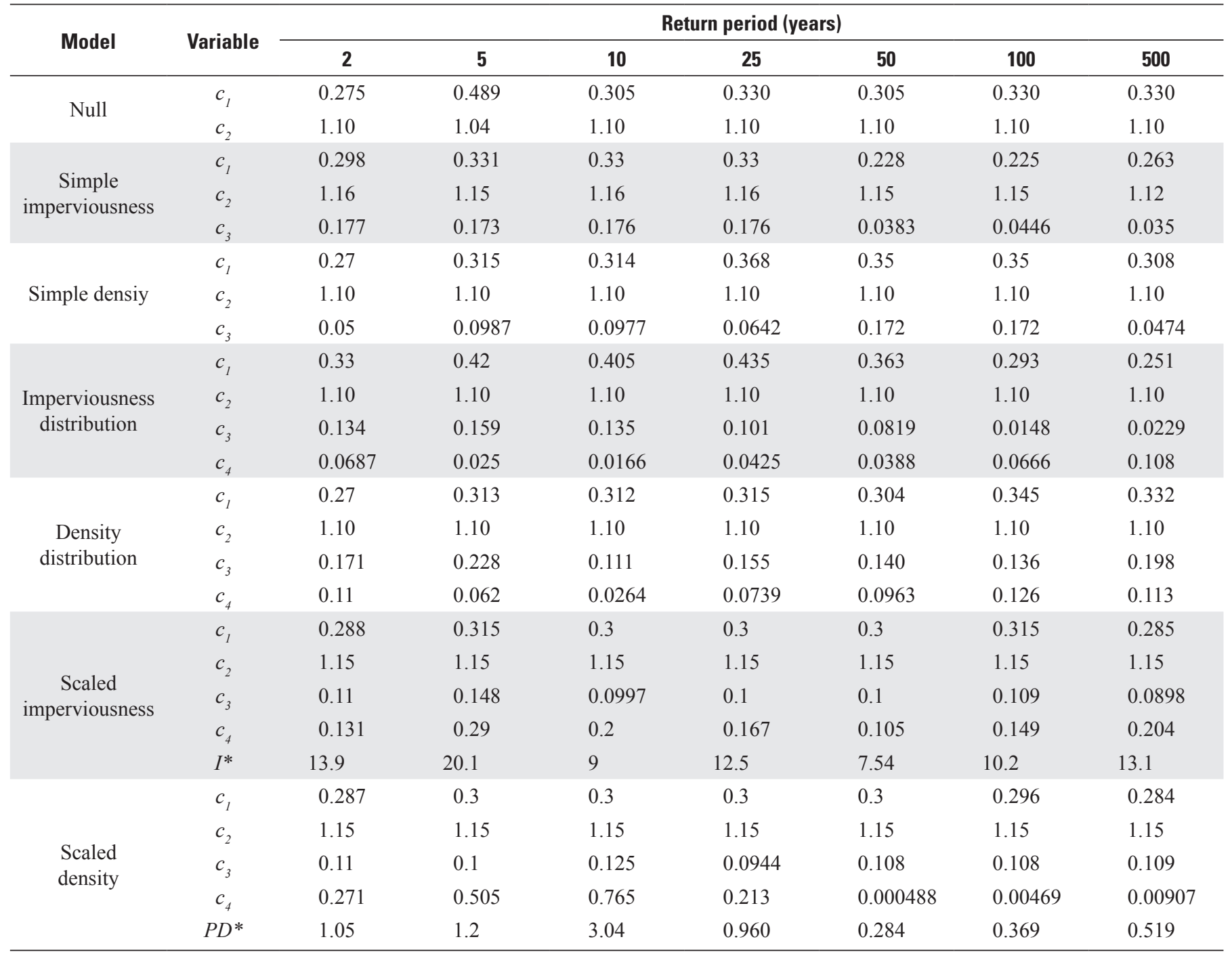


Table 5. Rankings of model performance based on the goodness-of-fit values shown in table 3.

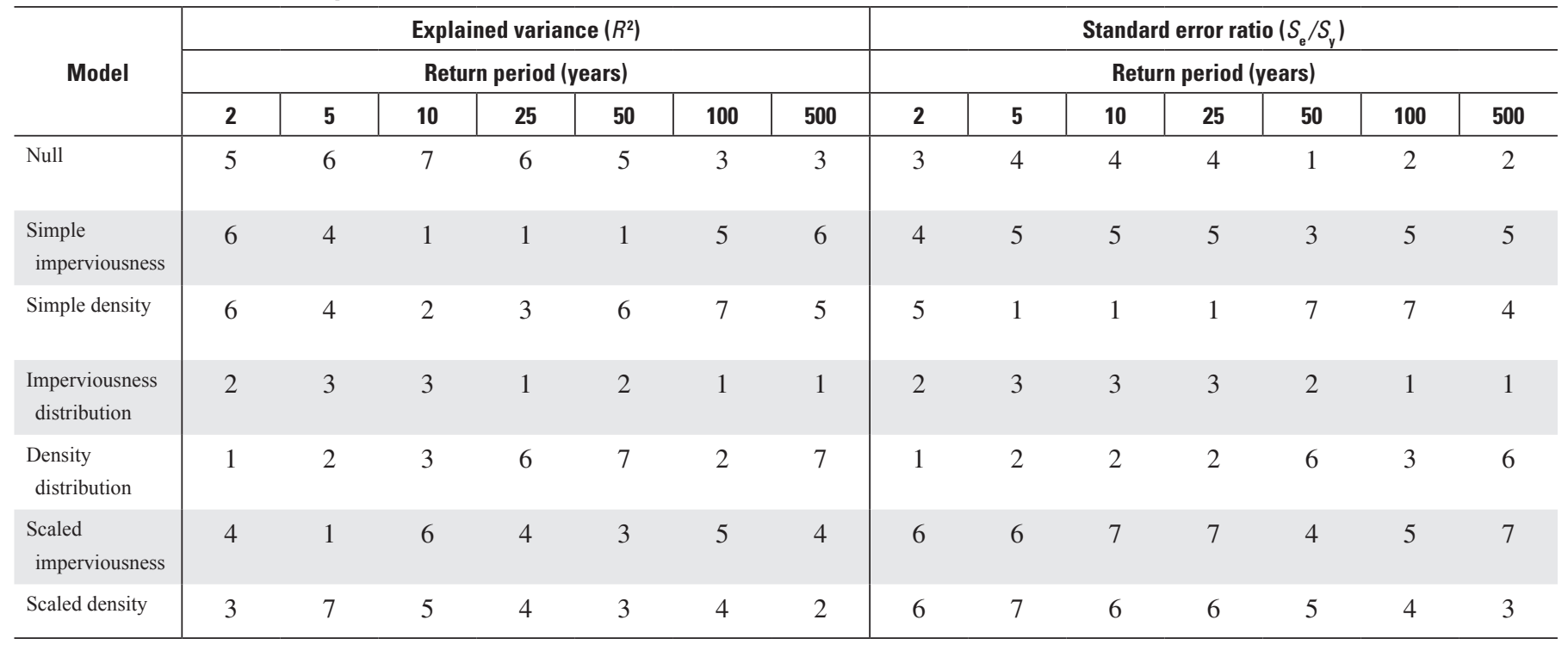

Table 6. Summed rankings of model calibration statistics based on goodness-of-fit values given in table 3.

[Bold values are best values for each column.]

\begin{tabular}{l|ccc}
\hline \multicolumn{1}{c|}{ Model } & $\begin{array}{c}\text { Explained variance, } \\
R^{2} \text { sum }\end{array}$ & $\begin{array}{c}\text { Standard error ratio, } \\
S_{\mathrm{e}} / S_{\mathrm{v}} \text { sum }\end{array}$ & $\begin{array}{c}\text { Overall sum } \\
\text { (Overall rank) }\end{array}$ \\
\hline Null & 35 & 20 & $55(3)$ \\
\hline $\begin{array}{l}\text { Simple } \\
\text { imperviousness }\end{array}$ & 24 & 32 & $56(4)$ \\
\hline $\begin{array}{l}\text { Simple density } \\
\begin{array}{l}\text { Imperviousness } \\
\text { distribution }\end{array}\end{array}$ & 33 & 26 & 59 (5) \\
\hline $\begin{array}{l}\text { Density } \\
\text { distribution }\end{array}$ & $\mathbf{1 3}$ & $\mathbf{1 5}$ & $\mathbf{2 8}(\mathbf{1})$ \\
\hline $\begin{array}{l}\text { Scaled } \\
\text { imperviousness }\end{array}$ & 28 & 22 & $50(2)$ \\
\hline \begin{tabular}{l} 
Scaled density \\
\hline
\end{tabular} & 27 & 42 & $69(7)$ \\
\hline
\end{tabular}


site trend occurred for the scaled models - the imperviousness-based model ranked seventh (last) and the density-based model ranked sixth. Thus, the results slightly favor imperviousness over population density as a predictor of flood-frequency magnitude.

With regard to the second question, the "distribution" approach (eqs. 15, 16) ranked first, followed by the "simple" approach (eqs. 13,14); the "scaled" models (eqs. 17, 18) performed the worst. This result is interesting because the simple models require the calibration of three parameters; the distribution models require four parameters, and the scaled models require five parameters. Generally, a more complex model would be expected to perform best because it has more flexibility to conform to the observed data. In this case, the moderately complex model performs best. The $\triangle P D$ or $\triangle I A$ term of the distribution model structure apparently is an effective way of quantifying urban heterogeneity within a watershed and, therefore, is useful in predicting flood behavior.

The calibration results for all models are presented in table 4. (Appendix 3 contains plots for comparing predicted and observed discharges for the calibrated simple imperviousness model, which is fairly representative of other model calibrations as well.) While the values shown in table 4 represent optimum calibration results, a brief examination of this table reveals somewhat erratic trends in many calibration parameters as return period varies. It would be expected that these parameters vary smoothly from one return period to the next. Towards this end, a secondary smoothing was performed for each calibration parameter using a linear regression model:

$$
\hat{c}_{x, T}=\alpha \log _{10}(T)+\beta,
$$

where $T$ is the return period and $\alpha$ and $\beta$ are determined by regressing the calibrated values of $c_{x, T}$ on $\log _{10}(T)$.

These smoothed parameter values were used in all subsequent analyses, because it was felt these values were more representative of the true relations between rural and urban flood magnitudes (table 7). Appendix 4 contains the calibrated and smoothed coefficients plotted against return periods for each adjustment model.

As stated previously, the functions, $f_{n}($.$) can be rearranged to express the urban peak discharge as a function of the rural$ peak discharge and imperviousness. For simplicity, the equation 11 can be revised as follows:

$$
f_{T}^{-1}=U Q_{T}
$$

Thus, the null model is rearranged as

$$
U Q_{T}=\left(\frac{1}{c_{1, T}}\right)^{\frac{1}{c_{2, T}}} R Q_{x}^{\frac{1}{c_{2, T}}}
$$

the simple imperviousness model is rearranged as

$$
U Q_{T}=\left(\frac{1}{c_{1, T}}\right)^{\frac{1}{c_{2, T}}} R Q_{T}^{\frac{1}{c_{2, T}}}(I A+1)^{\frac{c_{3, T}}{c_{2, T}}}
$$

the simple density model is rearranged as

$$
U Q_{T}=\left(\frac{1}{c_{1, T}}\right)^{\frac{1}{c_{2, T}}} R Q_{T}^{\frac{1}{c_{2, T}}}(P D+0.001)^{\frac{c_{3, T}}{c_{2, T}}}
$$

the imperviousness distribution model is rearranged as

$$
U Q_{T}=\left(\frac{1}{c_{1, T}}\right)^{\frac{1}{c_{2, T}}} R Q_{T}^{\frac{1}{c_{2, T}}}(I A+0.01)^{\frac{c_{3, T}}{c_{2, T}}}(\Delta I A+0.01)^{\frac{-c_{4, T}}{c_{2, T}}}
$$

the density distribution model is rearranged as 
Table 7. Smoothed values of the adjustment model coefficients and exponents.

[Variables for all models are defined in equations 12-18.]

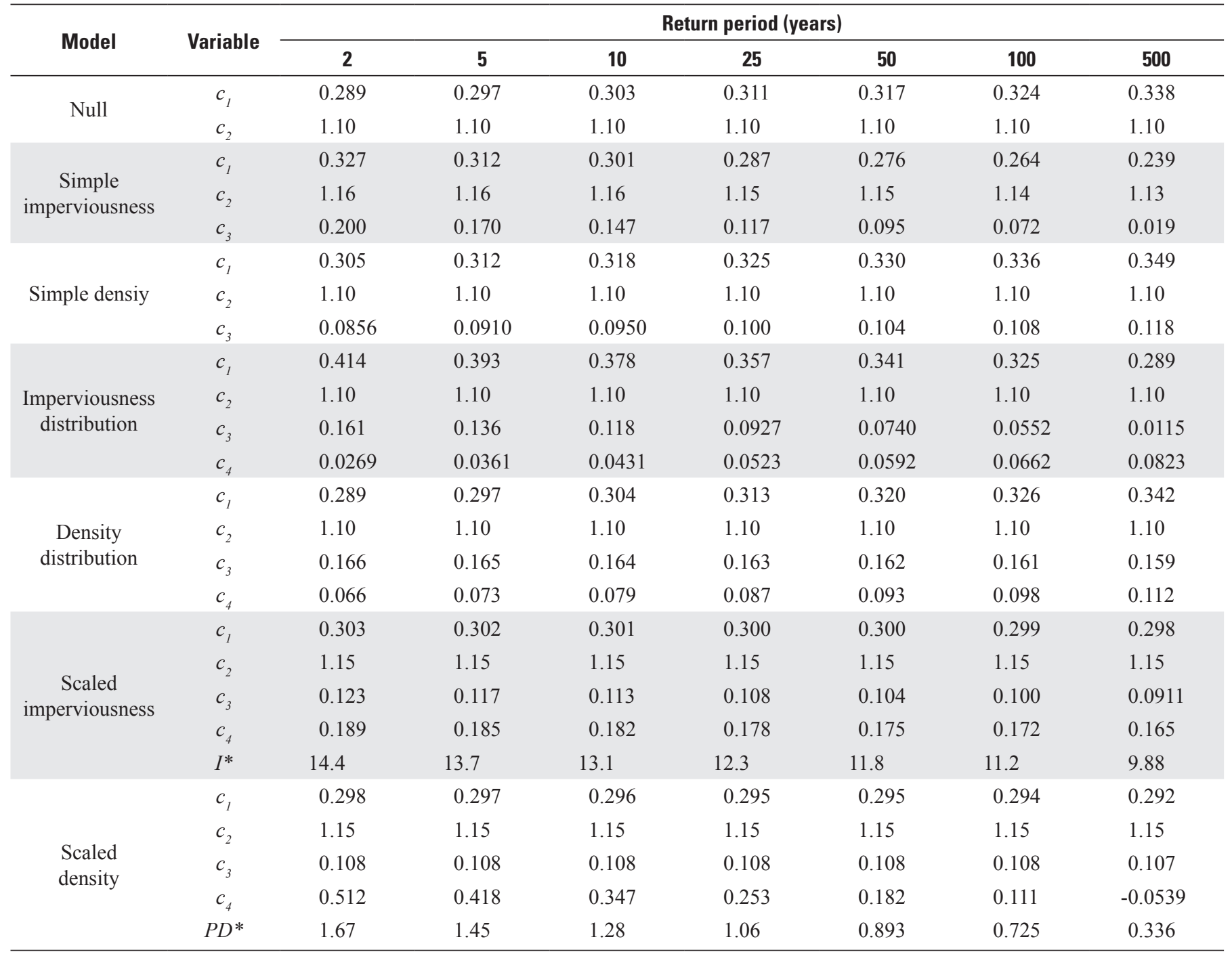

$$
U Q_{T}=\left(\frac{1}{c_{1, T}}\right)^{\frac{1}{c_{2, T}}} R Q_{T}^{\frac{1}{c_{2, T}}}(P D+0.001)^{\frac{c_{3, T}}{c_{2, T}}}(\Delta P D+0.001)^{\frac{-c_{4, T}}{c_{2, T}}},
$$

the scaled imperviousness model is rearranged as

$$
U Q_{T}=\left(\frac{1}{c_{1, T}}\right)^{\frac{1}{c_{1, T}}} R Q_{T}^{\frac{1}{c_{2, T}}}\left[1+\frac{99}{1+e^{c_{4, T}\left(I_{T}^{*}-I A\right)}}\right]^{\frac{c_{3, T}}{c_{2, T}}},
$$

and the scaled density model is rearranged as

$$
U Q_{T}=\left(\frac{1}{c_{1, T}}\right)^{\frac{1}{c_{1, T}}} R Q_{T}^{\frac{1}{c_{2, T}}}\left[1+\frac{99}{1+e^{c_{4, T}\left(P D_{T}^{*}-P D\right)}}\right]^{\frac{c_{3, T}}{c_{2, T}}},
$$

where IA is the impervious area, in percent, for the watershed conditions at which the urban discharge estimate is desired. 


\section{Methods for Adjusting USGS Rural Regression Peak Discharges in an Urban Setting}

The coefficients and (or) exponents, $c_{x, T}$, refer to the coefficients outlined in the models presented in equations 12-18 for the $T$-year prediction equation. Note that equations 12-18 refer to adjustment models that convert urbanized discharges to equivalent rural ones, whereas equations 33-40 convert rural discharges to urban ones.

Based on the smoothed coefficients and (or) exponents given in table 7, seven sets of urban equations are given based on the calibrated null, simple imperviousness, simple density, imperviousness distribution, density distribution, scaled imperviousness, and scaled density adjustment models. For the null model, the resulting urban equations are as follows:

$$
\begin{gathered}
U Q_{2}=3.091 R Q_{2}^{0.909} \\
U Q_{5}=3.014 R Q_{5}^{0.909}, \\
U Q_{10}=2.959 R Q_{10}^{0.909}, \\
U Q_{25}=2.889 R Q_{25}^{0.909}, \\
U Q_{50}=2.838 R Q_{50}^{0.909}, \\
U Q_{100}=2.790 R Q_{100}^{0.909},
\end{gathered}
$$

and

$$
U Q_{500}=2.683 R Q_{500}^{0.909} .
$$

The calibrated urban equations for the simple imperviousness model are as follows:

$$
\begin{gathered}
U Q_{2}=2.614 R Q_{2}^{0.859}(I A+1)^{0.172}, \\
U Q_{5}=2.866 R Q_{5}^{0.862}(I A+1)^{0.147} \\
U Q_{10}=2.827 R Q_{10}^{0.866}(I A+1)^{0.128} \\
U Q_{25}=2.965 R Q_{25}^{0.870}(I A+1)^{0.102} \\
U Q_{50}=3.080 R Q_{50}^{0.873}(I A+1)^{0.0825} \\
U Q_{100}=3.206 R Q_{100}^{0.876}(I A+1)^{0.0628}
\end{gathered}
$$

and

$$
U Q_{500}=3.541 R Q_{500}^{0.883}(I A+1)^{0.0166}
$$

The calibrated urban equations for the simple density model are as follows:

$$
U Q_{2}=2.941 R Q_{2}^{0.909}(P D+0.001)^{0.0778},
$$




$$
\begin{aligned}
& U Q_{5}=2.880 R Q_{5}^{0.909}(P D+0.001)^{0.0827}, \\
& U Q_{10}=2.835 R Q_{10}^{0.909}(P D+0.001)^{0.0864}, \\
& U Q_{25}=2.778 R Q_{25}^{0.909}(P D+0.001)^{0.0912}, \\
& U Q_{50}=2.737 R Q_{50}^{0.909}(P D+0.001)^{0.0948}, \\
& U Q_{100}=2.697 R Q_{100}^{0.909}(P D+0.001)^{0.0985},
\end{aligned}
$$

and

$$
U Q_{500}=2.607 R Q_{500}^{0.909}(P D+0.001)^{0.107} .
$$

The calibrated urban equations for the imperviousness distribution model are as follows:

$$
\begin{gathered}
U Q_{2}=2.230 R Q_{2}^{0.909}(I A+0.01)^{0.147}(\Delta I A+0.01)^{-0.0245}, \\
U Q_{5}=2.336 R Q_{5}^{0.909}(I A+0.01)^{0.124}(\Delta I A+0.01)^{-0.0328}, \\
U Q_{10}=2.424 R Q_{10}^{0.909}(I A+0.01)^{0.107}(\Delta I A+0.01)^{-0.0392}, \\
U Q_{25}=2.552 R Q_{25}^{0.909}(I A+0.01)^{0.0843}(\Delta I A+0.01)^{-0.0475}, \\
U Q_{50}=2.659 R Q_{50}^{0.909}(I A+0.01)^{0.0673}(\Delta I A+0.01)^{-0.0538}, \\
U Q_{100}=2.775 R Q_{100}^{0.909}(I A+0.01)^{0.0502}(\Delta I A+0.01)^{-0.0602},
\end{gathered}
$$

and

$$
U Q_{500}=3.091 R Q_{500}^{0.909}(I A+0.01)^{0.0105}(\Delta I A+0.01)^{-0.0748} .
$$

The calibrated urban equations for the density distribution model are as follows:

$$
\begin{gathered}
U Q_{2}=3.095 R Q_{2}^{0.909}(P D+0.001)^{0.151}(\Delta P D+0.001)^{-0.0598}, \\
U Q_{5}=3.011 R Q_{5}^{0.909}(P D+0.001)^{0.150}(\Delta P D+0.001)^{-0.0667}, \\
U Q_{10}=2.951 R Q_{10}^{0.909}(P D+0.001)^{0.149}(\Delta P D+0.001)^{-0.0720}, \\
U Q_{25}=2.875 R Q_{25}^{0.909}(P D+0.001)^{0.148}(\Delta P D+0.001)^{-0.0789}, \\
U Q_{50}=2.820 R Q_{50}^{0.909}(P D+0.001)^{0.147}(\Delta P D+0.001)^{-0.0841},
\end{gathered}
$$




$$
U Q_{100}=2.767 R Q_{100}^{0.909}(P D+0.001)^{0.146}(\Delta P D+0.001)^{-0.0894},
$$

and

$$
U Q_{500}=2.653 R Q_{500}^{0.909}(P D+0.001)^{0.145}(\triangle P D+0.001)^{-0.102} .
$$

For the scaled imperviousness model, the calibrated urban equations are as follows:

$$
\begin{gathered}
U Q_{2}=2.828 R Q_{5}^{0.870}\left[1+\frac{99}{1+e^{0.189(14.4-I A)}}\right]^{0.107}, \\
\left.U Q_{5}=2.834 R Q_{5}^{0.870}\right]^{0.102}, \\
\left.U Q_{10}=2.839 \cdot R Q_{10}^{0.870} \cdot\left[1+\frac{99}{1+e^{0.185(13.7-I A)}}\right]^{0.182(13.1-I A)}\right]^{0.0985}, \\
U Q_{25}=2.846 R Q_{25}^{0.870}\left[1+\frac{99}{1+e^{0.178(12.3-I A)}}\right]^{0.0940}, \\
U Q_{50}=2.851 R Q_{50}^{0.870}\left[1+\frac{99}{1+e^{0.175(11.8-I A)}}\right]^{0.0905}, \\
U Q_{100}=2.855 R Q_{100}^{0.870}\left[1+\frac{99}{1+e^{0.172(11.2-I A)}}\right]^{0.0871},
\end{gathered}
$$

and

$$
U Q_{500}=2.866 R Q_{500}^{0.870}\left[1+\frac{99}{1+e^{0.165(9.88-I A)}}\right]^{0.0792} .
$$

Finally, for the scaled density model, the calibrated urban equations are as follows:

$$
\begin{aligned}
& U Q_{2}=2.868 R Q_{2}^{0.870}\left[1+\frac{99}{1+e^{0.512(1.67-P D)}}\right]^{0.0942}, \\
& U Q_{5}=2.876 R Q_{5}^{0.870}\left[1+\frac{99}{1+e^{0.418(1.45-P D)}}\right]^{0.0940}, \\
& U Q_{10}=2.881 R Q_{10}^{0.870}\left[1+\frac{99}{1+e^{0.347(1.28-P D)}}\right]^{0.0939}, \\
& U Q_{25}=2.888 R Q_{25}^{0.870}\left[1+\frac{99}{1+e^{0.253(1.06-P D)}}\right]^{0.0937}, \\
& U Q_{50}=2.894 R Q_{50}^{0.870}\left[1+\frac{99}{1+e^{0.182(0.893-P D)}}\right]^{0.0936}, \\
& U Q_{100}=2.900 R Q_{100}^{0.870}\left[1+\frac{99}{1+e^{0.111(0.725-P D)}}\right]^{0.0935},
\end{aligned}
$$

and

$$
U Q_{500}=2.913 R Q_{500}^{0.870}\left[1+\frac{99}{1+e^{-0.0539(0.336-P D)}}\right]^{0.0931} .
$$

A positive exponent on any predictor variable indicates a positive relation between that predictor and the urban discharge; a negative exponent indicates a negative relation. All of the model forms have positive exponents on all predictors except the $\triangle I A$ and $\triangle P D$ terms (eqs. 62-75), which have negative exponents. (One other exception, which will be discussed later, occurred for $c_{4}$ in equation 89.) It can be concluded quickly that all exponents are rational because the urban flood magnitude is expected 
to increase with increasing rural flood magnitude, increasing imperviousness, and increasing population density. Although the negative sign on the $\triangle I A$ and $\triangle P D$ terms is less obvious, it indicates that as the watershed becomes more varied spatially in urbanization, the predicted discharge decreases. In essence, the $\triangle I A$ and $\triangle P D$ terms serve to temper the $I A$ or $P D$ terms, which convey only the average imperviousness or population density in a watershed but not variability. Finally, the positive signs on the two parameters that control the scaled sigmoid function presented in figure 8 are worth noting.

Trends in the parameter values as return period increases also are important to examine. Generally, as the return period increases, one might expect to see diminishing effects of urbanization on flood magnitude. For example, the 2-year flood would be expected to have greater dependence on urbanization than the 100-year flood, and trends in the parameter values would be expected to support this. The following discussion focuses on the rationality of the trends for each model:

- Null model: The evaluation of trends in this model is not applicable.

- Simple imperviousness model: Trends in this model are entirely rational. The model has a negative trend in the $I A$ exponent.

- Simple density model: The positive trend in the $P D$ exponent for this model is not rational. This is of concern.

- Imperviousness distribution model: Trends in this model are entirely rational. The model has a positive trend in $\Delta I A$ exponent and a negative trend in the $I A$ exponent.

- Density distribution model: The trends in this model follow the same pattern as in the imperviousness distribution model, although the negative trend in the $P D$ exponent is weak.

- Scaled imperviousness: Trends in this model are entirely rational. The model has a negative trend in the scaled $I A$ exponent. It is not clear whether a positive or negative trend in the two scaled imperviousness terms is expected but both terms have negative trends, which is consistent with the trends in the analogous terms in the scaled density model.

- Scaled density: This model has a weak positive trend in the scaled $P D$ exponent. This is not rational, but because the trend is so weak, the non-rationality similarly is weak. The negative trend in $c_{4}$ actually leads to a slightly negative value for the 500-year flood. The physical interpretation of this result is not clear, and the trends for this model are of concern. Again, the trends in both terms in the scaled density model are negative, consistent with the analogous terms in the scaled imperviousness model.

The results of the rationality analysis are summarized as follows:

1. All models had rational signs in the urbanization (imperviousness $(I A)$ or population density $(P D)$ ) exponents.

2. All imperviousness models (simple, distribution, and scaled) had rational trends in the exponents.

3. Two population density models (simple and scaled) had one or more non-rational trends in the exponents. The results for these two models should be used with caution, if at all.

Each of the above equations (eqs. 41-89) was divided by $R Q_{T}$ to produce the ratio of urban to rural discharge $(U Q / R Q)$. Assuming a vector of rural flood-frequency values $\left(Q_{f f r r u a l}\right)$, the $U Q / R Q$ was determined as a function of varying imperviousness. To visualize results of this approach, each model was applied to values in two watersheds, one fairly large and one fairly small. The fairly large watershed $\left(102 \mathrm{mi}^{2}\right)$ was represented by USGS streamgage 01645000, Seneca Creek at Dawsonville, Maryland; the fairly small watershed $\left(2.2 \mathrm{mi}^{2}\right)$ was represented by USGS streamgage 01585200 , West Branch Herring Run at Idlewylde, Maryland. The $U Q / R Q$ ratios are shown in figures 9-12.

The three imperviousness models that were investigated have several common characteristics (figs. 9, 11). First, all models indicate a general decline in $U Q / R Q$, approaching 1 , as the return period increases. Because the effects of urbanization are most profound for small magnitude and high-frequency flooding events, the greatest adjustment ratios are required for the small return periods. Also, all models had a greater $U Q / R Q$ value as imperviousness increased. This was not surprising because, all things being equal, higher values of imperviousness would be expected to lead to greater urban discharges. In most cases, the null model results were roughly centered within the spread of imperviousness values and were considered representative of average imperviousness across the datasets evaluated (figs. 9, 11).

The three calibrated population density models were applied to discharge data from the two selected gaging stations to obtain the $U Q / R Q$ values across all return periods (figs. 10,12). The irrationality in the trend in the population density exponent in the simple density model is shown in figure 10A by the increasing spread of the constant population density traces in relation to return period increases. The tight clustering of the constant population density traces in figure 10C indicates that the calibrated parameters for the scaled population density term do not lead to greatly varying estimates of scaled population density. This is not irrational, but it diminishes the credibility of the scaled population density model. 


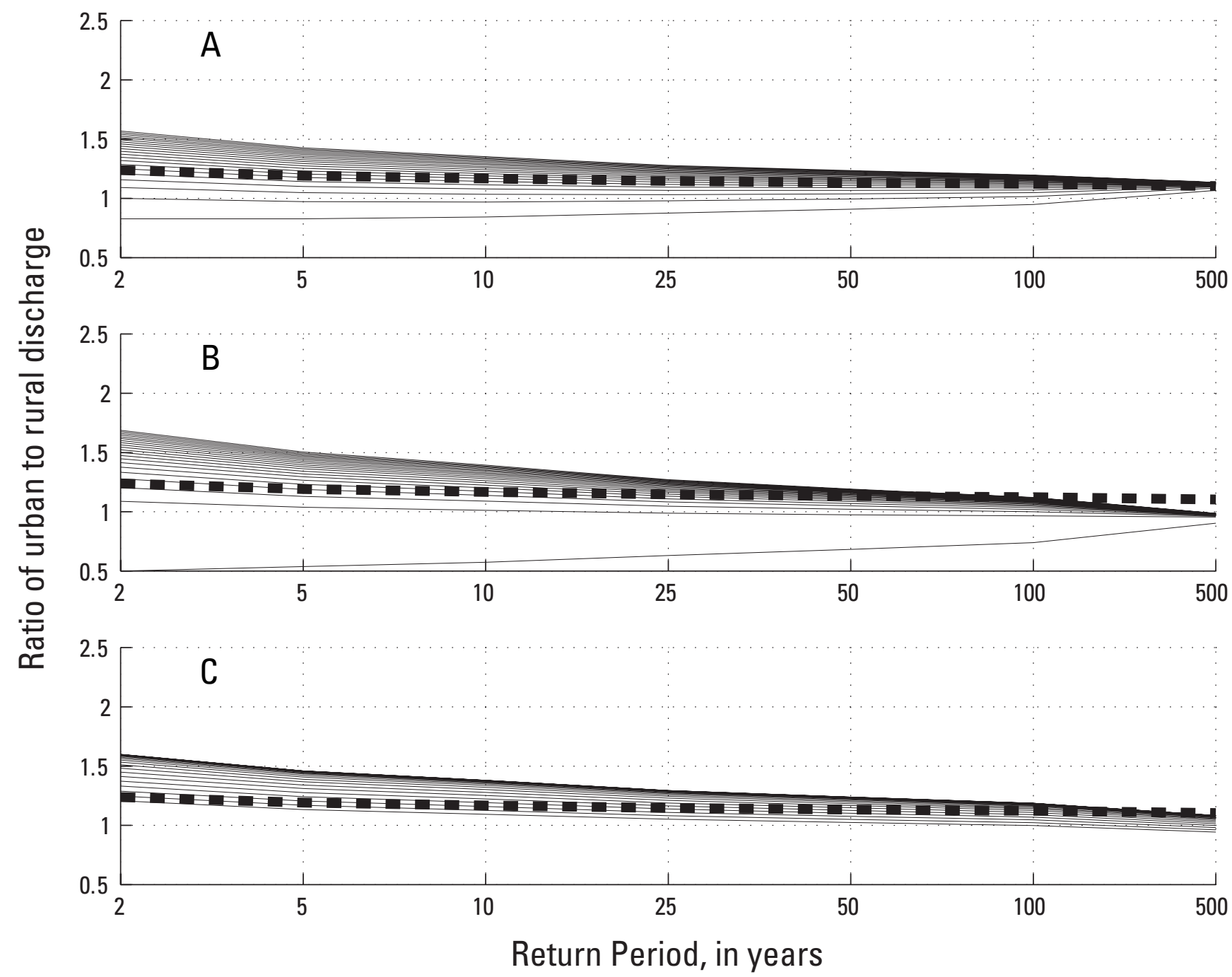

Figure 9. Application of the (A) simple imperviousness model, (B) imperviousness distribution model, and (C) scaled imperviousness model to the ratio of urban to rural discharges as a function of return period and imperviousness at U.S. Geological Survey streamgage 01645000, Seneca Creek at Dawsonville, Maryland. [The heavy dashed line shows the ratio for the "null" model. The light lines indicate imperviousness increasing in 2-percent increments starting from 0 percent for the lowest trace.] 


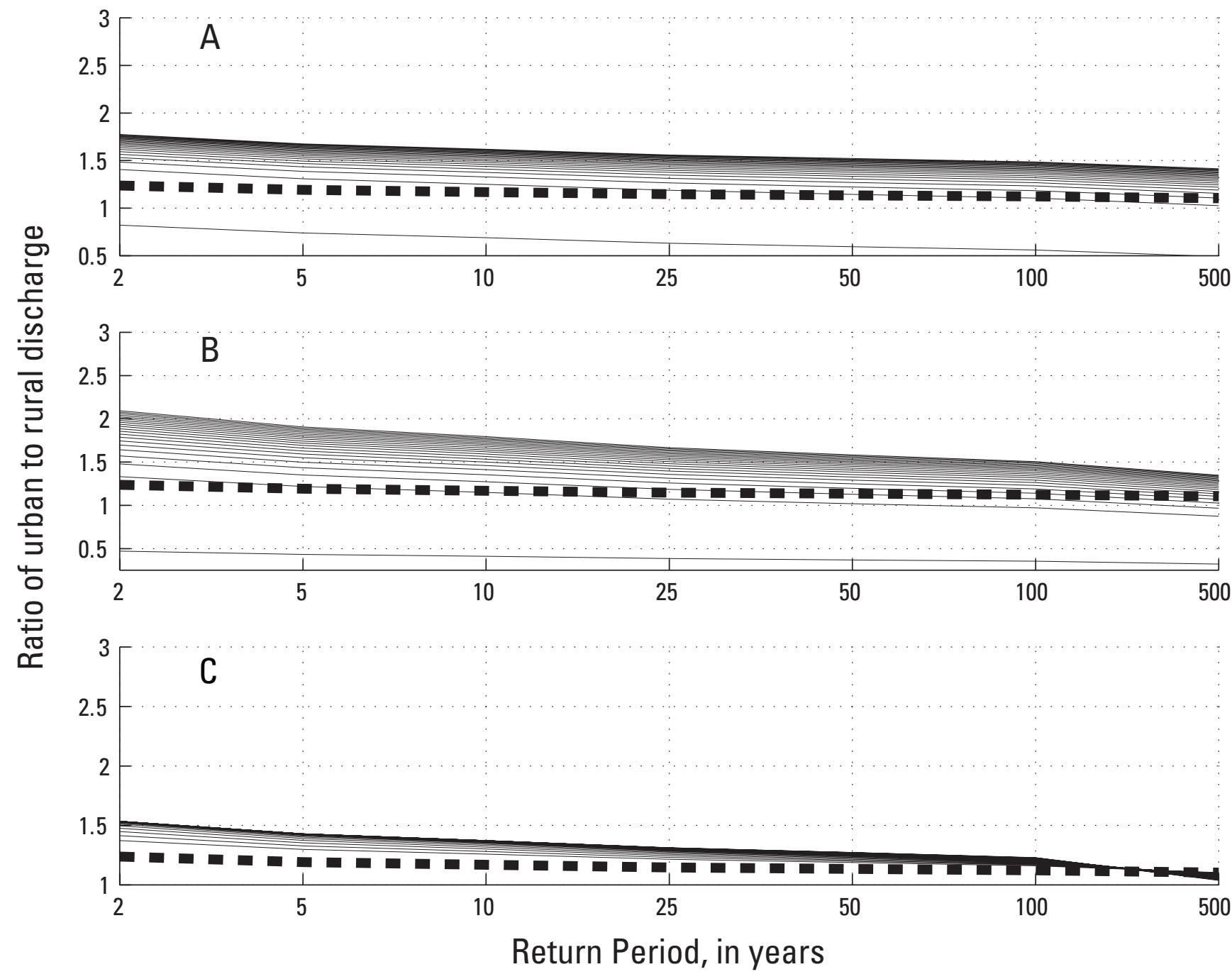

Figure 10. Application of the (A) simple density model, (B) density distribution model, and (C) scaled density model to the ratio of urban to rural discharges as a function of return period and imperviousness at U.S. Geological Survey streamgage 01645000, Seneca Creek at Dawsonville, Maryland. [The heavy dashed line shows the ratio for the "null" model. The light lines indicate population density increasing in increments of 1,000 persons per square mile starting from 0 persons per square mile for the lowest trace.] 


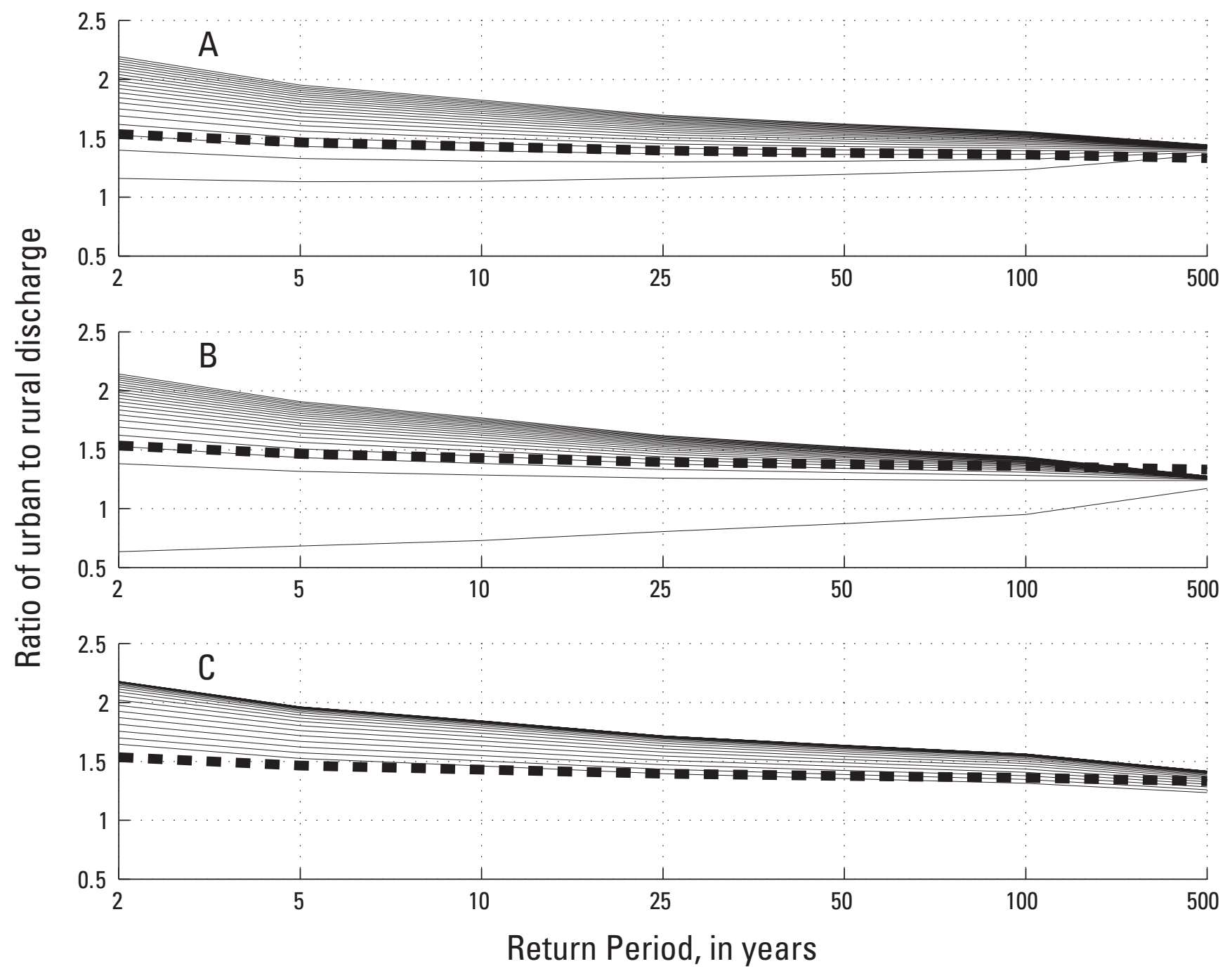

Figure 11. Application of the (A) simple imperviousness model, (B) imperviousness distribution model, and (C) scaled imperviousness model to the ratio of urban to rural discharges as a function of return period and imperviousness at U.S. Geological Survey streamgage 01585200, West Branch Herring Run at Idlewylde, Maryland. [The heavy dashed line shows the ratio for the "null" model. The light lines indicate imperviousness increasing in 2-percent increments starting from 0 percent for the lowest trace.] 


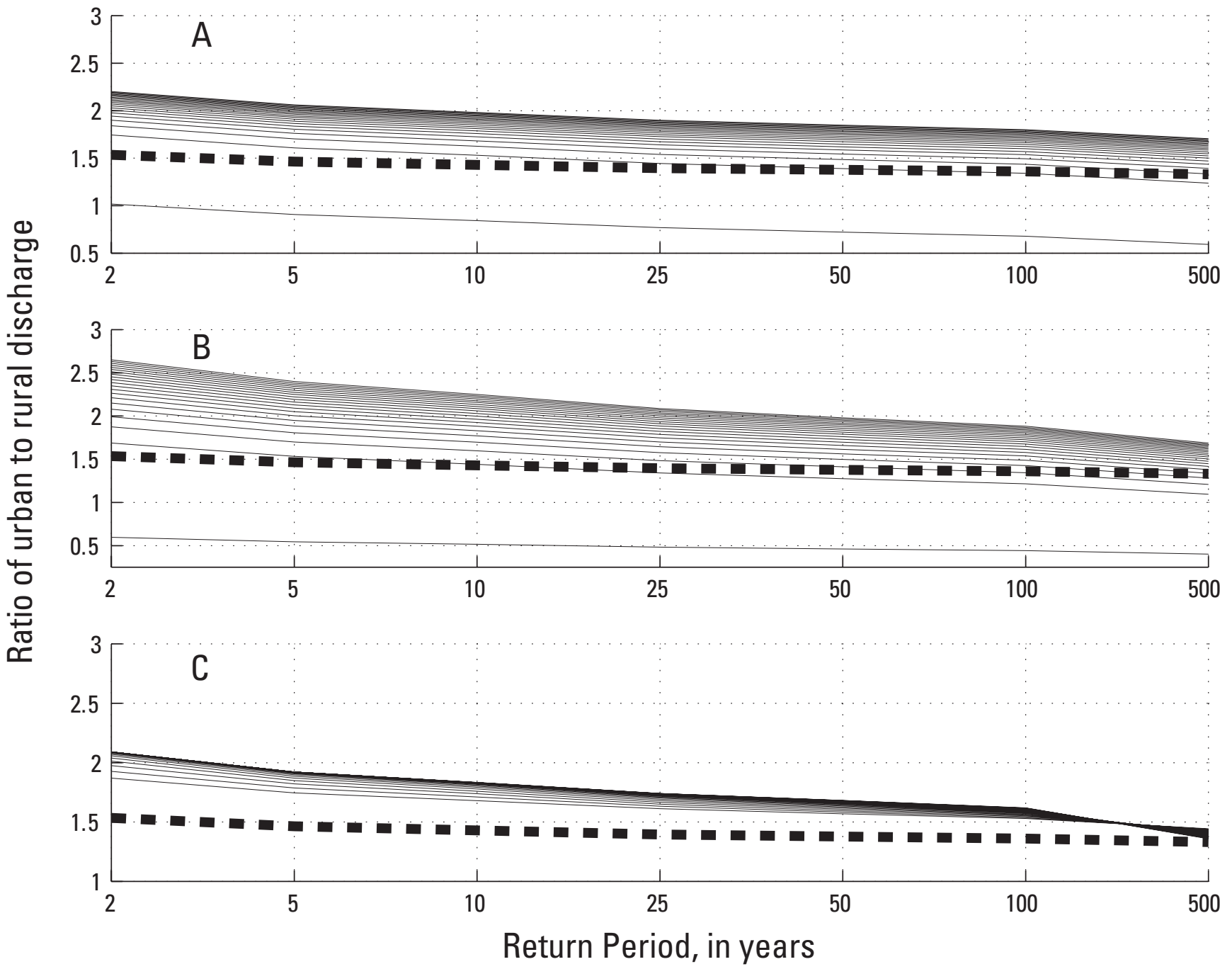

Figure 12. Application of the (A) simple density model, (B) density distribution model, and (C) scaled density model to the ratio of urban to rural discharges as a function of return period and imperviousness at U.S. Geological Survey streamgage 01585200, West Branch Herring Run at Idlewylde, Maryland. [The heavy dashed line shows the ratio for the "null" model. The light lines indicate population density increasing in increments of 1,000 persons per square mile starting from 0 persons per square mile for the lowest trace.] 
By comparing the $U Q / R Q$ ratios for imperviousness (figs. 9, 11) and population density (figs. 10,12) in the two watersheds, the effect of watershed scale is apparent between the two datasets. Herring Run is roughly two orders of magnitude smaller than Seneca Creek, which results in a greater range in $U Q / R Q$ ratios for this smaller watershed. In comparing figures 9A and $11 \mathrm{~A}$ for the 2-year return period, a $U Q / R Q$ range is observed of 0.8 to 1.6 for Seneca Creek and approximately 1.2 to 2.2 for Herring Run, respectively. The greater range in $U Q / R Q$ ratios for the smaller watershed is because the exponent on $R Q$, which is positive but less than 1 , has the effect of the $U Q / R Q$ ratio varying more widely for small discharges associated with small watersheds.

\section{Comparison to Urban Equations Developed by Sauer and others (1983)}

Application of the urban equations in Sauer and others (1983) to the database assembled for this current study was not possible because all of the equations developed in the earlier work included many watershed characteristics that were not gathered for the current study, most notably the basin development factor $(B D F)$. It is possible, however, to return to the dataset from Sauer and others (1983) and apply three of the equations generated in the current study.

The three equations represent the null model, the simple imperviousness model, and the scaled imperviousness model. The adjustment models that included population density and (or) imperviousness distribution as predictors could not be compared because these data were not measured or presented in the dataset generated by Sauer and others (1983). Another model was added, however; the "Sauer (null)" model is the analog of the null model presented in the current study. The Sauer (null) model was calibrated as a simple power model of the rural discharge,

$$
U Q_{T}=c_{1, T} R Q_{T}^{c_{2, T}}
$$

using a logarithmic transformation of the rural and urban discharges and calibrating a linear model through least-squares regression. The purpose of the Sauer (null) model was to provide some perspective on the merits of the seven-parameter Sauer and others (1983) model relative to the simplest possible model.

The mean bias and relative standard error were examined for the seven-parameter model (Sauer and others, 1983), the Sauer (null) model, and the three models developed in the current study as applied to the seven return periods (table 8). For the purposes of this report, mean bias was calculated as the average difference between predicted discharges (from the equations developed in this report) and observed urban flood-frequency (reported by Sauer and others, 1983).

In general, the equations from Sauer and others (1983) performed best in predicting urban discharges across the 203 streamgages in the study, especially in terms of standard error (table 8). This would be expected because Sauer and others (1983) used these gages to calibrate their equations. Although the three new models calibrated in the current study did not make use of the database from Sauer and others (1983), the prediction ability of these new models was respectable as evidenced by similar, albeit slightly poorer, bias and standard error values (table 8). This is somewhat surprising in that this comparison is not exactly fair given the possibility for systematic differences in the way imperviousness was measured in the two studies and the fact that this is the calibration set for the Sauer and others (1983) equations. Further, the Sauer (null) model shows comparable relative standard error performance for the 25- through 500-year return periods. The complexity of the seven-parameter model from Sauer and others (1983) seems to yield meaningfully better predictions relative to the other models only for the 2-, 5-, and 10 -year return periods. Finally, the performance of the new models developed in this study is even more impressive when considering the use of only two predictors (rural discharge and imperviousness) in these models.

To further quantify the performance of the three models developed in this (current) study, the relative standard errors of each of the new models (null, simple, and scaled) were normalized by the relative standard error from the seven-parameter Sauer and others (1983) model for the same return period. Each of the three new models performed similarly across all return periods (table 9). On average, the standard error of the three new models was about 6 to 9 percent greater than the equivalent standard error from Sauer and others (1983). Standard error is not uniform across return periods, however, but tends to decrease as the return period increases.

This finding mirrors the performance of the Sauer (null) model, which produced poorer relative standard errors for the 2-, 5-, and 10-year return periods and then was essentially equivalent in relative standard error to the seven-parameter model (Sauer and others, 1983) for all larger flood events. 
Table 8. Performance of U.S. Geological Survey urban equations from an earlier study and urban equations developed in this report.

[Bold values indicate overall best model performance. Italic values indicate best model performance developed in this report. ft $\mathrm{f}^{3} / \mathrm{s}$, cubic feet per second]

\begin{tabular}{|c|c|c|c|c|c|c|c|c|c|c|}
\hline \multicolumn{6}{|c|}{ Mean bias $\left(\mathrm{ft}^{3} / \mathrm{s}\right)$} & \multicolumn{5}{|c|}{ Relative standard error: $S_{\mathrm{e}} / S_{\mathrm{y}}$} \\
\hline $\begin{array}{l}\text { Return } \\
\text { period } \\
\text { (years) }\end{array}$ & $\begin{array}{l}\text { Sauer } \\
\text { (null) }\end{array}$ & Sauer* & Null & Simple & Scaled & $\begin{array}{l}\text { Sauer } \\
\text { (null) }\end{array}$ & Sauer* & Null & Simple & Scaled \\
\hline 2 & -127 & -111 & -33 & -111 & 32 & 0.462 & 0.381 & 0.486 & 0.461 & 0.461 \\
\hline 5 & -171 & -178 & -80 & -214 & 6 & 0.463 & 0.425 & 0.466 & 0.477 & 0.467 \\
\hline 10 & -235 & -141 & -174 & -285 & -65 & 0.474 & 0.449 & 0.474 & 0.496 & 0.481 \\
\hline 25 & -357 & -289 & -388 & -455 & -241 & 0.493 & 0.490 & 0.496 & 0.523 & 0.507 \\
\hline 50 & -537 & -281 & -553 & -644 & -377 & 0.520 & 0.518 & 0.521 & 0.550 & 0.534 \\
\hline 100 & -675 & -300 & -867 & -734 & -658 & 0.532 & 0.533 & 0.540 & 0.573 & 0.555 \\
\hline 500 & $-1,200$ & $-1,150$ & $-1,748$ & $-1,106$ & $-1,458$ & 0.600 & 0.600 & 0.600 & 0.586 & 0.612 \\
\hline
\end{tabular}

*Sauer and others, 1983.

Table 9. Relative Standard error $\left(S_{\mathrm{e}} / S_{\mathrm{y}}\right)$ for three imperviousness models developed in this report as normalized by the relative standard error determined by Sauer and others (1983).

\begin{tabular}{cccc|c}
\hline $\begin{array}{c}\text { Return } \\
\text { period } \\
\text { (years) }\end{array}$ & Null & Simple & Scaled & Mean \\
\hline 2 & 1.244 & 1.218 & 1.205 & 1.223 \\
5 & 1.094 & 1.146 & 1.106 & 1.115 \\
10 & 1.047 & 1.120 & 1.078 & 1.082 \\
25 & 1.004 & 1.073 & 1.040 & 1.039 \\
50 & 1.002 & 1.052 & 1.034 & 1.029 \\
100 & 1.016 & 1.048 & 1.048 & 1.037 \\
500 & 1.000 & 0.976 & 1.020 & 0.999 \\
\hline Mean & 1.058 & 1.090 & 1.076 & 1.075 \\
\hline & & & &
\end{tabular}




\section{Application of Calibrated Models to Streamgages with Local Urban Equations}

A total of 10 USGS streamgages were identified in New Jersey (Stankowski, 1974), Pennsylvania (Stuckey and Reed, 2000), and Wisconsin (Walker and Krug, 2003) that were subject to substantial urbanization. A set of USGS peak flow regression equations that include an imperviousness or urbanization descriptor is available for each of these States. For each of the 10 urban streamgages, watershed characteristics were determined and regression equations were applied twice-first, to obtain the best estimate of the current urban flow, and second, to set the urban descriptor (either imperviousness or urban area) at zero to develop an equivalent rural flow. The watershed characteristics for the 10 streamgages are provided in appendix 5 , and the rural and urban flood-frequency results are provided in appendix 6.

The following example is given for USGS streamgage 01393450, Elizabeth at Ursino Lake at Elizabeth, New Jersey. The 2-year USGS regression equation for New Jersey is as follows:

$$
Q_{2}=25.6 A^{0.89} S^{0.25}(S T+1)^{-0.56}(I+1)^{0.25},
$$

where the constants of 1 are added by default on the chance that either of these quantities would be zero for a particular watershed being studied. For USGS streamgage 01393450, the drainage area is $17.6 \mathrm{mi}^{2}$, the channel slope is 22.4 feet per mile, the storage is 1.6 percent, and the imperviousness in 2000 was 41.9 percent. The result of applying equation 91 to these values is an urban 2-year discharge of $1,071 \mathrm{ft}^{3} / \mathrm{s}$. If imperviousness is set at zero (actually 1, as applied in the National Flood-Frequency program), the equivalent rural discharge is $550 \mathrm{ft}^{3} / \mathrm{s}$.

To test the quality of the urban equation models calibrated in this study, the urban equations were applied to the equivalent rural discharge, and the result was compared with the urban value of $1,071 \mathrm{ft}^{3} / \mathrm{s}$. Continuing this example, the simple imperviousness model was applied as follows:

$$
U Q_{2}=2.614(550)^{0.859}(41.9+1)^{0.172}=1,127 \mathrm{ft}^{3} / \mathrm{s} .
$$

The result of $1,127 \mathrm{ft}^{3} / \mathrm{s}$ was compared with the estimated $1,071 \mathrm{ft}^{3} / \mathrm{s}$ from equation 91 . Similar comparisons were made for the other nine streamgages, and the mean bias results are presented in table 10 and the relative standard error results are presented in table 11 .

The performance of the models was ranked in the same way as the model calibrations. The sums of ranks for both the mean bias and relative standard error for the performance of the models for the 10 streamgages with local urban equations are given in table 12. Here, mean bias is defined as the average difference between the predicted discharges determined by applying the equations developed in this study and the discharges determined by applying the appropriate (published) State urban regression equations. The strongest performing models were models based on population density; however, all models outperform the null model, which indicates the genuine predictive capabilities that these models offer beyond a simplistic scaling up of a rural discharge.

Table 10. Mean bias, in cubic feet per second, for new urban equations used on data from 10 U.S. Geological Survey streamgages for which localized urban equations are available.

\begin{tabular}{|c|c|c|c|c|c|c|c|}
\hline \multirow{2}{*}{$\begin{array}{l}\text { Return period } \\
\text { (years) }\end{array}$} & \multirow[b]{2}{*}{ Null } & \multicolumn{2}{|c|}{ Simple } & \multicolumn{2}{|c|}{ Distribution } & \multicolumn{2}{|c|}{ Scaled } \\
\hline & & $\begin{array}{c}\text { Impervious- } \\
\text { ness }\end{array}$ & Density & $\begin{array}{c}\text { Impervious- } \\
\text { ness }\end{array}$ & Density & $\begin{array}{c}\text { Impervious- } \\
\text { ness }\end{array}$ & Density \\
\hline 5 & -587 & -431 & -417 & -506 & -392 & -491 & -383 \\
\hline 10 & -592 & -503 & -345 & -541 & -380 & -473 & -305 \\
\hline 100 & -385 & -77 & 248 & -569 & -231 & -180 & 341 \\
\hline 500 & 62 & 803 & 1165 & -406 & 55 & 336 & $-1,708$ \\
\hline
\end{tabular}

[Bold values indicate overall best model performance.] 
Table 11. Relative standard error $\left(S_{\mathrm{e}} / S_{\mathrm{y}}\right)$ for new urban equations used on data from 10 U.S. Geological Survey streamgages for which localized urban equations are available.

[Bold values indicate overall best model performance.]

\begin{tabular}{cccccccc}
\hline \multirow{2}{*}{$\begin{array}{c}\text { Return period } \\
\text { (years) }\end{array}$} & Null & $\begin{array}{c}\text { Impervious- } \\
\text { ness }\end{array}$ & Density & $\begin{array}{c}\text { Simple } \\
\text { Imess }\end{array}$ & $\begin{array}{c}\text { Distribution } \\
\text { Density }\end{array}$ & $\begin{array}{c}\text { Impervious- } \\
\text { ness }\end{array}$ & $\begin{array}{c}\text { Density } \\
\text { Dess }\end{array}$ \\
\hline 2 & 0.486 & 0.454 & 0.409 & 0.417 & $\mathbf{0 . 3 7 8}$ & 0.500 & 0.428 \\
5 & 0.361 & 0.284 & 0.252 & 0.311 & $\mathbf{0 . 2 4 9}$ & 0.376 & 0.280 \\
10 & 0.298 & 0.262 & $\mathbf{0 . 1 7 8}$ & 0.271 & 0.200 & 0.311 & 0.202 \\
25 & 0.234 & 0.192 & 0.139 & 0.238 & 0.166 & 0.243 \\
50 & 0.201 & 0.160 & 0.174 & 0.221 & 0.162 & 0.209 \\
100 & 0.177 & $\mathbf{0 . 1 5 6}$ & 0.236 & 0.202 & 0.162 & 0.184 & $\mathbf{0 . 1 4 8}$ \\
500 & 0.218 & 0.307 & 0.439 & $\mathbf{0 . 1 8 4}$ & 0.209 & 0.196 \\
\hline
\end{tabular}

Table 12. Summed and ranked overall performance of new urban equations used on data from 10 U.S. Geological Survey streamgages for which localized urban equations are available.

[Smaller sums and lower ranks indicate best performance.]

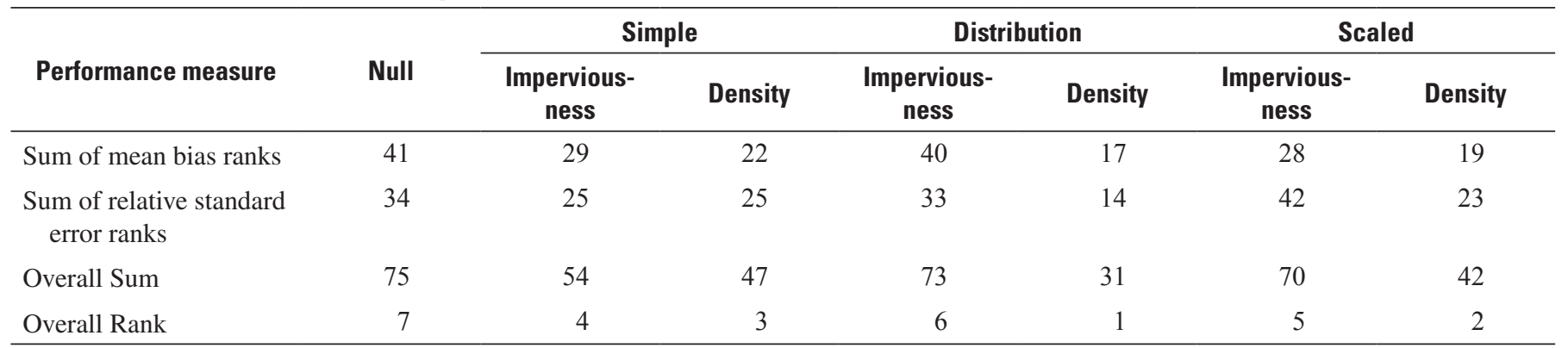

\section{Interpretation of Results}

The equations developed in this study appear to be comparable in predictive capability to those developed by Sauer and others (1983). Three models developed during this current study — the null, simple imperviousness, and scaled imperviousness models - were compared with the best model from the Sauer and others (1983) study. The simple and scaled imperviousness models performed, on average, within about 6 to 9 percent of the results obtained by Sauer and others (1983). The model performance for the more frequent return periods, however, was not as strong. The relative standard error was about 20 to 24 percent greater for the 2-year return period, 10 to 15 percent greater for the 5-year return period, and 5 to 12 percent greater for the 10-year return period that the results obtained by Sauer and others (1983). These results are considered comparable because the statistics from Sauer and others (1983) were based on performance using the same dataset from which the equations were calibrated, and the new models were calibrated using a completely different dataset.

\section{Model Strengths}

The models developed in this study have two key strengths

- Simplicity: The equations require three predictors or less. The rural discharge is a predictor in all models. Imperviousness or population density is used as a predictor in all but the null model. The quantities $\triangle I A$ and $\triangle P D$ are used as third predictors in the distribution models to quantify the heterogeneity of urbanization within a watershed. Although $\triangle I A$ and $\triangle P D$ qualify as third predictors, they are based directly on the same quantities as either imperviousness or population 
density. A user of any of these models needs access only to the rural discharges and a representation of either imperviousness or population density.

- Ease of Use/GIS friendly: These models are applied easily by using available data from remote locations. The water, environmental, and ecological communities increasingly recognize the value of imperviousness as a strong predictor of human effects; simultaneously, the availability and quality of GIS coverages of imperviousness are increasing (Homer and others, 2004). Similarly, GIS coverages of census data are available commonly and render the determination of population density and $\triangle P D$ to an easily automated task. In contrast, the equations from Sauer and others (1983) require the determination of seven predictors, of which at least one (BDF) requires a physical reconnaissance of the watershed for accurate determination.

\section{Model Weaknesses}

The principal weakness of the models developed in this study is the relatively mild dependency of flood magnitude on imperviousness or population density. This mild dependency is underscored by the good performance of the calibrated null model and on the non-smoothness of the calibrated adjustment model parameters shown in table 6 . If this method were expanded to more gages or repeated with longer time series as additional data become available, it may be the case that the functional dependency on urbanization measures would become more clear and the need for calibrated model parameter smoothing (shown in table 7) would diminish.

Another weakness of the models, which is apparent from the comparison to data from Sauer and others (1983; see table 8) and to the locally available urban equations (table 10), is a clearly negative bias in the errors of all models for the small return periods. A shift to a positive bias occurred for the largest return periods (table 10). The origin of this bias is not known with certainty, although it may be a result of the model calibration method which depends on a logarithmic transformation of the observed rural discharges. Because calibration takes place in the logarithmic space, positive and negative errors measured in the arithmetic space are unequal, and a negative bias can result.

\section{Choosing a Model}

Ultimately, the questions one faces are these: "Which is the best model form to use?" and "Are there models that are clearly superior or inferior to the others?"

- Population density approach: Among the models based on population density, the density distribution model (eqs. 69-75) was the best performer during calibration and testing with the local urban equations. Further, the other two sets of density-based equations had irrational exponent values or trends, which cast doubt on their application.

- Imperviousness approach: The choice of the best imperviousness model is less certain. The imperviousness distribution model (eqs. 62-68) performed the best overall during model calibration, but the performance of this model in testing the local urban equations was not as strong as for the simple imperviousness model (eqs. 48-54). This is perhaps attributable to the small sample size (10 streamgages) used for testing. Because of the clearly strong performance during model calibration and consistency with the population density approach, the imperviousness distribution models appear to be good choices if imperviousness data are used. 


\section{Summary and Conclusions}

In this study, a new approach was developed, using data from 78 urbanized streamgages across the United States, for calibrating a set of USGS urban regression equations. The rural flood-frequency was determined for each streamgage by using the best available GIS data. The annual maximum time series for the 31-year period, 1970-2000, formed the observed peak discharge portion of the dataset. GIS techniques were used to develop an annual time series of imperviousness over this period using census-derived population density as a surrogate and predictor of imperviousness. The PeakFQ program ${ }^{1}$ was embedded in a modified nonlinear optimization program, and several adjustment equations were investigated for calibrating adjustment equations that could scale-back the observed annual maximum time series to an equivalent rural annual maximum time series closely representative of the rural regression equation flood frequency. Seven adjustment models of varying degrees of complexity were calibrated. These models then were compared with earlier USGS urban equations and with urban flood-frequency equations for individual States.

The results indicate that the urban equations developed in this study are comparable in performance to the earlier USGS urban equations but are simpler in that they are dependent only on rural discharge and measures of either imperviousness or population density. Further, the new urban equations can be applied readily by using only remotely sensed data rather than requiring data that can only be measured during site visits to the watershed of interest.

The highest performing models emerging from this study are the imperviousness distribution models (eqs. 62-68) and the population density distribution models (eqs. 69-75). These models depend on three predictors each—rural discharge, imperviousness or population density, and delta imperviousness or delta population density. The imperviousness or population density predictor serves to scale up the rural discharge, and the delta imperviousness or delta population density predictor scales down the discharge. This delta predictor quantifies the homogeneity of the development in a watershed and is calculated readily by GIS techniques using the same spatial data used in determining the imperviousness or population density predictor.

Several directions are worth pursuing in future efforts to develop urban equations.

- Expand the model calibration database: The data collection for 78 gages used in this study was labor intensive but crucial to the development of nationally applicable regression equations. In contrast, the database for the Sauer and others (1983) urban equation study was slightly in excess of 200 streamgages. Although expanding the current database may be impractical (or impossible), more streamgages could be identified that have been active in recent (1970 to present) times in States for which no local urban equations have been developed. Alternatively, this dataset likely will improve with time as periods of record for urbanization data increase.

- Expand the test application database: Data for only 10 streamgages were used to compare locally available urban equations to predictions from the urban equations developed in this study. The results of this application are, therefore, only as sound as the representativeness of these 10 streamgages and the respective local urban equations. Local urban equations have been developed for approximately 13 States. Using data from streamgages in all of these States may lead to more definitive or possibly different results from those documented here.

- Investigate additional trial adjustment models: As previously stated, it is a logical impossibility to consider all possible models for relating urban floods to rural floods. In this study, a creative attempt was made in this regard. Other models, however, could be investigated and may prove more effective.

- Recalibrate model in compliance with Bulletin 17B: It is advisable that additional investigative work, using the embedded PeakFQ-optimization approach developed in this study, be done in compliance with the guidelines set forth in Bulletin 17B (Interagency Advisory Committee on Water Data, 1982).

- Investigate different optimization and calibration algorithms: The tendency for calibrated models (developed in this study and in the Sauer and others (1983) urban equation study) to have a negative bias for small return periods and a neutral or positive bias for large return periods indicates a weakness in the current log-transformation method. Using a different model calibration approach that avoids this log-transformation method may produce unbiased calibrations and ultimately smaller standard errors.

\footnotetext{
${ }^{1}$ In this study, a nonstandard treatment of the historical period was used in the PeakFQ program, and this approach does not fully comply with the procedures set forth in Bulletin 17B, as perviously noted. Therefore, modifications may be needed before this approach can be applied in practice.
} 


\title{
Notation
}

\author{
A drainage area of watershed (in square miles) \\ $B D F \quad$ basin development factor - a number between 0 and 12 (used in the Sauer and others (1983) urban equations) \\ that represents the degree of channel improvements, channel linings, storm drains or storm sewers, and curb \\ and gutter streets within the upper, middle, and lower third of the watershed \\ $C$ percentage of watershed underlain by carbonate rock (in Pennsylvania Region A flood regression equations (in \\ percent)) \\ CA percentage of the basin controlled by lakes, swamps, or reservoirs (in Pennsylvania Region A flood regression \\ equations (in percent)) \\ $c_{x, T} \quad$ calibrated coefficients or exponents corresponding to parameter $x$ and the $T$-year flood in one of the adjustment \\ equations \\ $F \quad$ forest cover (in percent) \\ $F F($.$) \quad flood-frequency operator in Bulletin 17B — produces a vector of flood-frequency discharge estimates (in units of$ \\ cubic feet per second) \\ $f_{T}($.$) \quad a discharge adjustment model for return period T$ \\ $f_{T}^{-1}($.$) \quad a discharge adjustment model for return period T$ \\ $H P \quad$ historical period used as input in Bulletin 17B flood-frequency analysis (in years) \\ IA impervious area within the watershed (in percent) \\ $I A_{x} \quad$ impervious area corresponding to the $x^{\text {th }}$ percentile of the distribution of imperviousness within the watershed \\ (in percent) \\ $I A(t) \quad$ impervious area within the watershed in year $t$ (in percent) \\ $\triangle I A \quad$ difference between the $10^{\text {th }}$ and $90^{\text {th }}$ percentile imperviousness values (in percent) \\ $\Delta I A(t) \quad$ difference between the $10^{\text {th }}$ and $90^{\text {th }}$ percentile imperviousness values in year $t$ (in percent) \\ $I_{T}^{*} \quad$ threshold impervious area for return period $T$ in equation 39 (in percent) \\ $m$ the number of coefficients and (or) exponents being calibrated in a discharge adjustment model \\ $n$ number of years in a gage record (in years) \\ $n \quad$ number of observations (gages) used in the calibration of a discharge adjustment model \\ $P\left(Q_{x}\right) \quad$ cumulative probability associated with having an annual maximum flood of magnitude $Q_{x}$ \\ $P D \quad$ population density (thousands of people per square mile) \\ $P D_{x} \quad$ population density corresponding to the $x^{\text {th }}$ percentile of the distribution of population density within the \\ watershed (thousands of people per square mile) \\ $P D(t) \quad$ population density in year $t$ (thousands of people per square mile) \\ $P D_{T}^{*} \quad$ threshold population density for return period $T$ in equation 40 (thousands of people per square mile) \\ $\triangle P D \quad$ difference between the $10^{\text {th }}$ and $90^{\text {th }}$ percentile population density values (thousands of people per square mile) \\ $\triangle P D(t) \quad$ difference between the $10^{\text {th }}$ and $90^{\text {th }}$ percentile population density values in year $t$ (thousands of people per \\ square mile) \\ $P_{T} \quad$ cumulative probability associated with the $T$-year annual maximum flood \\ $Q_{a d j}(t) \quad$ the generic adjusted annual maximum flood in year $t$ (in cubic feet per second) \\ $Q_{a d j, T}(t) \quad$ the $T$-year adjusted annual maximum flood in year $t$ (in cubic feet per second) \\ $Q_{f f}(T) \quad$ the $T$-year flood from a flood-frequency vector (in cubic feet per second) \\ $Q_{f f, r u r a l}$ \\ $Q_{\text {ffiurban }}$ \\ the rural flood-frequency vector (2-, 5-, 10-, 25-, 50-, 100-, and 500-year floods) (in cubic feet per second) \\ the urban flood-frequency vector (2-, 5-, 10-, 25-, 50-, 100-, and 500-year floods) (in cubic feet per second) \\ $Q_{f f, x}$ \\ the $x$ (rural or urban) flood-frequency vector (2-, 5-, 10-, 25-, 50-, 100-, and 500-year floods) (in cubic feet per \\ second) \\ $Q_{f f}(T) \quad$ the $T$-year flood discharge from flood-frequency analysis (in cubic foot per second) \\ $Q_{T} \quad$ the $T$-year flood discharge (in cubic foot per second) \\ $Q_{o b s}(t) \quad$ the observed annual maximum flood in year $t$ (in cubic foot per second) \\ $Q_{l} \quad$ lower bound flood-frequency discharge used in piecewise log-normal interpolation of high-outlier discharge \\ threshold (in cubic foot per second) \\ $Q_{\max } \quad$ the largest annual maximum flood in the systematic record of a streamgage (in cubic feet per second) \\ $Q_{o} \quad$ in flood-frequency analysis, the high-outlier threshold flood discharge (in cubic feet per second) \\ $Q_{u} \quad$ upper-bound flood-frequency discharge used in piecewise log-normal interpolation of high-outlier discharge \\ threshold (in cubic feet per second) \\ $R^{2} \quad$ explained variance of a calibrated regression equation
}




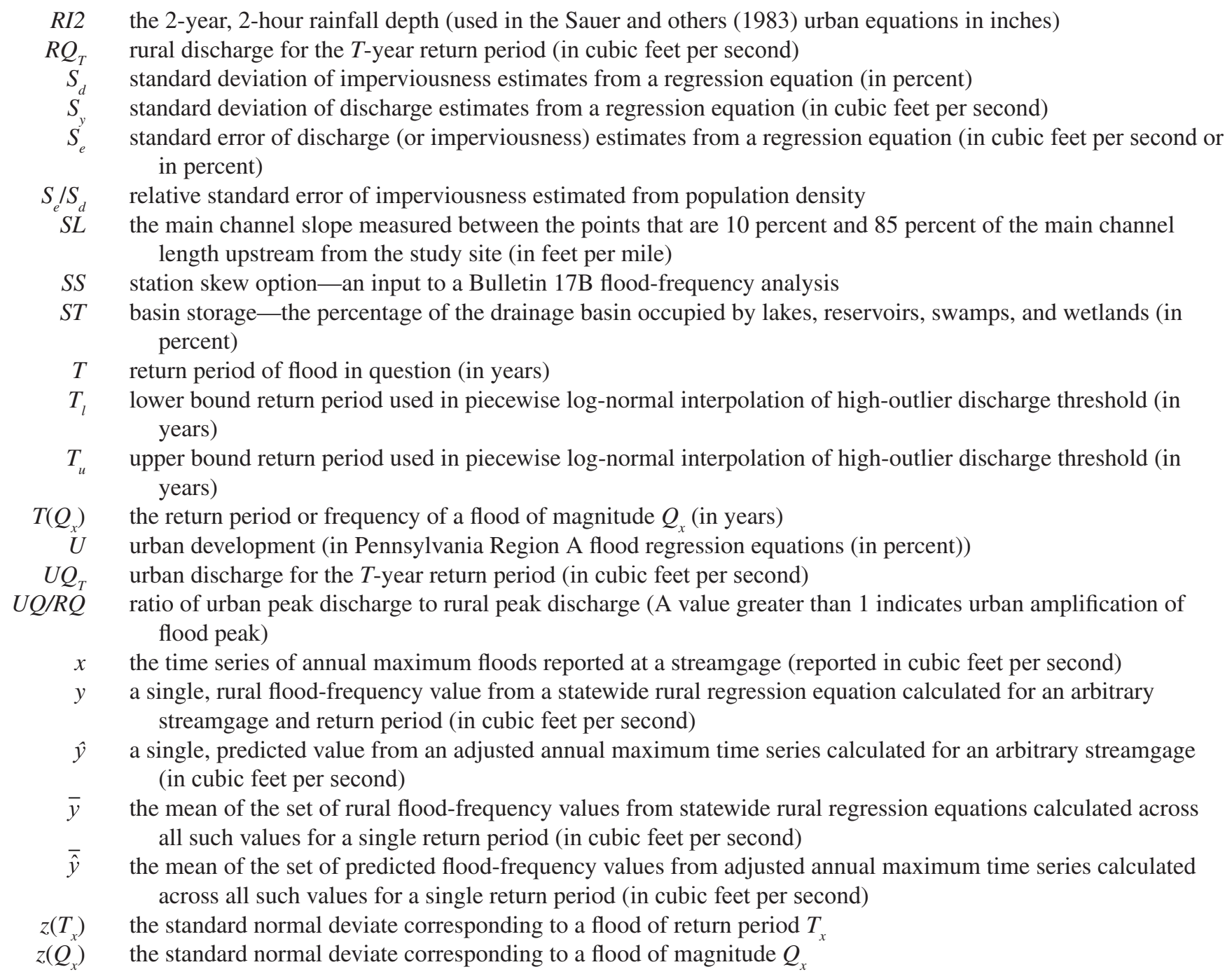

\section{Discharge Adjustment Model Definitions:}

Null: Urban discharges are a power function of rural discharges. The null model has no dependency on imperviousness, population density, or any other watershed characteristic. Because the model does not depend on any watershed characteristics, it is of little practical value by itself but is useful in comparison to other models being calibrated.

Simple Imperviousness: Urban discharges are a power function of rural discharges and percent imperviousness in a watershed.

Simple Density: Urban discharges are a power function of rural discharges and population density in a watershed.

Imperviousness Distribution: Urban discharges are a power function of rural discharges, percentage of imperviousness, and the difference in percentage of imperviousness between the $10^{\text {th }}$ and $90^{\text {th }}$ percentiles of the watershed area. This last quantity captures the homogeneity of the distribution of imperviousness within a watershed. A watershed with a large difference in percentages of imperviousness between these two percentiles has a wide range of urbanization within its domain. A watershed with a small difference is fairly uniform in degree of urbanization.

Density Distribution: Urban discharges are a power function of rural discharges, population density, and the difference in population density between the $10^{\text {th }}$ and $90^{\text {th }}$ percentiles of a watershed area. This last quantity captures the homogeneity of the distribution of population density within a watershed. A watershed with a large difference in population density between these 
two percentiles has a wide range of urbanization within its domain. A watershed with a small difference is fairly uniform in degree of urbanization.

Scaled Imperviousness: Urban discharges are a power function of rural discharges and scaled imperviousness. This model assumes a nonlinear effect of imperviousness such that the marginal effect of increasing imperviousness is greatest close to the value $I_{T}^{*}$.

Scaled Density: Urban discharges are a power function of rural discharges and scaled population density. This model assumes a nonlinear effect of population density such that the marginal effect of increasing population density is greatest close to the value $P D_{T}^{*}$.

Sauer (null): Analogous to the "null" model described above, urban discharges are a power function of rural discharges for the dataset assembled by Sauer and others (1983).

\section{Acknowledgements}

The senior author conducted much of the research presented in this report during 2003-04 while on sabbatical at the USGS in Reston, Virginia. The author thanks the USGS for financial support during this sabbatical. The investigative study summarized in this report benefited from many helpful discussions with current and former USGS personnel, including Steve Blanchard, Timothy A. Cohn, Kate Flynn, John R. Gray, William H. Kirby, Harry F. Lins, and Will Thomas. We are especially thankful for the insightful technical reviews provided by Kenneth Eng and William H. Kirby, the thorough editorial reivews performed by Becky Deckard and Sandy Cooper, and the careful documentation preparation of Annette Ledford.

\section{References}

Andersen, D.G., 1970, Effects of urban development of floods in northern Virginia: U.S. Geological Survey Water-Supply Paper 2001-C, 26 p.

Anderson, J.R., Hardy, E.E., Roach, J.T., and Witmer, R.E., 1976, A land use and land cover classification system for use with remote sensor data: U.S. Geological Survey Professional Paper 964, 28 p.

Arnold, C.L, and Gibbons, C.J., 1996, Impervious surface coverage: the emergence of a key environmental indicator: Journal of the American Planning Association, v.62(2), p. 243-258.

Bisese, J.A., 1995, Methods for estimating the magnitude and frequency of peak discharges of rural, unregulated streams in Virginia: U.S. Geological Survey Water-Resources Investigations Report 94-4148, 70 p.

Capiella, K., 2001, Land use/impervious cover relationships in the Chesapeake Bay: Watershed Protection Techniques, v. 3(4), p. $835-840$.

Capiella, K. and Brown, K., 2001, Impervious cover and land use in the Chesapeake Bay watershed: Ellicott City, MD, Center for Watershed Protection, $61 \mathrm{p}$.

Carter, W.R., 1961, Magnitude and frequency of floods in suburban areas: U.S. Geological Survey Professional Paper 424-B, p. 9-11.

Conger, D.H., 1986, Estimating magnitude and frequency of floods for Wisconsin urban streams: U.S. Geological Survey Water-Resources Investigations Report 86-4005, 18 p.

Dillow, J.J.A., 1996, Technique for estimating magnitude and frequency of peak flows in Maryland: U.S. Geological Survey Water-Resources Investigations Report 95-4154, 55 p.

Flynn, K.M., Kirby, W.H. and Hummel, P.R., 2005, User's manual for program PeakFQ, annual flood frequency analysis using Bulletin 17B guidelines: U.S. Geological Survey Water Resources Applications Software; accessed in October 2005 at $h t t p: / /$ water.usgs.gov/software/peakfq.html. 
GeoLytics, Inc., 2003, Neighborhood Change Database (NCDB), 1970-2000 tract data, East Brunswick, NJ, GeoLytics, Inc.; accessed in November 2005 at http://www.geolytics.com/USCensus,Neighborhood-Change-Database-1970-2000,Products. asp.

Homer, C., Huang, C., Yang, L., Wylie, B., and Coan, M., 2004, Development of a 2001 national land-cover database for the United States: Photogrammetric Engineering and Remote Sensing, v. 70, no. 7 [July 2004], p. 829-840.

Interagency Advisory Committee on Water Data, 1982, Guidelines for determining flood flow frequency, Bulletin 17B of the Hydrology Committee: Reston, VA, U.S. Department of the Interior Geological Survey, Office of Water Data Coordination.

James, L.D., 1965, Using a digital computer to estimate the effects of urban development on flood peaks: Water Resources Research, v. 1(2), p. 223-234.

Jennings, M.E., Thomas, W.O., Jr., and Riggs, H.C., 1994, Nationwide summary of U.S. Geological Survey regional regression equations for estimating magnitude and frequency of floods for ungaged sites, 1993: U.S. Geological Survey WaterResources Investigations Report 94-4002, 196 p.

Jenson, S.K. and Domingue, J.O., 1988, Extracting topographic structure from digital elevation data for geographic information system analysis: Photogrammetric Engineering and Remote Sensing, v. 54, no. 11 [November 1988], p. 1593-1600.

Leopold, L.B., 1968, Hydrology for urban land planning: A guidebook on the hydrologic effects of land use: U.S. Geological Survey Circular 554, 18 p.

McCuen, R.H., 1993, Microcomputer applications in statistical hydrology: Prentice-Hall, Englewood Cliffs, NJ, 306 p.

Multi-Resolution Land Characteristics Consortium, 2005, National Land Cover Database, 2001 (NLCD 2001): accessed in January 2006 at http://www.mrlc.gov/mrlc2k_nlcd.asp.

Ries, K.G., III, and Crouse, M.Y., comps. 2002, The National Flood-Frequency Program, Version 3: A computer program for estimating magnitude and frequency of floods for ungaged sites, 2002: U.S. Geological Survey Water-Resources Investigations Report 02-4168, 42 p.

Sauer, V.B., 1973, Flood characteristics of Oklahoma streams; techniques for calculating magnitude and frequency of floods in Oklahoma with compilations of flood data through 1971: U.S. Geological Survey Water-Resources Investigations, 52-73, $301 \mathrm{p}$.

Sauer, V.B., Thomas, W.O., Jr., Stricker, V.A., and Wilson, K.V., 1983, Flood characteristics of urban watersheds in the United States: U.S. Geological Survey Water-Supply Paper 2207, 63 p.

Schueler, T.R., 1987, The importance of imperviousness [1(3)], in Schueler, T.R., and Holland, H.K., eds., 2000, The practice of watershed protection [150-article anthology]: Ellicott City, MD, Center for Watershed Protection, p. 100-111.

Stankowski, S.J., 1972, Population density as an indirect indicator of urban and suburban land-surface modifications: U.S. Geological Survey Professional Paper 800-B, p. 219-224.

Stankowski, S.J., 1974, Magnitude and frequency of floods in New Jersey with effects of urbanization: New Jersey Department of Environmental Protection, Division of Water Resources, Special Report 38, 46 p.

Stuckey, M.H., and Reed, L.A., 2000, Techniques for estimating magnitude and frequency of peak flows for Pennsylvania streams: U.S. Geological Survey Water-Resources Investigations Report 00-4189, 43 p.

U.S. Environmental Protection Agency, 2001, Multi-Resolution Land Characteristics; accessed in August 2005 at http://www. epa.gov/mrlc.

U.S. Geological Survey, 2004a, National Elevation Dataset; accessed in July 2004 at http://ned.usgs.gov/.

U.S. Geological Survey, 2004b, USGS water data for the Nation; accessed in September 2004 at http://waterdata.usgs.gov/nwis/.

U.S. Geological Survey, 2005, National Land Cover Dataset 1992 (NLCD 1992); accessed in December 2005 at http:// landcover.usgs.gov/natlandcover.php.

U.S. Geological Survey and U.S. Environmental Protection Agency, 2004, National hydrography dataset; accessed in July 2004 at http://nhd.usgs.gov/. 
Viessman, W., Jr., 1966, The hydrology of small impervious areas: Water Resources Research. v. 2(3), p. 405-412.

Vogelmann, J.E., Sohl, T., and Howard, S.M., 1998a, Regional characterization of land cover using multiple sources of data: Photogrammetric Engineering and Remote Sensing, v. 64, p. 45-57.

Vogelmann, J.E., Sohl, T., Howard, S.M., and Shaw, D.M., 1998b, Regional land cover characterization using Landsat thematic mapper data and ancillary data sources: Environmental Monitoring and Assessment, v. 51, p. 415-428.

Walker, J.F., and Krug, W.R., 2003, Flood-frequency characteristics of Wisconsin streams: U.S. Geological Survey WaterResources Investigations Report 03-4250, accessed in September 2004 at http://pubs.usgs.gov/wri/wri034250/. 


\section{Methods for Adjusting USGS Rural Regression Peak Discharges in an Urban Setting}

\section{Appendix 1}

\section{Appendix 1: Watershed characteristics of streamgages with only rural indicators.}

[dd, decimal degrees; $\mathrm{mi}^{2}$, square miles; $\mathrm{ft} / \mathrm{mi}$, feet per mile; $\mathrm{ft}$, feet; thousand $\mathrm{ft}$, thousands of feet; $\%$, percent; $\mathrm{mi}^{2} / \mathrm{mi}^{2}$, square miles per square mile]

\begin{tabular}{|c|c|c|c|c|c|c|c|c|c|}
\hline $\begin{array}{c}\text { Streamgage } \\
\text { number }\end{array}$ & Streamgage name & State & Hydrologic region & $\begin{array}{c}\text { 2-year, } \\
\text { 24-hour } \\
\text { rainfall } \\
\text { (inch) }\end{array}$ & $\begin{array}{c}\text { Mean } \\
\text { annual } \\
\text { precipi- } \\
\text { tation } \\
\text { (inch) }\end{array}$ & $\begin{array}{l}\text { Latitude } \\
\text { (dd) }\end{array}$ & $\begin{array}{l}\text { Area } \\
\left(\mathrm{mi}^{2}\right)\end{array}$ & $\begin{array}{c}\text { Contribut- } \\
\text { ing area } \\
\left(\mathrm{mi}^{2}\right)\end{array}$ & $\begin{array}{l}\text { Slope } \\
\text { (ft/mi) }\end{array}$ \\
\hline 11023330 & LOS PENASQUITOS C BL POWAY C NR POWAY & $\mathrm{CA}$ & South Coast & & 14 & & 31.2767 & & \\
\hline 11023340 & LOS PENASQUITOS C NR POWAY & $\mathrm{CA}$ & South Coast & & 13.5 & & 42.3671 & & \\
\hline 11075800 & SANTIAGO C AT MODJESKA & $\mathrm{CA}$ & South Coast & & 23 & & 13.0287 & & \\
\hline 11162720 & COLMA C AT S SAN FRANCISCO & $\mathrm{CA}$ & Central Coast & & 22.5 & & 10.8595 & & \\
\hline 11162800 & REDWOOD C AT REDWOOD CITY & $\mathrm{CA}$ & Central Coast & & 25 & & 1.68449 & & \\
\hline 11166000 & MATADERO C AT PALO ALTO & $\mathrm{CA}$ & Central Coast & & 20 & & 7.05069 & & \\
\hline 11183600 & WALNUT C AT CONCORD & $\mathrm{CA}$ & Central Coast & & 23 & & 84.1331 & & \\
\hline 11336580 & MORRISON C NR SACRAMENTO & $\mathrm{CA}$ & Central Coast & & 18.5 & & 46.8109 & & \\
\hline 02231280 & THOMAS C NR CRAWFORD & FL & Region A & & & & 34.9028 & & 15.7775 \\
\hline 02246300 & ORTEGA R AT JACKSONVILLE & FL & Region A & & & & 28.1 & & 12.9732 \\
\hline 02246828 & PABLO C AT JACKSONVILLE & FL & Region A & & & & 22.6575 & & 15.0657 \\
\hline 03337000 & BONEYARD C AT URBANA & $\mathrm{IL}$ & Region 1 & 3 & & & 4.20883 & & 37.931 \\
\hline 05528500 & BUFFALO C NR WHEELING & $\mathrm{IL}$ & Region $1 \& 2$ & 2.7 & & & 23.8388 & & 19.8662 \\
\hline 05529500 & MC DONALD C NR MT PROSPECT & $\mathrm{IL}$ & Region 1 & 2.7 & & & 8.47548 & & 21.7277 \\
\hline 05530000 & WELLER C AT DES PLAINES & $\mathrm{IL}$ & Region 1 & 2.7 & & & 12.8585 & & 19.2446 \\
\hline 05531500 & SALT C AT WESTERN SPRINGS & $\mathrm{IL}$ & Region 1 & 2.7 & & & 114.996 & & 6.41933 \\
\hline 05532000 & ADDISON C AT BELLWOOD & IL & Region 1 & 2.7 & & & 16.3686 & & 17.4477 \\
\hline 05533000 & FLAG C NR WILLOW SPRINGS & IL & Region 1 & 2.7 & & & 16.8802 & & 19.2316 \\
\hline 05533400 & SAWMILL C NR LEMONT & $\mathrm{IL}$ & Region 1 & 2.75 & & & 12.1458 & & 27.5769 \\
\hline 05534500 & NB CHICAGO R AT DEERFIELD & $\mathrm{IL}$ & Region 1 & 2.7 & & & 19.6466 & & 10.7933 \\
\hline 05535000 & SKOKIE R AT LAKE FOREST & $\mathrm{IL}$ & Region 1 & 2.7 & & & 12.7473 & & 14.6833 \\
\hline 05535500 & WF OF NB CHICAGO R AT NORTHBROOK & IL & Region 1 & 2.7 & & & 11.6297 & & 17.5063 \\
\hline 05536000 & NB CHICAGO R AT NILES & $\mathrm{IL}$ & Region 1 & 2.7 & & & 99.2577 & & 5.79078 \\
\hline 05536215 & THORN C AT GLENWOOD & $\mathrm{IL}$ & Region 1 & 2.8 & & & 18.2409 & & 18.583 \\
\hline 05536255 & BUTTERFIELD C AT FLOSSMOOR & IL & Region 1 & 2.8 & & & 23.3021 & & 12.023 \\
\hline 05536275 & THORN C AT THORNTON & $\mathrm{IL}$ & Region 1 & 2.8 & & & 102.905 & & 10.0069 \\
\hline 05536340 & MIDLOTHIAN C AT OAK FOREST & $\mathrm{IL}$ & Region 1 & 2.8 & & & 12.8987 & & 18.1147 \\
\hline 05536500 & TINLEY C NR PALOS PARK & IL & Region 1 & 2.75 & & & 11.2544 & & 21.7328 \\
\hline 05539900 & WB DU PAGE R NR W CHICAGO & $\mathrm{IL}$ & Region 2 & 2.75 & & & 29.629 & & 12.3176 \\
\hline 05540060 & KRESS C AT W CHICAGO & $\mathrm{IL}$ & Region 2 & 2.8 & & & 19.9741 & & 17.5559 \\
\hline 05540160 & E BR DU PAGE R NR DOWNERS GROVE & $\mathrm{IL}$ & Region 1 & 2.75 & & & 25.3031 & & 16.0058 \\
\hline 05540500 & DU PAGE R AT SHOREWOOD & IL & Region 2 & 2.8 & & & 328.971 & & 4.45675 \\
\hline 05550500 & POPLAR C AT ELGIN & IL & Region 2 & 2.75 & & & 34.625 & & 13.7089 \\
\hline 01097300 & NASHOBA BROOK NR ACTON & MA & Eastern & & & & 11.3877 & & 32.5419 \\
\hline 01105600 & OLD SWAMP R NR S WEYMOUTH & MA & Eastern & & & & 4.83577 & & 34.5835 \\
\hline 01581700 & WINTERS RUN NR BENSON & MD & Piedmont & & & & & 34.7 & \\
\hline 01583500 & WESTERN RUN AT WESTERN RUN & MD & Piedmont & & & & & 60.3 & \\
\hline 01584050 & LONG GREEN C AT GLEN ARM & MD & Piedmont & & & & & 9.3 & \\
\hline 01584500 & $\begin{array}{l}\text { LITTLE GUNPOWDER FALLS AT LAUREL } \\
\text { BROOK }\end{array}$ & MD & Piedmont & & & & & 36.1 & \\
\hline
\end{tabular}




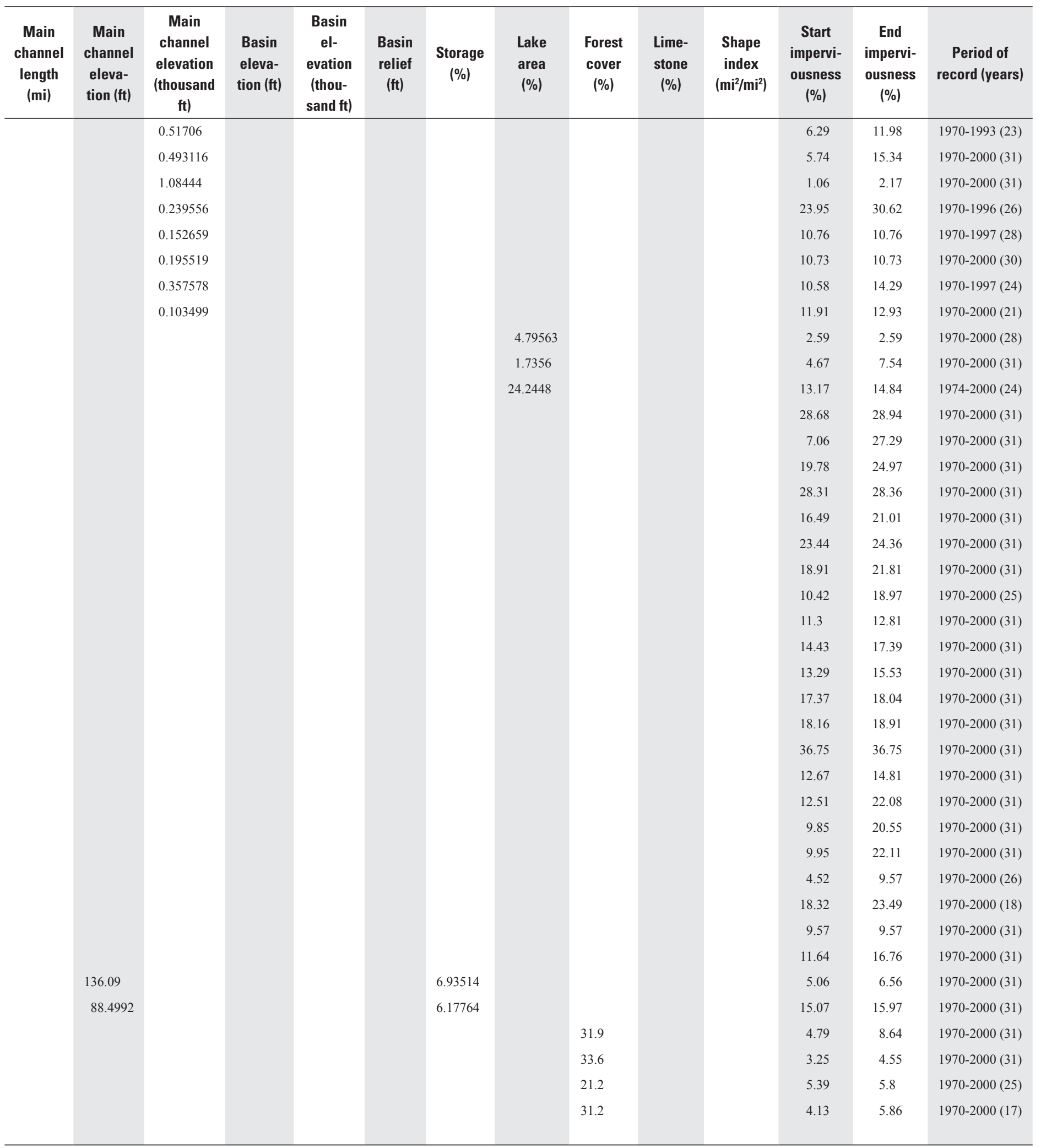


Appendix 1: Watershed characteristics of streamgages with only rural indicators-continued.

[dd, decimal degrees; $\mathrm{mi}^{2}$, square miles; $\mathrm{ft} / \mathrm{mi}$, feet per mile; $\mathrm{ft}$, feet; thousand $\mathrm{ft}$, thousands of feet; $\%$, percent; $\mathrm{mi}^{2} / \mathrm{mi}^{2}$, square miles per square mile]

\begin{tabular}{|c|c|c|c|c|c|c|c|c|c|}
\hline $\begin{array}{l}\text { Streamgage } \\
\text { number }\end{array}$ & Streamgage name & State & Hydrologic region & $\begin{array}{l}\text { 2-year, } \\
\text { 24-hour } \\
\text { rainfall } \\
\text { (inch) }\end{array}$ & $\begin{array}{c}\text { Mean } \\
\text { annual } \\
\text { precipi- } \\
\text { tation } \\
\text { (inch) }\end{array}$ & $\begin{array}{l}\text { Latitude } \\
\text { (dd) }\end{array}$ & $\begin{array}{l}\text { Area } \\
\left(\mathrm{mi}^{2}\right)\end{array}$ & $\begin{array}{c}\text { Contribut- } \\
\text { ing area } \\
\left(\mathrm{mi}^{2}\right)\end{array}$ & $\begin{array}{l}\text { Slope } \\
\text { (ft/mi) }\end{array}$ \\
\hline 01585100 & WHITEMARSH RUN AT WHITE MARSH & MD & Western Coastal Plain & & & & & 7.6 & \\
\hline 01585200 & W B HERRING RUN AT IDLEWYLDE & MD & Piedmont & & & & & 2.2 & \\
\hline 01585500 & CRANBERRY B NR WESTMINSTER & MD & Piedmont & & & & & 3.4 & \\
\hline 01586000 & N B PATAPSCO R AT CEDARHURST & MD & Piedmont & & & & & 56.3 & \\
\hline 01589100 & E B HERBERT RUN AT ARBUTUS & MD & Western Coastal Plain & & & & & 2.4 & \\
\hline 01589300 & GWYNNS FALLS AT VILLA NOVA & MD & Piedmont & & & & & 32.6 & \\
\hline 01589330 & DEAD RUN AT FRANKLINTOWN & MD & Piedmont & & & & & 5.6 & \\
\hline 01589440 & JONES FALLS AT SORRENTO & MD & Piedmont & & & & & 25.2 & \\
\hline 01590500 & BACON RIDGE B AT CHESTERFIELD & MD & Western Coastal Plain & & & & & 6.9 & \\
\hline 01591000 & PATUXENT R NR UNITY & MD & Piedmont & & & & & 34.8 & \\
\hline 01591400 & CATTAIL C NR GLENWOOD & MD & Piedmont & & & & & 22.9 & \\
\hline 01591700 & HAWLINGS R NR SANDY SPRING & MD & Piedmont & & & & & 26.2 & \\
\hline 01639500 & BIG PIPE C AT BRUCEVILLE & MD & $\begin{array}{l}\text { Blue Ridge and Great } \\
\text { Valley }\end{array}$ & & & & & 102.8 & \\
\hline 01645000 & SENECA C AT DAWSONVILLE & MD & $\begin{array}{l}\text { Blue Ridge and Great } \\
\text { Valley }\end{array}$ & & & & & 102 & \\
\hline 01649500 & NE B ANACOSTIA R AT RIVERDALE & MD & Western Coastal Plain & & & & & 73.1 & \\
\hline 01651000 & NW B ANACOSTIA R NEAR HYATTSVILLE & MD & Western Coastal Plain & & & & & 49.3 & \\
\hline 01653600 & PISCATAWAY C AT PISCATAWAY & MD & Western Coastal Plain & & & & & 38.6 & \\
\hline 02485650 & PURPLE C AT JACKSON & MS & East & & & & 6.11212 & & 27.858 \\
\hline 02485700 & HANGING MOSS C NR JACKSON & MS & East & & & & 17.1624 & & 22.3212 \\
\hline 02485950 & TOWN C AT JACKSON & MS & East & & & & 9.49435 & & 26.0154 \\
\hline 02486100 & LYNCH C AT JACKSON & MS & East & & & & 11.9325 & & 28.9894 \\
\hline 09419663 & $\begin{array}{l}\text { LAS VEGAS WASH TR S OF NELLIS AIR FORCE } \\
\text { BASE }\end{array}$ & $\mathrm{NV}$ & Region 10 & & & 36.19444 & 1.04392 & 1.04392 & \\
\hline 09419670 & RED ROCK WASH NR BLUE DIAMOND & NV & Region 10 & & & 36.15833 & 8.04635 & 8.04635 & \\
\hline 10311200 & ASH CANYON C NR CARSON CITY & NV & Region 5 & & & 39.17639 & 5.38204 & 5.38204 & \\
\hline 01376500 & SAW MILL R AT YONKERS & NY & Region 3 & & 48 & & 25.2228 & & 15.8832 \\
\hline 04214500 & BUFFALO C AT GARDENVILLE & NY & Region 6 & & 38 & & 142.638 & & 10.6801 \\
\hline 04215500 & CAZENOVIA C AT EBENEZER & NY & Region 6 & & 39 & & 135.705 & & 16.0498 \\
\hline 04218518 & ELLICOTT C BELOW WILLIAMSVILLE & NY & Region 6 & & 35 & & 80.5685 & & 11.4892 \\
\hline 04240010 & ONONDAGA C AT SPENCER ST, SYRACUSE & NY & Region 7 & & 37 & & 127.722 & & 27.3073 \\
\hline 04240100 & HARBOR BROOK AT SYRACUSE & NY & Region 7 & & 37 & & 10.0487 & & 71.1392 \\
\hline 01114000 & MOSHASSUCK R AT PROVIDENCE & RI & - & & & & 15.5125 & & \\
\hline 01117000 & HUNT R NR E GREENWICH & RI & - & & & & 23.0741 & & \\
\hline 01652500 & FOURMILE RUN AT ALEXANDRIA & VA & Northern Piedmont & & & & 14.0295 & 14.0295 & 37.1694 \\
\hline 01653000 & CAMERON RUN AT ALEXANDRIA & VA & Northern Piedmont & & & & 33.9277 & 18.7489 & 25.8906 \\
\hline 01654000 & ACCOTINK C NR ANNANDALE & VA & Northern Piedmont & & & & 23.8425 & 0.781281 & 22.5089 \\
\hline 02037800 & FALLING C NR MIDLOTHIAN & VA & Southern Piedmont & & & & 18.7191 & 13.768 & 22.3087 \\
\hline 02038000 & FALLING C NR CHESTERFIELD & VA & Southern Piedmont & & & & 33.8736 & 6.35192 & 15.65 \\
\hline 03052500 & SAND RUN NR BUCKHANNON & WV & North Region & & & & 14.3806 & & \\
\hline 03062400 & COBUN CREEK AT MORGANTOWN & WV & North Region & & & & 10.9832 & & \\
\hline
\end{tabular}




\begin{tabular}{|c|c|c|c|c|c|c|c|c|c|c|c|c|c|}
\hline $\begin{array}{l}\text { Main } \\
\text { channel } \\
\text { length } \\
\text { (mi) }\end{array}$ & $\begin{array}{c}\text { Main } \\
\text { channel } \\
\text { eleva- } \\
\text { tion (ft) }\end{array}$ & $\begin{array}{c}\text { Main } \\
\text { channel } \\
\text { elevation } \\
\text { (thousand } \\
\text { ft) }\end{array}$ & $\begin{array}{l}\text { Basin } \\
\text { eleva- } \\
\text { tion (ft) }\end{array}$ & $\begin{array}{l}\text { Basin } \\
\text { el- } \\
\text { evation } \\
\text { (thou- } \\
\text { sand ft) }\end{array}$ & $\begin{array}{c}\text { Basin } \\
\text { relief } \\
\text { (ft) }\end{array}$ & $\begin{array}{c}\text { Storage } \\
(\%)\end{array}$ & $\begin{array}{c}\text { Lake } \\
\text { area } \\
(\%)\end{array}$ & $\begin{array}{c}\text { Forest } \\
\text { cover } \\
(\%)\end{array}$ & $\begin{array}{c}\text { Lime- } \\
\text { stone } \\
(\%)\end{array}$ & $\begin{array}{c}\text { Shape } \\
\text { index } \\
\left(\mathrm{mi}^{2} / \mathrm{mi}^{2}\right)\end{array}$ & $\begin{array}{c}\text { Start } \\
\text { impervi- } \\
\text { ousness } \\
(\%)\end{array}$ & $\begin{array}{c}\text { End } \\
\text { impervi- } \\
\text { ousness } \\
(\%)\end{array}$ & $\begin{array}{c}\text { Period of } \\
\text { record (years) }\end{array}$ \\
\hline & & & & & & & & 12.7 & & & 13.58 & 23.82 & $1970-2000(29)$ \\
\hline & & & & & & & & 15.5 & & & 30.06 & 30.06 & $1970-2000(20)$ \\
\hline & & & & & & & & 23 & & & 4.1 & 7.09 & $1970-2000(31)$ \\
\hline & & & & & & & & 25.9 & & & 4.78 & 6.98 & $1970-2000(31)$ \\
\hline & & & & & & & & 8.3 & & & 26.52 & 26.79 & $1970-2000(22)$ \\
\hline & & & & & & & & 24.3 & & & 15.29 & 20.51 & $1970-2000(23)$ \\
\hline & & & & & & & & 5 & & & 16.88 & 21.57 & $1970-2000(20)$ \\
\hline & & & & & & & & 46.5 & & & 7.64 & 11.09 & $1970-2000(23)$ \\
\hline & & & & & & & & 52.8 & & & 7.93 & 7.93 & 1970-1990 (21) \\
\hline & & & & & & & & 38.2 & & & 3.52 & 5.38 & $1970-2000(31)$ \\
\hline & & & & & & & & 17.9 & & & 3.65 & 4.99 & $1979-2000(22)$ \\
\hline & & & & & & & & 26.7 & & & 6.22 & 8.37 & 1979-2000 (22) \\
\hline & & & & & 292.6 & & & & 0 & & 3.54 & 5.06 & $1970-2000(31)$ \\
\hline & & & & & 253.8 & & & & 0 & & 4.8 & 12.89 & $1970-2000(31)$ \\
\hline & & & & & & & & 28.4 & & & 15.84 & 18.48 & $1970-2000(31)$ \\
\hline & & & & & & & & 20.8 & & & 22.2 & 24.96 & $1970-2000(31)$ \\
\hline & & & & & & & & 49.9 & & & 7.15 & 10.23 & $1970-2000(31)$ \\
\hline 7.32016 & & & & & & & & & & & 10.71 & 12.13 & $1970-2000(28)$ \\
\hline 8.14158 & & & & & & & & & & & 9.79 & 10.75 & $1970-2000(31)$ \\
\hline 6.89985 & & & & & & & & & & & 20.63 & 20.91 & $1970-2000(27)$ \\
\hline \multirow[t]{12}{*}{6.70905} & & & & & & & & & & & 16.39 & 17.54 & $1970-2000(29)$ \\
\hline & & & 883.491 & & & & & & & & 0.46 & 5.53 & $1970-1998(28)$ \\
\hline & & & 1936.4 & & & & & & & & 0.37 & 0.64 & 1970-1999 (30) \\
\hline & & & 2312.27 & & & & & & & & 1.74 & 2.89 & $1977-2000(23)$ \\
\hline & 162.236 & & & & & 0.711219 & & 35.7406 & & 21.1296 & 19.01 & 19.89 & $1970-1999(24)$ \\
\hline & 288.828 & & & & & 0.879581 & & 42.0923 & & 13.356 & 3.99 & 5.37 & $1970-2000(31)$ \\
\hline & 424.913 & & & & & 0.507045 & & 56.7619 & & 11.9188 & 5.03 & 5.2 & $1970-2000(31)$ \\
\hline & 356.182 & & & & & 1.21751 & & 33.944 & & 20.8887 & 8.5 & 8.5 & $1973-2000(28)$ \\
\hline & 393.303 & & & & & 0.762828 & & 51.5949 & & 5.96086 & 8.22 & 8.22 & $1971-2000(30)$ \\
\hline & 310.797 & & & & & 0.296921 & & 35.3556 & & 5.02514 & 11.9 & 12.24 & $1970-2000(31)$ \\
\hline & & & & 0.152314 & & & & 29.8198 & & & 22.88 & 24.31 & $1970-2000(31)$ \\
\hline & & & & 0.154381 & & & & 62.5405 & & & 8.07 & 8.88 & $1970-2000(31)$ \\
\hline 8.22381 & 122.926 & & & & & & & 20.4007 & & & 33.81 & 37.05 & $1970-2000(30)$ \\
\hline 12.1626 & 129.507 & & & & & & & 32.3356 & & & 19.85 & 19.85 & $1970-2000(31)$ \\
\hline 11.1018 & 153.17 & & & & & & & 38.1093 & & & 20.53 & 24.51 & $1970-2000(30)$ \\
\hline 9.67723 & 133.053 & & & & & & & 61.0473 & & & 3.7 & 13.32 & $1970-1993(23)$ \\
\hline \multirow[t]{3}{*}{14.5847} & 128.416 & & & & & & & 61.2425 & & & 4.64 & 13.87 & $1970-2000(29)$ \\
\hline & & & & & & & & & & & 0 & 2.07 & $1970-2000(31)$ \\
\hline & & & & & & & & & & & 0 & 5.95 & $1970-2000(31)$ \\
\hline
\end{tabular}


Appendix 2

Appendix 2: Actual and estimated rural discharges for streamgages with only rural indicators.

[ft $3 / \mathrm{s}$, cubic feet per second; italics, numbers in italics satisfy equation 19 and indicate their use in the regression equation analyses in this study]

\begin{tabular}{|c|c|c|c|c|c|}
\hline $\begin{array}{c}\text { Streamgage } \\
\text { number }\end{array}$ & Streamgage name & $\begin{array}{c}\text { 2-year } \\
\text { actual } \\
\left(\mathrm{ft}^{3} / \mathrm{s}\right)\end{array}$ & $\begin{array}{c}\text { 2-year } \\
\text { rural } \\
\left(\mathrm{ft}^{3} / \mathrm{s}\right)\end{array}$ & $\begin{array}{c}\text { 5-year } \\
\text { actual } \\
\left(\mathrm{ft}^{3} / \mathrm{s}\right)\end{array}$ & $\begin{array}{c}\text { 5-year } \\
\text { rural } \\
\left(\mathrm{ft}^{3} / \mathrm{s}\right)\end{array}$ \\
\hline 11023330 & LOS PENASQUITOS C BL POWAY C NR POWAY & 775 & 120 & 1757 & 490 \\
\hline 11023340 & LOS PENASQUITOS C NR POWAY & 1027 & 141 & 2352 & 582 \\
\hline 11075800 & SANTIAGO C AT MODJESKA & 338 & 143 & 1188 & 578 \\
\hline 11162720 & COLMA C AT S SAN FRANCISCO & 1775 & 717 & 2524 & 1385 \\
\hline 11162800 & REDWOOD C AT REDWOOD CITY & 218 & 277 & 348 & 445 \\
\hline 11166000 & MATADERO C AT PALO ALTO & 400 & 447 & 746 & 872 \\
\hline 11183600 & WALNUT C AT CONCORD & 4005 & 3209 & 7874 & 6789 \\
\hline 11336580 & MORRISON C NR SACRAMENTO & 1115 & 4170 & 1809 & 6871 \\
\hline 02231280 & THOMAS C NR CRAWFORD & 594 & 552 & 1095 & 1061 \\
\hline 02246300 & ORTEGA R AT JACKSONVILLE & 802 & 663 & 1421 & 1260 \\
\hline 02246828 & PABLO C AT JACKSONVILLE & 418 & 144 & 647 & 297 \\
\hline 03337000 & BONEYARD C AT URBANA & 644 & 451 & 814 & 805 \\
\hline 05528500 & BUFFALO C NEAR WHEELING & 447 & 540 & 602 & 904 \\
\hline 05529500 & MC DONALD C NEAR MOUNT PROSPECT & 237 & 322 & 380 & 543 \\
\hline 05530000 & WELLER C AT DES PLAINES & 892 & 422 & 1105 & 708 \\
\hline 05531500 & SALT C AT WESTERN SPRINGS & 1425 & 1407 & 1873 & 2255 \\
\hline 05532000 & ADDISON C AT BELLWOOD & 505 & 488 & 666 & 814 \\
\hline 05533000 & FLAG C NR WILLOW SPRINGS & 779 & 524 & 1085 & 876 \\
\hline 05533400 & SAWMILL C NR LEMONT & 707 & 558 & 1075 & 956 \\
\hline 05534500 & NB CHICAGO R AT DEERFIELD & 417 & 447 & 583 & 734 \\
\hline 05535000 & SKOKIE RIVER AT LAKE FOREST & 277 & 368 & 377 & 612 \\
\hline 05535500 & WF OF NB CHICAGO R AT NORTHBROOK & 542 & 373 & 712 & 623 \\
\hline 05536000 & NB CHICAGO R AT NILES & 1270 & 1192 & 1632 & 1905 \\
\hline 05536215 & THORN C AT GLENWOOD & 1275 & 721 & 1752 & 1225 \\
\hline 05536255 & BUTTERFIELD C AT FLOSSMOOR & 801 & 709 & 1254 & 1188 \\
\hline 05536275 & THORN C AT THORNTON & 2024 & 2099 & 2884 & 3473 \\
\hline 05536340 & MIDLOTHIAN C AT OAK FOREST & 232 & 541 & 323 & 921 \\
\hline 05536500 & TINLEY C NR PALOS PARK & 661 & 469 & 969 & 796 \\
\hline 05539900 & WB DU PAGE R NR WEST CHICAGO & 559 & 419 & 721 & 697 \\
\hline 05540060 & KRESS CREEK AT WEST CHICAGO & 289 & 412 & 398 & 699 \\
\hline 05540160 & E BR DU PAGE R NR DOWNERS GROVE & 612 & 768 & 863 & 1287 \\
\hline 05540500 & DU PAGE R AT SHOREWOOD & 3697 & 1948 & 4965 & 3128 \\
\hline 05550500 & POPLAR C AT ELGIN & 539 & 499 & 735 & 832 \\
\hline 01097300 & NASHOBA BROOK NR ACTON & 202 & 191 & 329 & 283 \\
\hline 01105600 & OLD SWAMP R NR S WEYMOUTH & 161 & 106 & 249 & 159 \\
\hline 01581700 & WINTERS RUN NR BENSON & 2610 & 1590 & 4792 & 2850 \\
\hline 01583500 & WESTERN RUN AT WESTERN RUN & 2332 & 2230 & 4260 & 3940 \\
\hline 01584050 & LONG GREEN C AT GLEN ARM & 695 & 743 & 1475 & 1380 \\
\hline
\end{tabular}




\begin{tabular}{|c|c|c|c|c|c|c|c|c|c|}
\hline $\begin{array}{c}10 \text {-year } \\
\text { actual } \\
\left(\mathrm{ft}^{3} / \mathrm{s}\right)\end{array}$ & $\begin{array}{c}\text { 10-year } \\
\text { rural } \\
\left(\mathrm{ft}^{3} / \mathrm{s}\right)\end{array}$ & $\begin{array}{c}\text { 25-year } \\
\text { actual } \\
\left(\mathrm{ft}^{3} / \mathrm{s}\right)\end{array}$ & $\begin{array}{c}\text { 25-year } \\
\text { rural } \\
\left(\mathrm{ft}^{3} / \mathrm{s}\right)\end{array}$ & $\begin{array}{c}\text { 50-year } \\
\text { actual } \\
\left(\mathrm{ft}^{3} / \mathrm{s}\right)\end{array}$ & $\begin{array}{c}\text { 50-year } \\
\text { rural } \\
\left(\mathrm{ft}^{3} / \mathrm{s}\right)\end{array}$ & $\begin{array}{c}100 \text {-year } \\
\text { actual } \\
\left(\mathrm{ft}^{3} / \mathrm{s}\right)\end{array}$ & $\begin{array}{c}100 \text {-year } \\
\text { rural } \\
\left(\mathrm{ft}^{3} / \mathrm{s}\right)\end{array}$ & $\begin{array}{c}\text { 500-year } \\
\text { actual } \\
\left(\mathrm{ft}^{3} / \mathrm{s}\right)\end{array}$ & $\begin{array}{c}\text { 500-year } \\
\text { rural } \\
\left(\mathrm{ft}^{3} / \mathrm{s}\right)\end{array}$ \\
\hline 2639 & 969 & 4008 & 2123 & 5206 & 3331 & 6549 & 4724 & 10260 & 9586 \\
\hline 3587 & 1156 & 5582 & 2542 & 7393 & 3994 & 9493 & 5678 & 15610 & 11575 \\
\hline 2116 & 1156 & 3700 & 2566 & 5151 & 4069 & 6802 & 5779 & 11310 & 11754 \\
\hline 2980 & 1871 & 3511 & 2511 & 3877 & 3040 & 4219 & 3521 & 4945 & 4738 \\
\hline 423 & 553 & 504 & 684 & 555 & 776 & 598 & 866 & 678 & 1080 \\
\hline 1018 & 1195 & 1401 & 1631 & 1711 & 1993 & 2040 & 2332 & 2878 & 3205 \\
\hline 10560 & 9470 & 13830 & 13068 & 16120 & 16320 & 18250 & 19040 & 22600 & 26013 \\
\hline 2249 & 8621 & 2766 & 10857 & 3119 & 12750 & 3446 & 14123 & 4120 & 17373 \\
\hline 1553 & 1476 & 2309 & 2082 & 3022 & 2580 & 3884 & 3116 & 6625 & 4428 \\
\hline 1882 & 1742 & 2505 & 2442 & 2992 & 3016 & 3493 & 3633 & 4713 & 5192 \\
\hline 807 & 427 & 1018 & 622 & 1180 & 784 & 1345 & 961 & 1744 & 1392 \\
\hline 906 & 1062 & 1005 & 1395 & 1069 & 1652 & 1126 & 1903 & 1238 & 2502 \\
\hline 700 & 1150 & 820 & 1456 & 908 & 1678 & 994 & 1888 & 1190 & 2367 \\
\hline 494 & 693 & 660 & 880 & 800 & 1017 & 956 & 1146 & 1386 & 1443 \\
\hline 1221 & 901 & 1346 & 1142 & 1427 & 1318 & 1500 & 1483 & 1645 & 1863 \\
\hline 2202 & 2806 & 2655 & 3486 & 3021 & 3961 & 3413 & 4410 & 4442 & 5426 \\
\hline 780 & 1034 & 931 & 1308 & 1049 & 1507 & 1172 & 1695 & 1481 & 2125 \\
\hline 1306 & 1115 & 1605 & 1414 & 1843 & 1631 & 2094 & 1837 & 2738 & 2309 \\
\hline 1329 & 1231 & 1658 & 1581 & 1907 & 1840 & 2160 & 2089 & 2764 & 2666 \\
\hline 692 & 924 & 826 & 1158 & 924 & 1325 & 1020 & 1482 & 1242 & 1839 \\
\hline 437 & 775 & 504 & 977 & 550 & 1123 & 593 & 1260 & 681 & 1573 \\
\hline 830 & 792 & 987 & 1002 & 1110 & 1154 & 1237 & 1298 & 1557 & 1626 \\
\hline 1869 & 2367 & 2168 & 2934 & 2391 & 3328 & 2615 & 3701 & 3146 & 4541 \\
\hline 2072 & 1573 & 2481 & 2013 & 2790 & 2338 & 3101 & 2651 & 3848 & 3377 \\
\hline 1627 & 1512 & 2194 & 1919 & 2693 & 2216 & 3263 & 2499 & 4927 & 3154 \\
\hline 3500 & 4400 & 4333 & 5573 & 4992 & 6418 & 5684 & 7234 & 7449 & 9117 \\
\hline 389 & 1182 & 481 & 1512 & 555 & 1755 & 635 & 1989 & 843 & 2530 \\
\hline 1179 & 1022 & 1450 & 1305 & 1655 & 1515 & 1863 & 1714 & 2360 & 2176 \\
\hline 817 & 880 & 926 & 1108 & 1001 & 1269 & 1072 & 1421 & 1221 & 1765 \\
\hline 474 & 893 & 574 & 1136 & 652 & 1313 & 732 & 1480 & 932 & 1864 \\
\hline 1062 & 1640 & 1354 & 2084 & 1603 & 2408 & 1882 & 2718 & 2669 & 3431 \\
\hline 5649 & 3884 & 6371 & 4821 & 6823 & 5466 & 7215 & 6077 & 7954 & 7457 \\
\hline 853 & 1053 & 989 & 1328 & 1082 & 1524 & 1169 & 1709 & 1354 & 2128 \\
\hline 429 & 359 & 576 & 471 & 701 & 567 & 838 & 676 & 1217 & 963 \\
\hline 308 & 204 & 382 & 270 & 436 & 326 & 490 & 391 & 614 & 564 \\
\hline 6478 & 3970 & 8828 & 5690 & 10710 & 7210 & 12690 & 8970 & 17680 & 14200 \\
\hline 5852 & 5440 & 8227 & 7740 & 10260 & 9760 & 12530 & 12100 & 18810 & 19000 \\
\hline 2207 & 1960 & 3416 & 2870 & 4550 & 3680 & 5903 & 4630 & 10080 & 7490 \\
\hline
\end{tabular}


Appendix 2: Actual and estimated rural discharges for streamgages with only rural indicators—continued.

[ $\mathrm{ft}^{3} / \mathrm{s}$, cubic feet per second; italics, numbers in italics satisfy equation 19 and indicate their use in the regression equation analyses in this study]

\begin{tabular}{|c|c|c|c|c|c|}
\hline $\begin{array}{c}\text { Streamgage } \\
\text { number }\end{array}$ & Streamgage name & $\begin{array}{c}\text { 2-year } \\
\text { actual } \\
\left(\mathrm{ft}^{3} / \mathrm{s}\right)\end{array}$ & $\begin{array}{l}\text { 2-year } \\
\text { rural } \\
\left(\mathrm{ft}^{3} / \mathrm{s}\right)\end{array}$ & $\begin{array}{l}\text { 5-year } \\
\text { actual } \\
\left(\mathrm{ft}^{3} / \mathrm{s}\right)\end{array}$ & $\begin{array}{l}\text { 5-year } \\
\text { rural } \\
\left(\mathrm{ft}^{3} / \mathrm{s}\right)\end{array}$ \\
\hline 01584500 & LITTLE GUNPOWDER FALLS AT LAUREL BROOK & 3856 & 1630 & 6022 & 2930 \\
\hline 01585100 & WHITEMARSH RUN AT WHITE MARSH & 1559 & 625 & 2248 & 1116 \\
\hline 01585200 & WB HERRING RUN AT IDLEWYLDE & 718 & 314 & 1141 & 606 \\
\hline 01585500 & CRANBERRY B NR WESTMINSTER & 380 & 386 & 845 & 740 \\
\hline 01586000 & NB PATAPSCO R AT CEDARHURST & 2685 & 2250 & 4232 & 3960 \\
\hline 01589100 & EB HERBERT RUN AT ARBUTUS & 663 & 329 & 932 & 602 \\
\hline 01589300 & GWYNNS FALLS AT VILLA NOVA & 1940 & 1610 & 3303 & 2880 \\
\hline 01589330 & DEAD RUN AT FRANKLINTOWN & 1587 & 654 & 2336 & 1220 \\
\hline 01589440 & JONES FALLS AT SORRENTO & 1111 & 1190 & 2006 & 2180 \\
\hline 01590500 & BACON RIDGE B AT CHESTERFIELD & 196 & 240 & 311 & 457 \\
\hline 01591000 & PATUXENT R NR UNITY & 1491 & 1530 & 2896 & 2750 \\
\hline 01591400 & CATTAIL C NR GLENWOOD & 2169 & 1360 & 3413 & 2450 \\
\hline 01591700 & HAWLINGS R NR SANDY SPRING & 1329 & 1370 & 2625 & 2480 \\
\hline 01639500 & BIG PIPE C AT BRUCEVILLE & 3318 & 3864 & 5544 & 6874 \\
\hline 01645000 & SENECA C AT DAWSONVILLE & 4031 & 3366 & 7435 & 5876 \\
\hline 01649500 & NE B ANACOSTIA R AT RIVERDALE & 4953 & 2204 & 7121 & 4039 \\
\hline 01651000 & NW B ANACOSTIA R NR HYATTSVILLE & 3645 & 2063 & 5594 & 3670 \\
\hline 01653600 & PISCATAWAY C AT PISCATAWAY & 975 & 922 & 1852 & 1770 \\
\hline 02485650 & PURPLE C AT JACKSON & 1091 & 692 & 1416 & 1168 \\
\hline 02485700 & HANGING MOSS C NR JACKSON & 2771 & 1527 & 3693 & 2638 \\
\hline 02485950 & TOWN C AT JACKSON & 2725 & 1008 & 3288 & 1718 \\
\hline 02486100 & LYNCH C AT JACKSON & 3316 & 1229 & 3883 & 2118 \\
\hline 09419663 & LAS VEGAS WASH TR S OF NELLIS AIR FORCE BASE & 1.40 & 12.0 & 24.3 & 87.0 \\
\hline 09419670 & RED ROCK WASH NR BLUE DIAMOND & 5.40 & 40.0 & 112 & 291 \\
\hline 10311200 & ASH CANYON C NR CARSON CITY & 14.3 & 2.10 & 38.3 & 36.0 \\
\hline 01376500 & SAW MILL R AT YONKERS & 687 & 852 & 965 & 1371 \\
\hline 04214500 & BUFFALO C AT GARDENVILLE & 6251 & 4005 & 7938 & 5747 \\
\hline 04215500 & CAZENOVIA C AT EBENEZER & 7115 & 4541 & 9333 & 6674 \\
\hline 04218518 & ELLICOTT C BELOW WILLIAMSVILLE & 1787 & 2190 & 2347 & 3204 \\
\hline 04240010 & ONONDAGA C AT SPENCER ST, SYRACUSE & 1907 & 6132 & 2643 & 9086 \\
\hline 04240100 & HARBOR BROOK AT SYRACUSE & 227 & 950 & 342 & 1453 \\
\hline 01114000 & MOSHASSUCK R AT PROVIDENCE & 913 & 369 & 1116 & 632 \\
\hline 01117000 & HUNT R NR E GREENWICH & 434 & 334 & 629 & 564 \\
\hline 01652500 & FOURMILE RUN AT ALEXANDRIA & 3048 & 1010 & 3918 & 1737 \\
\hline 01653000 & CAMERON RUN AT ALEXANDRIA & 3908 & 1221 & 5077 & 2093 \\
\hline 01654000 & ACCOTINK C NR ANNANDALE & 2651 & 1429 & 3961 & 2444 \\
\hline 02037800 & FALLING C NR MIDLOTHIAN & 534 & 380 & 852 & 647 \\
\hline 02038000 & FALLING C NR CHESTERFIELD & 830 & 477 & 1374 & 803 \\
\hline 03052500 & SAND RUN NEAR BUCKHANNON & 858 & 951 & 1472 & 1518 \\
\hline 03062400 & COBUN CREEK AT MORGANTOWN & 470 & 782 & 855 & 1264 \\
\hline
\end{tabular}




\begin{tabular}{|c|c|c|c|c|c|c|c|c|c|}
\hline $\begin{array}{c}\text { 10-year } \\
\text { actual } \\
\left(\mathrm{ft}^{3} / \mathrm{s}\right)\end{array}$ & $\begin{array}{c}\text { 10-year } \\
\text { rural } \\
\left(\mathrm{ft}^{3} / \mathrm{s}\right)\end{array}$ & $\begin{array}{c}25-y e a r \\
\text { actual } \\
\left(\mathrm{ft}^{3} / \mathrm{s}\right)\end{array}$ & $\begin{array}{c}\text { 25-year } \\
\text { rural } \\
\left(\mathrm{ft}^{3} / \mathrm{s}\right)\end{array}$ & $\begin{array}{c}\text { 50-year } \\
\text { actual } \\
\left(\mathrm{ft}^{3} / \mathrm{s}\right)\end{array}$ & $\begin{array}{c}\text { 50-year } \\
\text { rural } \\
\left(\mathrm{ft}^{3} / \mathrm{s}\right)\end{array}$ & $\begin{array}{c}100 \text {-year } \\
\text { actual } \\
\left(\mathrm{ft}^{3} / \mathrm{s}\right)\end{array}$ & $\begin{array}{c}100 \text {-year } \\
\text { rural } \\
\left(\mathrm{ft}^{3} / \mathrm{s}\right)\end{array}$ & $\begin{array}{c}500-y e a r \\
\text { actual } \\
\left(\mathrm{ft}^{3} / \mathrm{s}\right)\end{array}$ & $\begin{array}{c}\text { 500-year } \\
\text { rural } \\
\left(\mathrm{ft}^{3} / \mathrm{s}\right)\end{array}$ \\
\hline 7367 & 4080 & 8930 & 5850 & 9994 & 7410 & 10970 & 9210 & 12990 & 14600 \\
\hline 2736 & 1545 & 3385 & 2220 & 3892 & 2836 & 4419 & 3560 & 5738 & 5816 \\
\hline 1458 & 881 & 1899 & 1320 & 2256 & 1710 & 2636 & 2180 & 3622 & 3600 \\
\hline 1250 & 1070 & 1862 & 1590 & 2385 & 2060 & 2959 & 2610 & 4493 & 4280 \\
\hline 5494 & 5480 & 7386 & 7800 & 9033 & 9840 & 10900 & 12200 & 16260 & 19200 \\
\hline 1128 & 847 & 1395 & 1239 & 1609 & 1594 & 1836 & 2006 & 2423 & 3291 \\
\hline 4502 & 4020 & 6420 & 5760 & 8187 & 7310 & 10280 & 9090 & 16770 & 14500 \\
\hline 2882 & 1740 & 3628 & 2560 & 4224 & 3300 & 4854 & 4160 & 6474 & 6800 \\
\hline 2811 & 3060 & 4119 & 4410 & 5338 & 5610 & 6797 & 6980 & 11360 & 11100 \\
\hline 388 & 668 & 484 & 1040 & 553 & 1410 & 621 & 1880 & 774 & 3510 \\
\hline 4225 & 3840 & 6473 & 5510 & 8643 & 6990 & 11310 & 8690 & 20030 & 13800 \\
\hline 4183 & 3430 & 5074 & 4940 & 5677 & 6290 & 6230 & 7850 & 7357 & 12600 \\
\hline 3719 & 3470 & 5364 & 5000 & 6775 & 6350 & 8342 & 7920 & 12640 & 12600 \\
\hline 7839 & 9593 & 12080 & 13947 & 16550 & 17846 & 22520 & 22395 & 45190 & 36241 \\
\hline 10440 & 8092 & 15210 & 11526 & 19550 & 14499 & 24640 & 18017 & 40030 & 28327 \\
\hline 8661 & 5701 & 10720 & 8387 & 12340 & 10951 & 14020 & 13983 & 18270 & 23874 \\
\hline 7167 & 5089 & 9510 & 7291 & 11540 & 9277 & 13820 & 11645 & 20350 & 18755 \\
\hline 2783 & 2590 & 4550 & 4020 & 6459 & 5420 & 9050 & 7200 & 19140 & 13300 \\
\hline 1622 & 1540 & 1873 & 1983 & 2056 & 2348 & 2235 & 2647 & 2645 & 3476 \\
\hline 4192 & 3501 & 4721 & 4508 & 5053 & 5333 & 5343 & 6018 & 5894 & 7902 \\
\hline 3590 & 2270 & 3913 & 2918 & 4121 & 3452 & 4306 & 3889 & 4674 & 5097 \\
\hline 4195 & 2811 & 4539 & 3615 & 4767 & 4279 & 4975 & 4819 & 5403 & 6320 \\
\hline 89.8 & 205 & 318 & 411 & 673 & 607 & 1262 & 876 & 3987 & 1837 \\
\hline 485 & 729 & 2106 & 1551 & 5179 & 2386 & 11260 & 3583 & 49570 & 8164 \\
\hline 69.9 & 181 & 142 & 1072 & 232 & 3026 & 372 & 7003 & 1043 & 38288 \\
\hline 1167 & 1795 & 1441 & 2433 & 1660 & 2959 & 1891 & 3531 & 2488 & 5142 \\
\hline 8897 & 6940 & 9968 & 8480 & 10680 & 9696 & 11340 & 10974 & 12680 & 13982 \\
\hline 10680 & 8154 & 12280 & 10065 & 13390 & 11583 & 14460 & 13181 & 16800 & 17015 \\
\hline 2738 & 3898 & 3255 & 4786 & 3658 & 5478 & 4076 & 6194 & 5125 & 7844 \\
\hline 3153 & 11177 & 3823 & 13775 & 4341 & 15704 & 4874 & 17595 & 6195 & 22190 \\
\hline 420 & 1801 & 519 & 2218 & 594 & 2507 & 668 & 2771 & 845 & 3402 \\
\hline 1248 & 694 & 1416 & 1015 & 1541 & 1385 & 1667 & 1830 & 1966 & 3219 \\
\hline 779 & 628 & 993 & 919 & 1171 & 1253 & 1367 & 1656 & 1900 & 2912 \\
\hline 4432 & 2381 & 5024 & 3394 & 5431 & 4299 & 5813 & 5349 & 6630 & 8455 \\
\hline 5819 & 2867 & 6728 & 4086 & 7387 & 5176 & 8035 & 6441 & 9522 & 10197 \\
\hline 4786 & 3345 & 5770 & 4765 & 6459 & 6036 & 7112 & 7514 & 8518 & 11909 \\
\hline 1068 & 862 & 1341 & 1217 & 1542 & 1552 & 1740 & 1923 & 2193 & 3054 \\
\hline 1735 & 1061 & 2177 & 1479 & 2491 & 1868 & 2792 & 2293 & 3443 & 3576 \\
\hline 2011 & 1944 & 2869 & 2536 & 3657 & 3012 & 4588 & 3518 & 7455 & 4795 \\
\hline 1238 & 1631 & 1919 & 2143 & 2613 & 2556 & 3510 & 2997 & 6712 & 4120 \\
\hline
\end{tabular}




\section{Appendix 3}

Appendix 3. Plots of predicted and observed flood discharges. Predicted discharges are from calibrated simple imperviousness adjustment model. Observed are from appropriate U.S. Geological Survey rural regression equations.
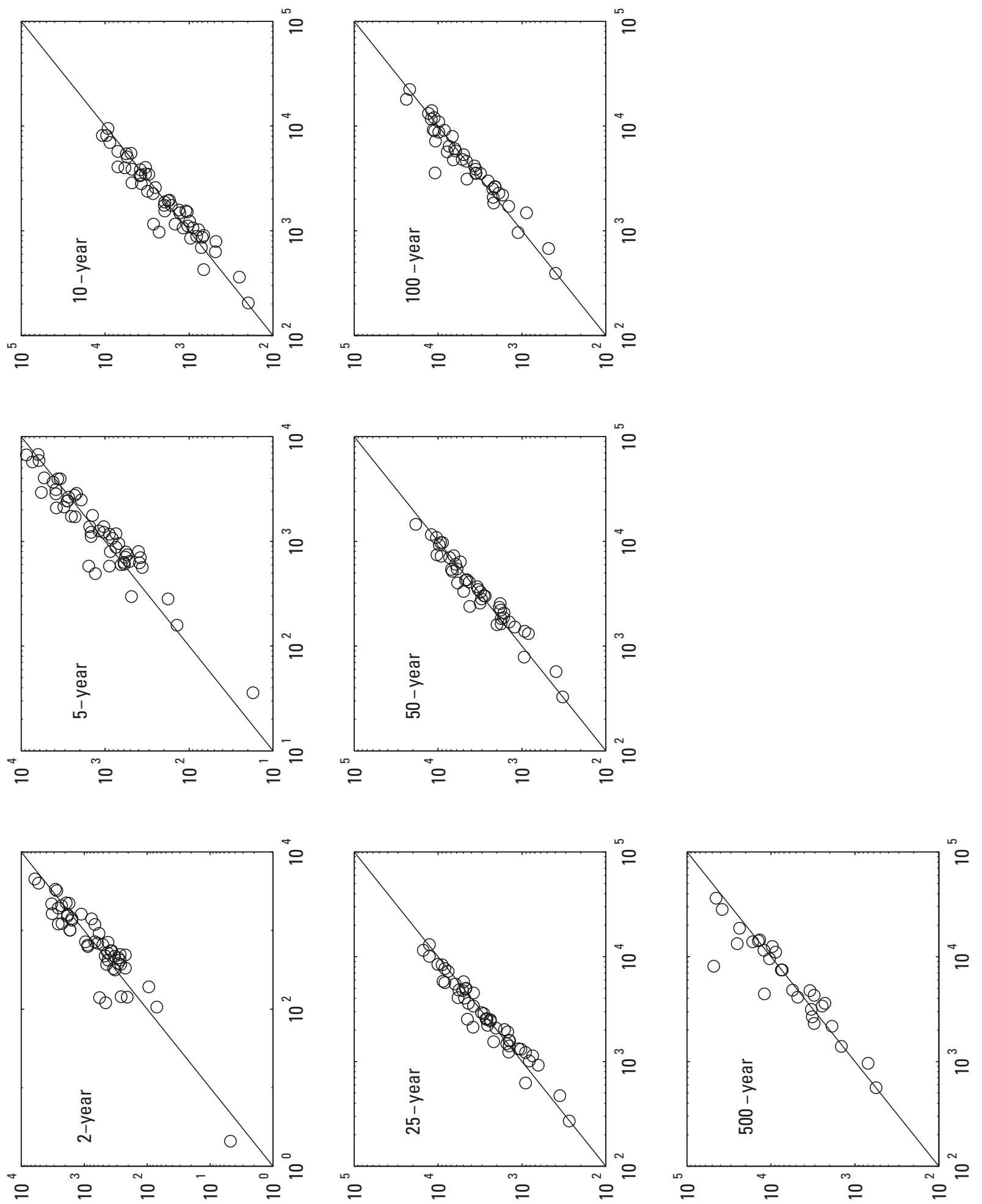

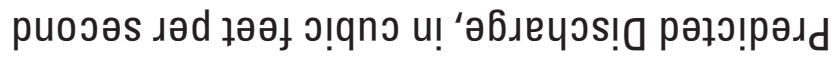




\section{Appendix 4}

Appendix 4. Calibrated (x) and smoothed (o) coefficient and exponents for the discharge adjustment models and return period.

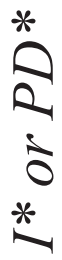

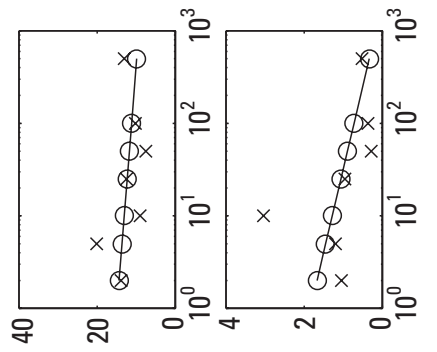

$u^{\star}$

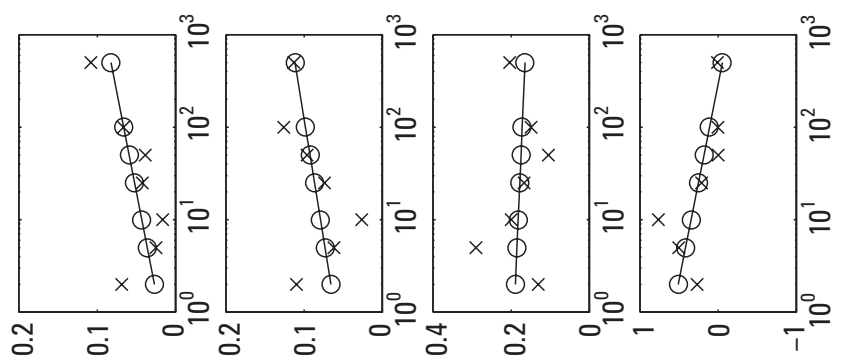

$u^{n}$
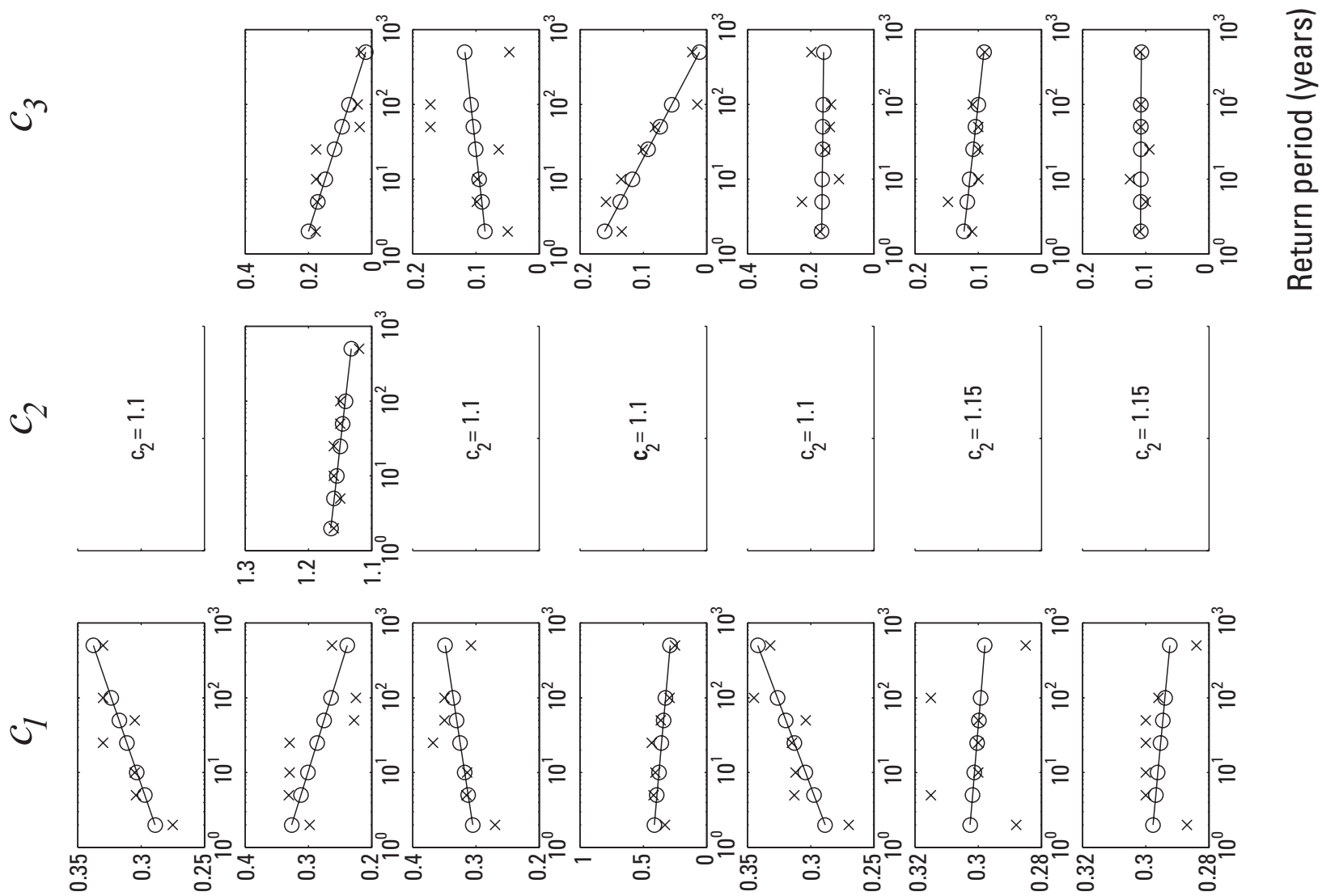

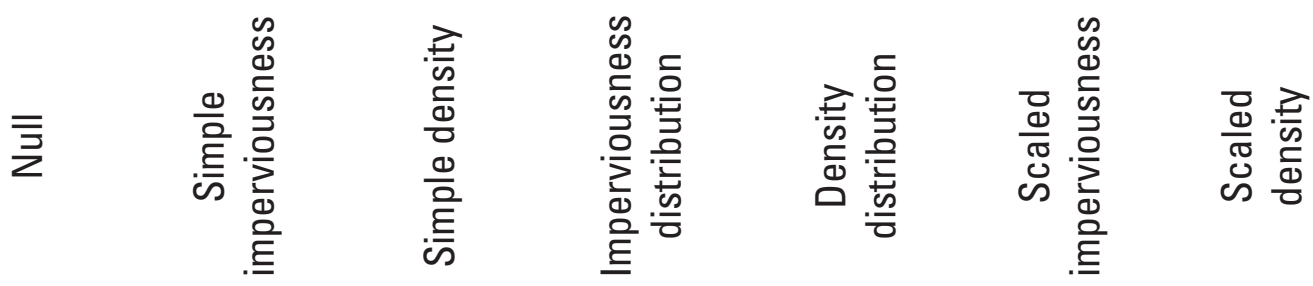




\section{Methods for Adjusting USGS Rural Regression Peak Discharges in an Urban Setting}

\section{Appendix 5}

Appendix 5. Watershed characteristics for 10 U.S. Geological Survay streamgages with localized urban equations.

[ $\mathrm{mi}^{2}$, square miles; $\mathrm{ft} / \mathrm{mi}$, feet per mile; \%, percent]

\begin{tabular}{|c|c|c|c|c|c|c|c|c|c|c|}
\hline $\begin{array}{l}\text { Streamgage } \\
\text { number }\end{array}$ & Streamgage name & State & $\begin{array}{l}\text { Area } \\
\left(\mathrm{mi}^{2}\right)\end{array}$ & $\begin{array}{l}\text { Slope } \\
\text { (ft/mi) }\end{array}$ & $\begin{array}{c}\text { Stor- } \\
\text { age } \\
(\%)\end{array}$ & $\begin{array}{c}\text { Imper- } \\
\text { vious } \\
\text { area } \\
(\%)\end{array}$ & $\begin{array}{c}\text { Forest } \\
\text { cover } \\
(\%)\end{array}$ & $\begin{array}{c}\text { Urban } \\
\text { area } \\
(\%)\end{array}$ & $\begin{array}{c}\text { Car- } \\
\text { bonate } \\
\text { area } \\
(\%)\end{array}$ & $\begin{array}{c}\text { Con- } \\
\text { trolled } \\
\text { area } \\
(\%)\end{array}$ \\
\hline 01393450 & $\begin{array}{l}\text { ELIZABETH R AT URSINO LAKE } \\
\text { AT ELIZABETH NJ }\end{array}$ & NJ & 17.6 & 22.4 & 1.6 & 41.9 & & & & \\
\hline 01394500 & RAHWAY R NR SPRINGFIELD NJ & NJ & 25.3 & 30.6 & 1.3 & 22.2 & & & & \\
\hline 01407705 & SHARK R NR NEPTUNE CITY NJ & NJ & 9.8 & 29.4 & 17.6 & 9.0 & & & & \\
\hline 01407760 & $\begin{array}{l}\text { JUMPING BROOK NR NEPTUNE } \\
\text { CITY NJ }\end{array}$ & NJ & 6.3 & 35.2 & 8.4 & 10.1 & & & & \\
\hline 01465798 & $\begin{array}{l}\text { POQUESSING C AT GRANT AVE } \\
\text { AT PHILADELPHIA PA }\end{array}$ & PA & 21.1 & & & & 16.6 & 66.5 & 1.1 & 14.9 \\
\hline 01467048 & $\begin{array}{l}\text { PENNYPACK C AT LOWER } \\
\text { RHAWN ST BDG, PHILA PA }\end{array}$ & PA & 50.0 & & & & 29.2 & 59.4 & 1.5 & 6.1 \\
\hline 01467087 & $\begin{array}{l}\text { FRANKFORD C AT CASTOR AVE, } \\
\text { PHILADELPHIA PA }\end{array}$ & PA & 29.8 & & & & 17.4 & 77.2 & 0.0 & 0.0 \\
\hline 03049800 & LITTLE PINE C NR ETNA PA & PA & 5.7 & & & & 79.8 & 8.2 & 0.0 & 0.0 \\
\hline 04087204 & OAK C AT S MILWAUKEE WI & WI & 25.4 & & & 16.8 & & & & \\
\hline 04087220 & ROOT R NR FRANKLIN WI & WI & 49.8 & & & 19.6 & & & & \\
\hline
\end{tabular}




\section{Appendix 6}

Appendix 6. Rural and urban discharges, in cubic feet per second for 10 U.S. Geological Survey streamgages with localized urban equations.

[Entries in italics were not available directly from the regression equations and were determined from log-normal extrapolation.]

\begin{tabular}{|c|c|c|c|c|c|c|c|c|c|}
\hline \multirow{2}{*}{$\begin{array}{l}\text { Streamgage } \\
\text { number }\end{array}$} & \multirow{2}{*}{ Streamgage name } & \multirow{2}{*}{ State } & \multicolumn{7}{|c|}{ Return Period (years) } \\
\hline & & & 2 & 5 & 10 & 25 & 50 & 100 & 500 \\
\hline \multicolumn{10}{|c|}{ Urban Discharges } \\
\hline 01394500 & RAHWAY R NR SPRINGFIELD NJ & $\mathrm{NJ}$ & 1,452 & 2,088 & 2,784 & 3,580 & 4,219 & 5,016 & 7,120 \\
\hline 01407760 & JUMPING BROOK NR NEPTUNE CITY NJ & $\mathrm{NJ}$ & 166 & 254 & 350 & 476 & 584 & 715 & 1,075 \\
\hline 01465798 & $\begin{array}{l}\text { POQUESSING C AT GRANT AVE AT } \\
\text { PHILADELPHIA PA }\end{array}$ & PA & 2,739 & 3,984 & 4,845 & 5,970 & 7,009 & 8,140 & 11,180 \\
\hline 01467048 & $\begin{array}{l}\text { PENNYPACK C AT LOWER RHAWN ST } \\
\text { BDG, PHILADELPHIA PA }\end{array}$ & PA & 5,019 & 7,095 & 8,503 & 10,312 & 11,971 & 13,742 & 18,381 \\
\hline 04087204 & OAK C AT S MILWAUKEE WI & WI & 941 & 1,301 & 1,585 & 1,912 & 2,207 & 2,440 & 2,991 \\
\hline 04087220 & ROOT R NR FRANKLIN WI & WI & 1,847 & 2,518 & 3,062 & 3,691 & 4,266 & 4,716 & 5,777 \\
\hline \multicolumn{10}{|c|}{ Rural Discharges } \\
\hline 01393450 & $\begin{array}{l}\text { ELIZABETH R AT URSINO LAKE AT } \\
\text { ELIZABETH NJ }\end{array}$ & NJ & 550 & 863 & 1,217 & 1,672 & 2,104 & 2,674 & 4,343 \\
\hline 01394500 & RAHWAY R NR SPRINGFIELD NJ & $\mathrm{NJ}$ & 903 & 1,411 & 1,993 & 2,713 & 3,386 & 4,287 & 6,912 \\
\hline 01407705 & SHARK R NR NEPTUNE CITY NJ & NJ & 91 & 152 & 220 & 313 & 405 & 517 & 850 \\
\hline 01407760 & JUMPING BROOK NR NEPTUNE CITY NJ & NJ & 97 & 159 & 229 & 327 & 421 & 540 & 896 \\
\hline 01465798 & $\begin{array}{l}\text { POQUESSING C AT GRANT AVE AT } \\
\text { PHILADELPHIA PA }\end{array}$ & PA & 1,132 & 2,089 & 2,879 & 4,051 & 5,220 & 6,626 & 11,062 \\
\hline 04087204 & OAK C AT S MILWAUKEE, WI & WI & 454 & 651 & 792 & 966 & 1,095 & 1,219 & 1,514 \\
\hline 04087220 & ROOT R NR FRANKLIN, WI & WI & 796 & 1,127 & 1,360 & 1,645 & 1,859 & 2,062 & 2,544 \\
\hline
\end{tabular}



